DOE/NV-325-Rev. 6-01

June 2006

\title{
Nevada Test Site Waste Acceptance Criteria
}

\author{
Prepared by the
}

U. S. Department of Energy

National Nuclear Security Administration

Nevada Site Office

Waste Management Division

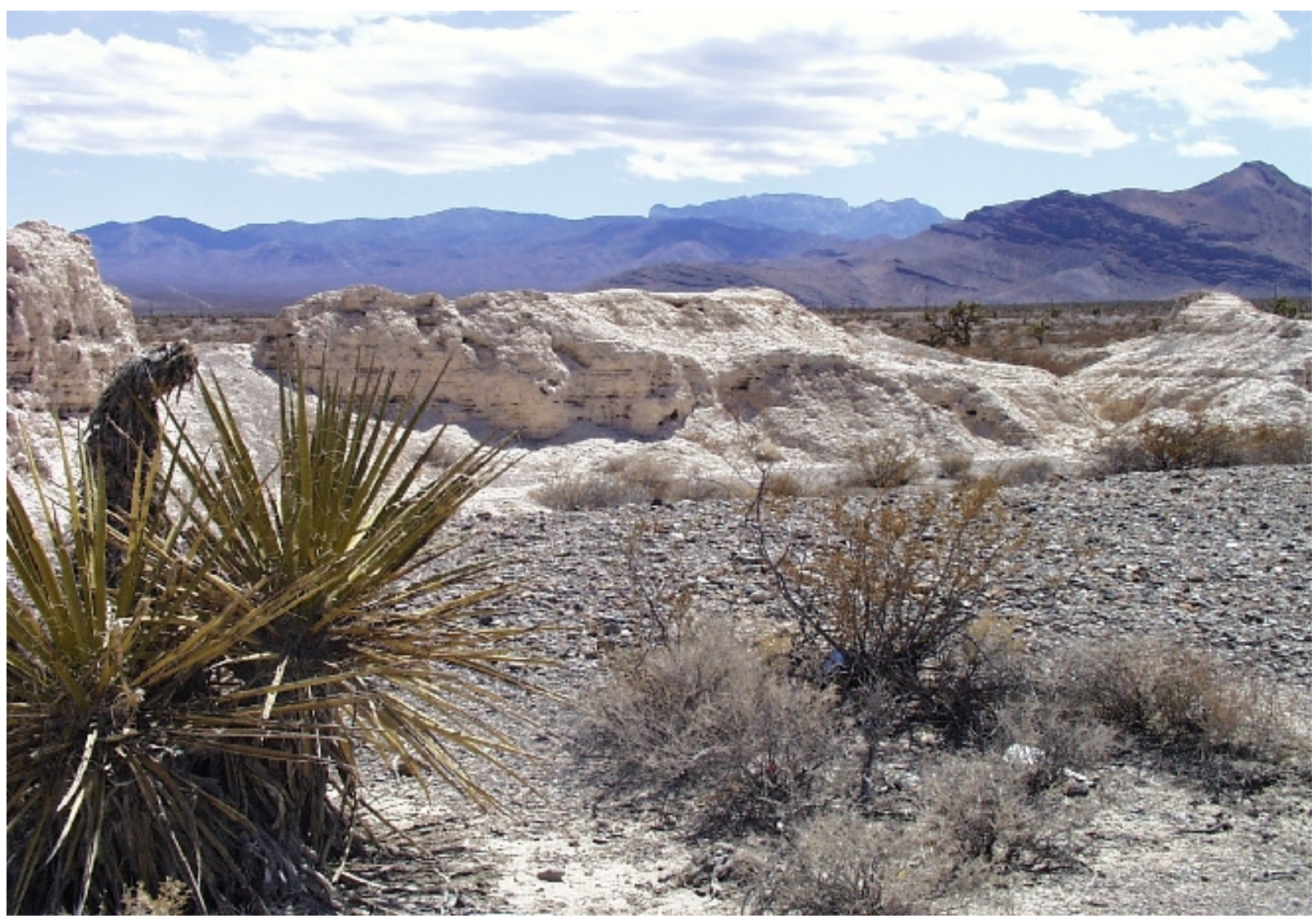




\section{Disclaimer Notice}

Reference herein to any specific commercial product, process, or service by trade name, trade mark, manufacturer, or otherwise does not necessarily constitute or imply its endorsement, recommendation, or favoring by the United States Government or any agency thereof or its contractors or subcontractors.

Available for sale to the public, in paper, from:

U.S. Department of Commerce

National Technical Information Service

5285 Port Royal Road

Springfield, VA 22161

Phone: (800) 553-6847

Fax: (703) 605-6900

E-mail: orders@ntis.fedworld.gov

Online Ordering: http://www.ntis.gov/ordering.htm

Available electronically at http://www.osti.gov/bridge

Available for a processing fee to the U.S. Department of Energy and its contractors, in paper, from:

U.S. Department of Energy

Office of Scientific and Technical Information

P.O. Box 62

Oak Ridge, TN 37831-0062

Phone: (865) 576-8401

Fax: (865) 576-5728

E-mail: reports@adonis.osti.gov

Photograph on front cover: Desert National Wildlife Range landscape located southeast of Mercury, Nevada. 


\section{Nevada Test Site Waste Acceptance Criteria}

NTSWAC (Rev. 6-01)

June 2006

Prepared by the

U. S. Department of Energy

National Nuclear Security Administration

Nevada Site Office

Waste Management Division 
This page intentionally left blank. 


\section{Approval Signatures}

To the best of our knowledge, this document is correct and the process and criteria stated within meet the U.S. Department of Energy and appropriate federal regulation requirements.

Approved and

Issued by:

Original Signed by Stephen A. Mellington

Date: $\quad 09 / 26 / 05$

Assistant Manager

Environmental Management Nevada Site Office

National Nuclear Security Administration

U.S. Department of Energy

Concur:

Original Signed by Kathy A. Carlson

Date: $09 / 26 / 05$

Manager

Nevada Site Office

National Nuclear Security Administration

U.S. Department of Energy

Concur: $\quad$ Original Signed by E. Frank DiSanza

Date: $\quad 09 / 26 / 05$

\section{Director}

Waste Management Division

Nevada Site Office

National Nuclear Security Administration

U.S. Department of Energy

Concur: $\quad$ Original Signed by E. Frank DiSanza

Date: $09 / 26 / 05$

Mixed Low-Level Waste Program Manager

Nevada Site Office

National Nuclear Security Administration

U.S. Department of Energy

Concur: $\quad$ Original Signed by Jhon T. Carilli

Date: $09 / 26 / 05$

Low-Level Waste Operations Team Leader

Waste Management Division

Nevada Site Office

National Nuclear Security Administration

U.S. Department of Energy

Concur: $\quad$ Original Signed by Gary L. Pyles

Date: $09 / 26 / 05$

Radioactive Waste Acceptance Program Task Manager

Waste Management Division

Nevada Site Office

National Nuclear Security Administration

U.S. Department of Energy 


\section{NTSWAC Revision History}

\begin{tabular}{lcl}
\hline Date & Pages Changed & Revision \\
\hline $09 / 1996$ & All & Rev. 0 \\
$08 / 1997$ & All & Rev. 1 \\
$05 / 1999$ & All & Rev. 2 \\
$02 / 2000$ & i, vi, 3-5, Ref-1 & Rev. 2, DCN DOE/NV-325-03-01 \\
$11 / 2000$ & All & Rev. 3 \\
$01 / 2002$ & All & Rev. 4 \\
$10 / 2003$ & 3-8, 3-10, Appendix G & Rev. 5-01, DOE/NV-325-Rev 5-DCN-05-01 \\
$07 / 2005$ & All & Rev. 5 \\
$10 / 2005$ & 6-4, B-1, E-1, E-3, G-1, H-2, & \\
$06 / 2006$ & Ref-4
\end{tabular}




\section{Table of Contents}

Acronyms vii

1.0 Radioactive Waste Management at the Nevada Test Site ........................................ 1-1

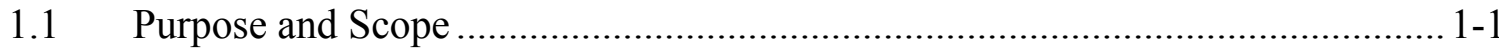

1.2 Policy .................................................................................................. $1-1$

1.2.1 NNSA/NSO Policies ................................................................. 1-1

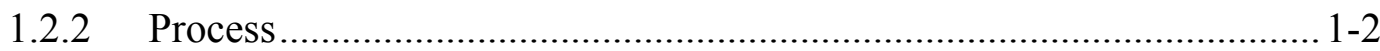

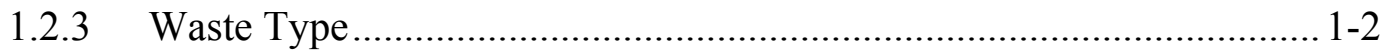

1.2.4 Regulators and Stakeholders ....................................................... 1-2

1.3 Requirements .................................................................................... 1-2

1.4 Responsibilities..................................................................................... $1-2$

1.4.1 Manager ................................................................................ 1-2

1.4.2 Assistant Manager for Environmental Management (AMEM)............. 1-3

1.4.3 Director, Waste Management Division ................................................... 1-3

1.4.4 Low-Level Operations Waste Team Lead........................................... 1-3

1.4.5 Mixed Low-Level Waste Program Manager......................................... 1-3

1.4.6 Radioactive Waste Acceptance Program (RWAP) Task Manager ........ 1-3

1.4.7 RWAP Manager ............................................................................ 1-3

1.4.8 RWAP Personnel......................................................................... 1-3

$2.0 \quad$ Approval Process ..................................................................................... 2-1

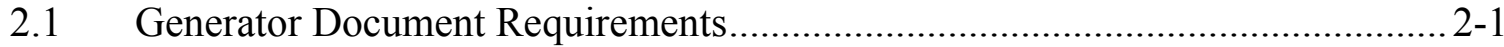

2.1.1 Waste Profiles................................................................................ 2-1

2.1.2 Waste Certification Plan................................................................... 2-1

2.1.3 NTSWAC Implementation Crosswalk .................................................. 2-1

2.1.4 Certification Personnel List ................................................................. 2-2

2.1.5 Document and Personnel Changes .................................................... 2-2

2.2 RWAP Review................................................................................ 2-2

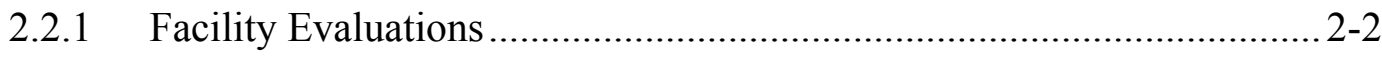

2.2.1.1 Biennial Audit ....................................................................... 2-3

2.2.1.2 Surveillance........................................................................ 2-3

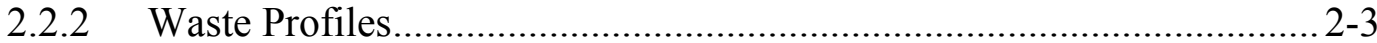

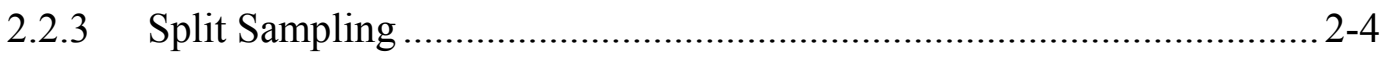

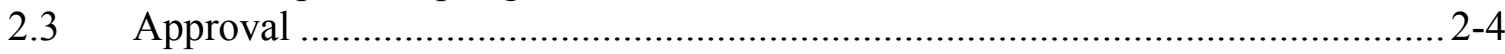

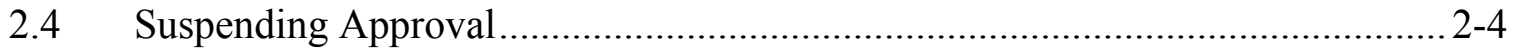

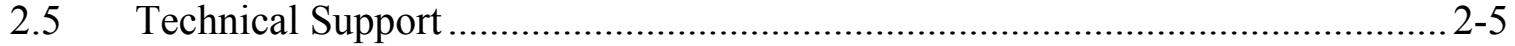

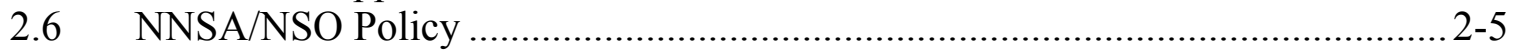

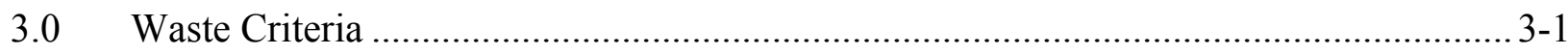

3.1 General Waste Form Criteria .............................................................. 3-1

3.1.1 Transuranics ....................................................................... $3-1$ 
3.1.2 Radionuclide Content or Concentration ............................................ 3-1

3.1.3 Commercial Greater-Than-Class-C Waste.............................................. 3-1

3.1.4 Hazardous Waste ............................................................................. 3-2

3.1.5 Free Liquids.............................................................................. $3-3$

3.1.6 Particulates ............................................................................... 3-3

3.1.7 Gases .................................................................................. $3-3$

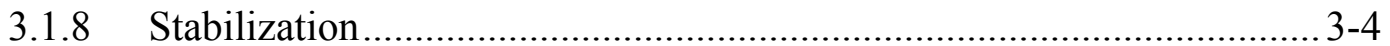

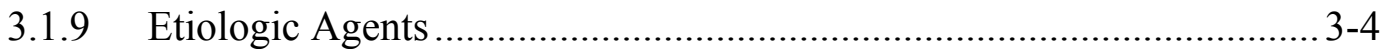

3.1.10 Chelating Agents .......................................................................... 3-4

3.1.11 Polychlorinated Biphenyls (PCBs) ................................................ 3-4

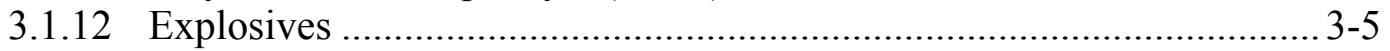

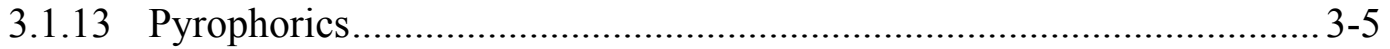

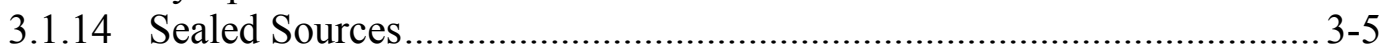

3.1.15 Low-Level Waste Containing Asbestos ............................................. 3-6

3.1.16 Radioactive Animal Carcasses .......................................................... 3-7

3.1.17 Low-Level Beryllium Waste .......................................................... 3-7

3.1.18 'Classified Waste' .......................................................................... 3-7

3.2 Waste Package Criteria ............................................................................. 3-7

3.2.1 Nuclear Criticality Safety ............................................................. 3-8

3.2.2 Package Activity Limitations ......................................................... 3-8

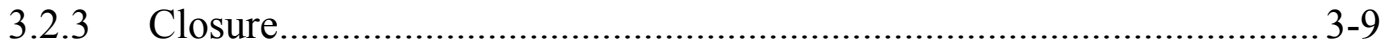

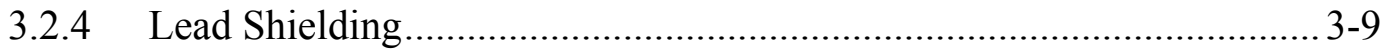

3.2.5 Strength .................................................................................. $3-9$

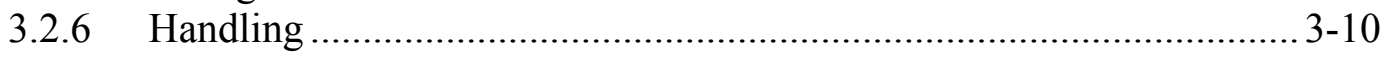

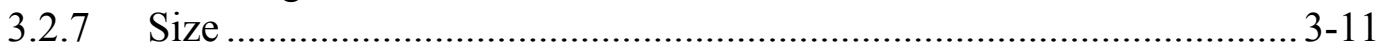

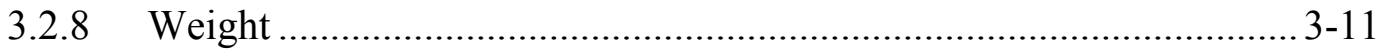

3.2.9 Loading (Void Space) ................................................................... 3-12

3.2.10 Package Protection ....................................................................... 3-12

3.2.11 Marking and Labeling ................................................................ 3-12

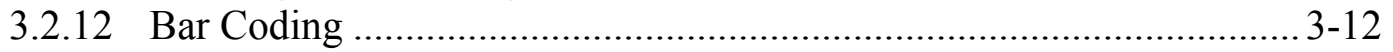

3.2.13 Contamination Levels.............................................................. 3-12

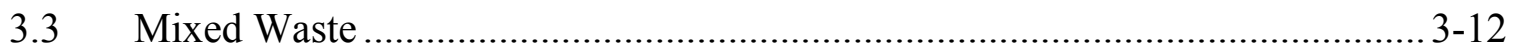

3.3.1 Acceptable Hazardous Waste Numbers ............................................ 3-13

3.3.2 Mixed Waste Treatment Notification................................................ 3-13

3.3.3 Mixed Waste Profiles .................................................................... 3-13

3.3.4 Land Disposal Restrictions.......................................................... 3-13

3.3.4.1 Determinations of Equivalent Technology (DET) ................ 3-14

3.3.5 Waste Form Criteria/Prohibited Items ............................................. 3-14

3.3.5.1 Free Liquids ................................................................. 3-14

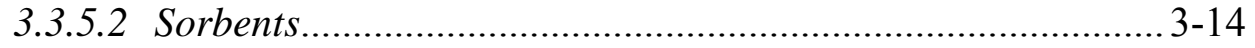

3.3.6 MW Package Criteria .................................................................... 3-15

3.3.6.1 Marking and Labeling ................................................... 3-15

3.3.6.2 Void Space ....................................................................... 3-16

3.3.6.3 Package Protection .......................................................... 3-16

3.3.7 Analytical Data .................................................................... 3-16

3.3.8 MW Verification ......................................................................... 3-16 


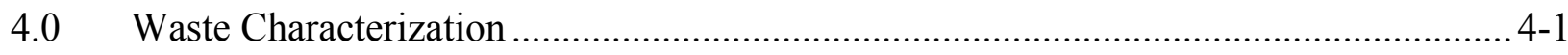

4.1 Process Knowledge ........................................................................ 4-1

4.2 Sampling and Analysis .......................................................................... 4-2

4.2.1 Data Validation...................................................................... 4-3

5.0 Quality Assurance Requirements for Waste Certification Program ............................5-1

5.1 Program ................................................................................................ $5-1$

5.2 Personnel Training and Qualification ....................................................... 5-2

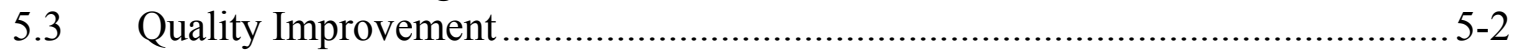

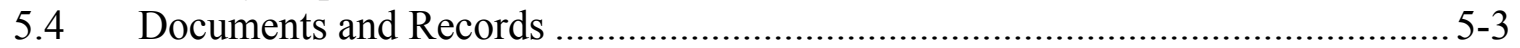

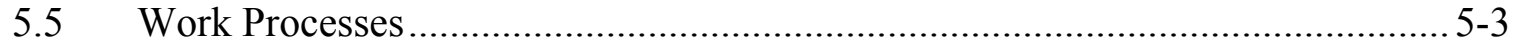

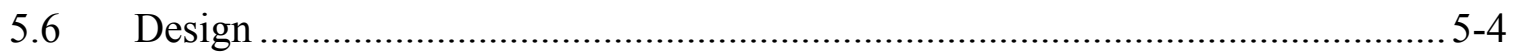

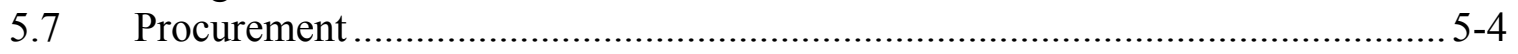

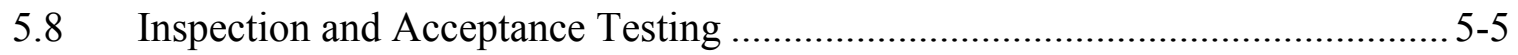

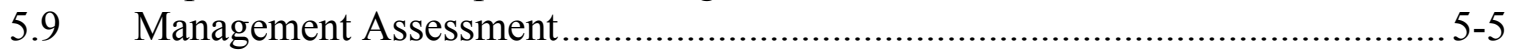

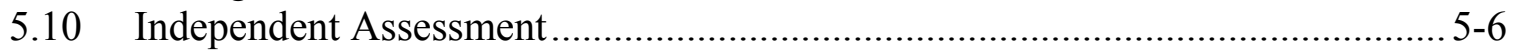

6.0 Waste Transportation and Receipt Information .............................................. 6-1

6.1 Shipment Scheduling and Limitations .......................................................

6.2 Shipping Arrangements ......................................................................... $6-1$

6.2.1 Waste Receipt and Handling at NTS ............................................. 6-2

6.2.2 Consignment of Shipments ...................................................... 6-3

6.2.3 Receiving Hours ..................................................................... 6-3

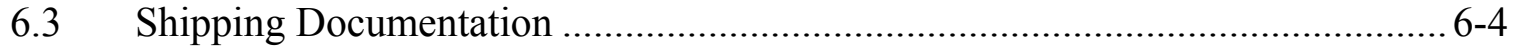

6.3.1 Accountable or Special Nuclear Material Shipments............................ 6-4

6.3.2 DOT Regulated Shipments........................................................ 6-4

6.3.3 PSDR Submittal ........................................................................ 6-4

6.3.4 Additional Certification Statements ...................................................... 6-5

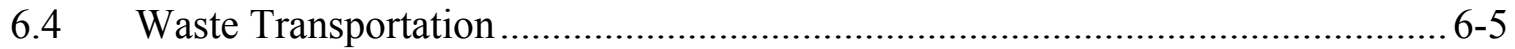

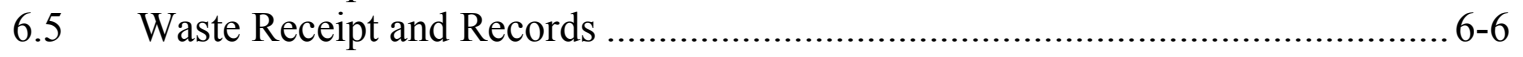

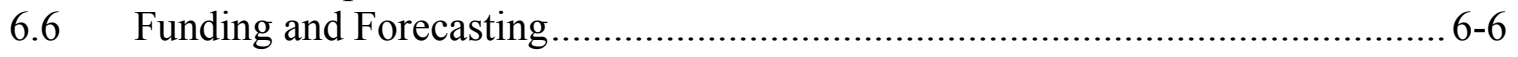

6.7 Disposition of Noncompliant Conditions ................................................ 6-6

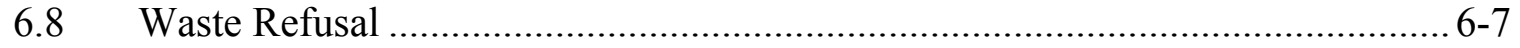

Appendix A - Waste Process Flow Diagram ................................................................ A-1

Appendix B - Plutonium Equivalent Gram (PE-g) Radionuclide Conversion Factors.............. B-1 | 


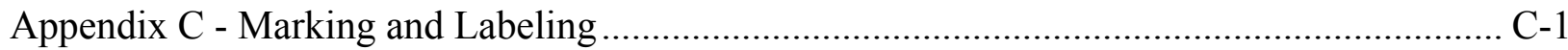

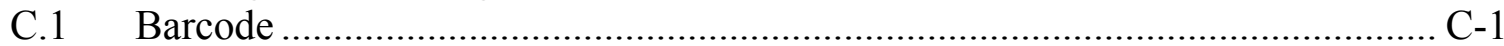

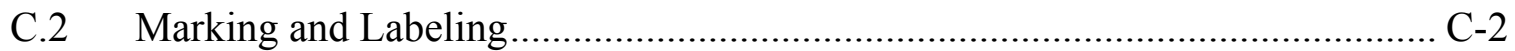

C.3 Generator Waste Stream and Shipment Codes ............................................... C-4

C.4 NTS Advance Shipment Notification ........................................................... C-5

Appendix D -Package Storage and Disposal Request …………………………………....... D-1

| Appendix E - Radiological Waste Characterization and Reporting Requirements ......................E-1

E.1 Radionuclide Reporting ……………….......................................................

E.2 Waste Profile Instructions............................................................................

E.3 Radiological Characterization Methods...........................................................

E.4 Determination of Waste Volume _...................................................................

E.5 Examples of Waste Characterization Documentation ...........................................

E.6 Radiological Characterization Flow Diagram Overview.....................................E-6

E.7 Fissile Material Limits ...................................................................................

Appendix F - Requirements for Intermodal (Roll-off boxes) LLW Disposal..............................F-1

Appendix G - Mixed Waste Forms …………………….................................................. G-1

| G.1 Pre-Treatment Notification Form for Mixed Waste …................................................. G-1

G.2 Mixed Waste Profile Annual Certification Example ....................................................... G-3

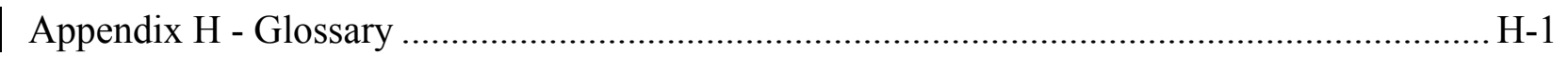

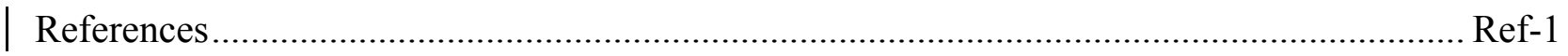

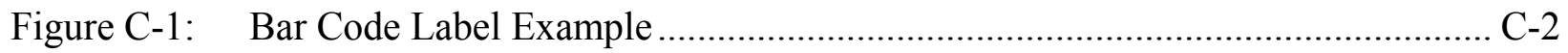

Figure C-2: Package Certification Label...................................................................... C-3

Figure E-1: Radiological Characterization Flow Diagram …………………………..............

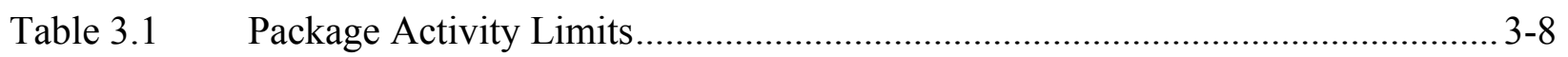

| Table B-1 Anaylical Results .................................................................................. 4-5

Table E-1: $\quad$ Radionuclide Action Levels For Waste Characterization And Reporting............E-2

Table E-2: Exempt Radionuclides .................................................................................

Table E.3: Calculation $O{ }^{235} \mathrm{U}$ Fissile Gram Equivalence And Effective ${ }^{235} \mathrm{U}$ Enrichment

For LLW Packages ..................................................................................

Table E.4: Allowable Package Fissile Loadings For Various Package Steel Weights .......E-11

Table E.5: Criticality Safety Restrictions For The Use Of The Fissile Limits In

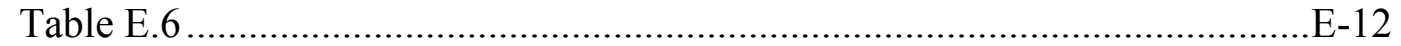

Table E.6: Maximum Grams Of ${ }^{235} \mathrm{U}$ As A Function Of Enrichment (controls as specified in

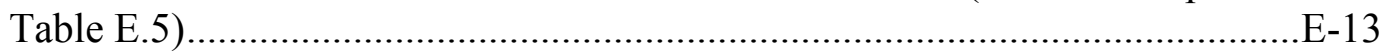




\section{Acronyms}

ACM Asbestos-Containing material

ALARA As Low as Reasonably Achievable

ALLW Asbestiform Low-Level Waste

AMEM Assistant Manager for Environmental Management

BN Bechtel Nevada

$\mathrm{Bq} \quad$ Becquerels

CAR Corrective Action Request

CFR Code of Federal Regulations

$\mathrm{Ci} \quad$ Curie

CSE Criticality Safety Evaluation

DET Determination of Equivalent Technology

DOE U.S. Department of Energy

DOT U.S. Department of Transportation

DQO Data Quality Objectives

EPA U.S. Environmental Protection Agency

ETA Estimated Time of Arrival

FGE Fissile Gram Equivalence

HEPA High-Efficiency Particulate Arresting

HRI Human Readable Interpretation

LDR Land Disposal Restrictions

LLD Lower Limit of Detection

LLW Low-Level Waste

MC\&A Materials Control and Accountability

M\&TE Measuring and Test Equipment

MW Mixed Waste

MWP Mixed Waste Profile

NDEP Nevada Department of Conservation and Natural Resources, Division of Environmental Protection

NIC NTSWAC Implementation Crosswalk

NNSA/NSO National Nuclear Security Administration Nevada Site Office

NRC U.S. Nuclear Regulatory Commission

NTS Nevada Test Site

NTSWAC Nevada Test Site Waste Acceptance Criteria 


\section{Acronyms (continued)}

PCB Polychlorinated Biphenyls

PCL Package Certification Label

PE-g Plutonium Equivalent Gram

PK Process Knowledge

PSDR Package Storage and Disposal Request

QA Quality Assurance

QAP Quality Assurance Plan

RCRA Resource Conservation and Recovery Act

RTR Real-Time-Radiography

RWAP Radioactive Waste Acceptance Program

RWMC Radioactive Waste Management Complex

SSC Structures, Systems, and Components

SW-846 EPA Document SW-846, "Test Methods for Evaluation Solid Waste, Physical/Chemical Methods"

TCLP Toxicity Characteristic Leaching Procedure

TRU Transuranic

WAC Waste Acceptance Criteria

WAP Waste Analysis Plan

WARP Waste Acceptance Review Panel

WATS Waste Generator Assistance and Technical Support

WCO Waste Certification Official

WCPP Waste Certification Program Plan

WMD Waste Management Division

WP Waste Profile 


\section{0}

\section{Radioactive Waste Management at the Nevada Test Site}

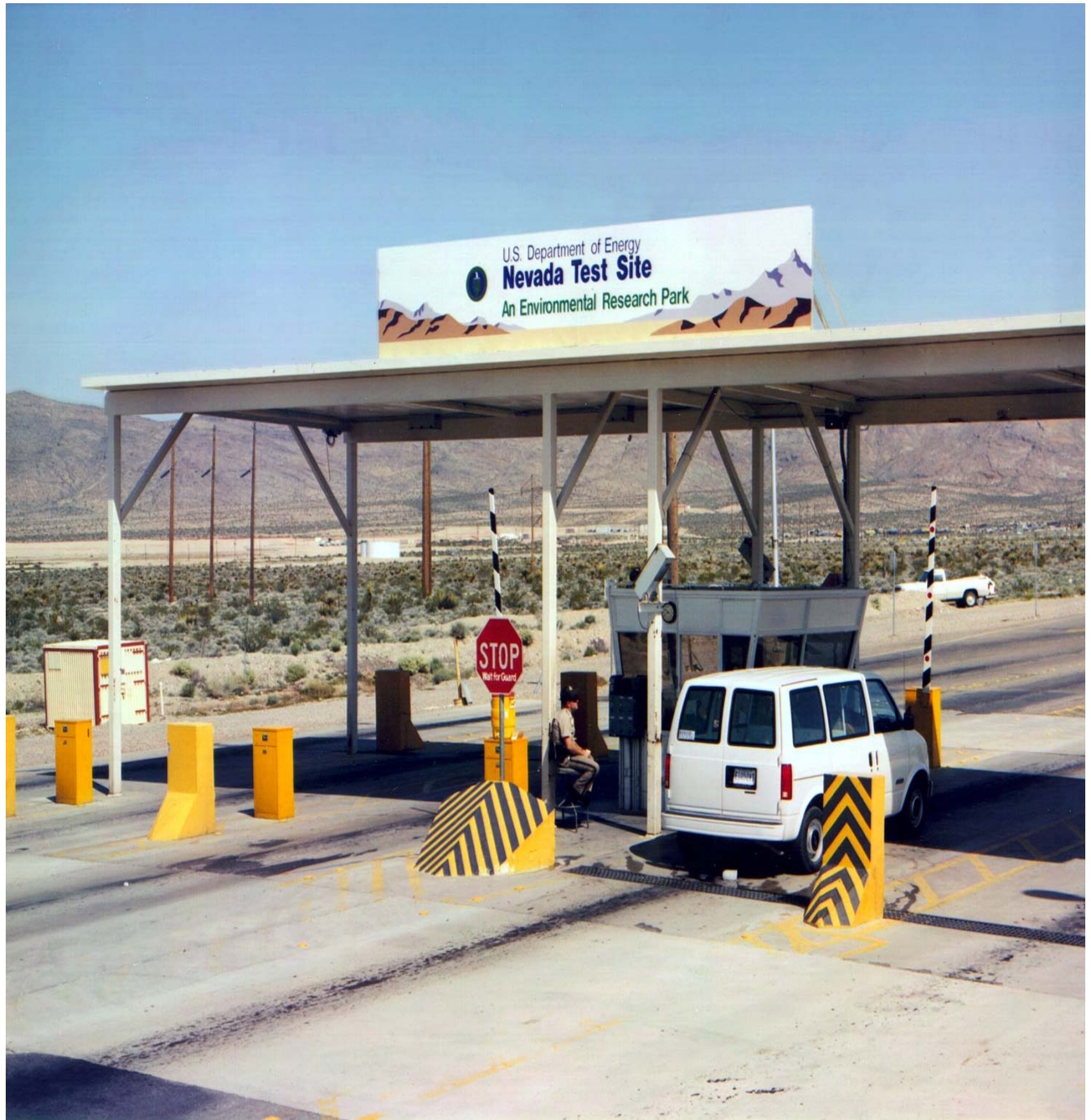

Gate 1 - Mercury, Nevada 
This page intentionally left blank. 


\subsection{Radioactive Waste Management at the Nevada Test Site}

\subsection{Purpose and Scope}

This document establishes the U.S. Department of Energy (DOE), National Nuclear Security Administration Nevada Site Office (NNSA/NSO) waste acceptance criteria (WAC). The WAC provides the requirements, terms, and conditions under which the Nevada Test Site (NTS) will accept low-level radioactive (LLW) and mixed waste (MW) for disposal. It includes requirements for the generator waste certification program, characterization, traceability, waste form, packaging, and transfer. The criteria apply to radioactive waste received at the NTS Area 3 and Area 5 Radioactive Waste Management Complex (RWMC) for storage or disposal. "Storage" in this document refers to the Area 5 RWMC classified units. The glossary defines the terms "storage" and "classified waste" as they are used in this document.

The NNSA/NSO and support contractors are available to assist you in understanding or interpreting this document. For assistance, please call NNSA/NSO Waste Management Division (WMD): phone (702) 295-0844, fax (702) 295-1153.

\subsection{Policy}

\subsubsection{NNSA/NSO Policies}

- $\quad$ ensure safe and compliant storage and disposal of radioactive waste; be consistent with the current revision of all applicable federal, state, and local regulations;

- $\quad$ protect the environment, personnel, and public from chemical and radiological hazards in accordance with Title 40 Code of Federal Regulations (CFR), the Resource Conservation and Recovery Act (RCRA); Title 10 CFR 835, "Occupational Radiation Protection"; DOE Order 435.1, "Radioactive Waste Management"; and state of Nevada and applicable U.S. Department of Transportation (DOT) regulations;

- ensure that present and future radiation exposures are kept as low as reasonably achievable (ALARA) and do not exceed the radiation protection standards established in Title 10 CFR 835, "Occupational Radiation Protection"; and

- ensure that Quality Assurance (QA) programs are established and implemented to fulfill the requirements of DOE Order 435.1, "Radioactive Waste Management"; Title 10 CFR 830.122, "Quality Assurance"; and DOE Order 414.1C, "Quality Assurance.” 


\subsubsection{Process}

Waste will be accepted from generators approved by NNSA/NSO. The approval process is described in Section 2.0.

\subsubsection{Waste Type}

LLW and MW will be accepted for disposal at the NTS. However, to verify the current acceptance status of waste types, please contact NNSA/NSO WMD.

\subsubsection{Regulators and Stakeholders}

NNSA/NSO will facilitate appropriate oversight by state agencies and support the involvement of the stakeholders. Where appropriate, to the extent possible, and in accordance with applicable NNSA/NSO authority, NNSA/NSO will provide regulatory agencies and stakeholders access to information related to Nevada Test Site Waste Acceptance Criteria (NTSWAC) activities, including waste characterization data, from all generators. Upon request by such parties, arrangements may be made to observe NTSWAC-related facility evaluations and participate in other activities such as NTSWAC revisions.

\subsection{Requirements}

Requirements are identified by "shall" or "must." The source of the requirement is identified by a superscript number which corresponds to the reference list. Statements not identified in this manner are provided as guidance. Section 2.0 requirements do not have corresponding references because the approval process is NNSA/NSO policy. Section 5.0 requirements are written in accordance with DOE Order 414.1, "Quality Assurance"; Title 10 CFR 830.122, "Quality Assurance"; and NNSA/NSO Policy unless otherwise noted by superscript.

\subsection{Responsibilities}

The following offices and personnel have responsibilities for management and acceptance of radioactive waste at the NTS. The offices identified are within the NNSA/NSO, unless otherwise stated.

\subsubsection{Manager}

Responsibilities and authorities as assigned in DOE Order 435.1. 


\subsubsection{Assistant Manager for Environmental Management (AMEM)}

Responsibilities and authorities as assigned in DOE Order 435.1. Responsible for the NNSA/NSO Radioactive Waste Management Program (RWAP) according to DOE Manual NV M 435.1-1, "Radioactive Waste Management Manual." Provides approval to waste generators to dispose or store radioactive waste at the NTS and grants any deviations from the requirements of this document. Responsible for suspension of any generator. May delegate his/her responsibilities except for approval and suspension.

\subsubsection{Director, Waste Management Division}

Responsible for radioactive waste management operation of the Areas 3 and 5 RWMC in compliance with applicable DOE Orders and federal and state regulations. Develop, implement, and maintain the NTSWAC.

\subsubsection{Low-Level Operations Waste Team Lead}

Responsible for management of radioactive waste disposal operations at NNSA/NSO, and implementation of the RWAP program to ensure compliance with the NTSWAC, DOE Orders, and federal regulations.

\subsubsection{Mixed Low-Level Waste Program Manager}

Responsible for the management of MW disposal operations at NNSA/NSO.

\subsubsection{Radioactive Waste Acceptance Program Task Manager}

Responsible for interfacing with waste generators regarding RWAP program criteria and activities, scheduling facility evaluations of waste generator programs, initiating recommendations to the AMEM regarding the status of waste generator programs, and maintaining RWAP quality records as defined by RWAP instructions.

\subsubsection{RWAP Manager}

Responsible for coordinating and managing daily activities of the RWAP program and RWAP personnel.

\subsubsection{RWAP Personnel}

Responsible for development, implementation, and maintenance of RWAP program documents (i.e., NTSWAC, instructions, checklists, etc.), and for providing guidance to generators shipping radioactive waste to the NTS. 
This page intentionally left blank. 


\section{0}

\section{Approval Process}

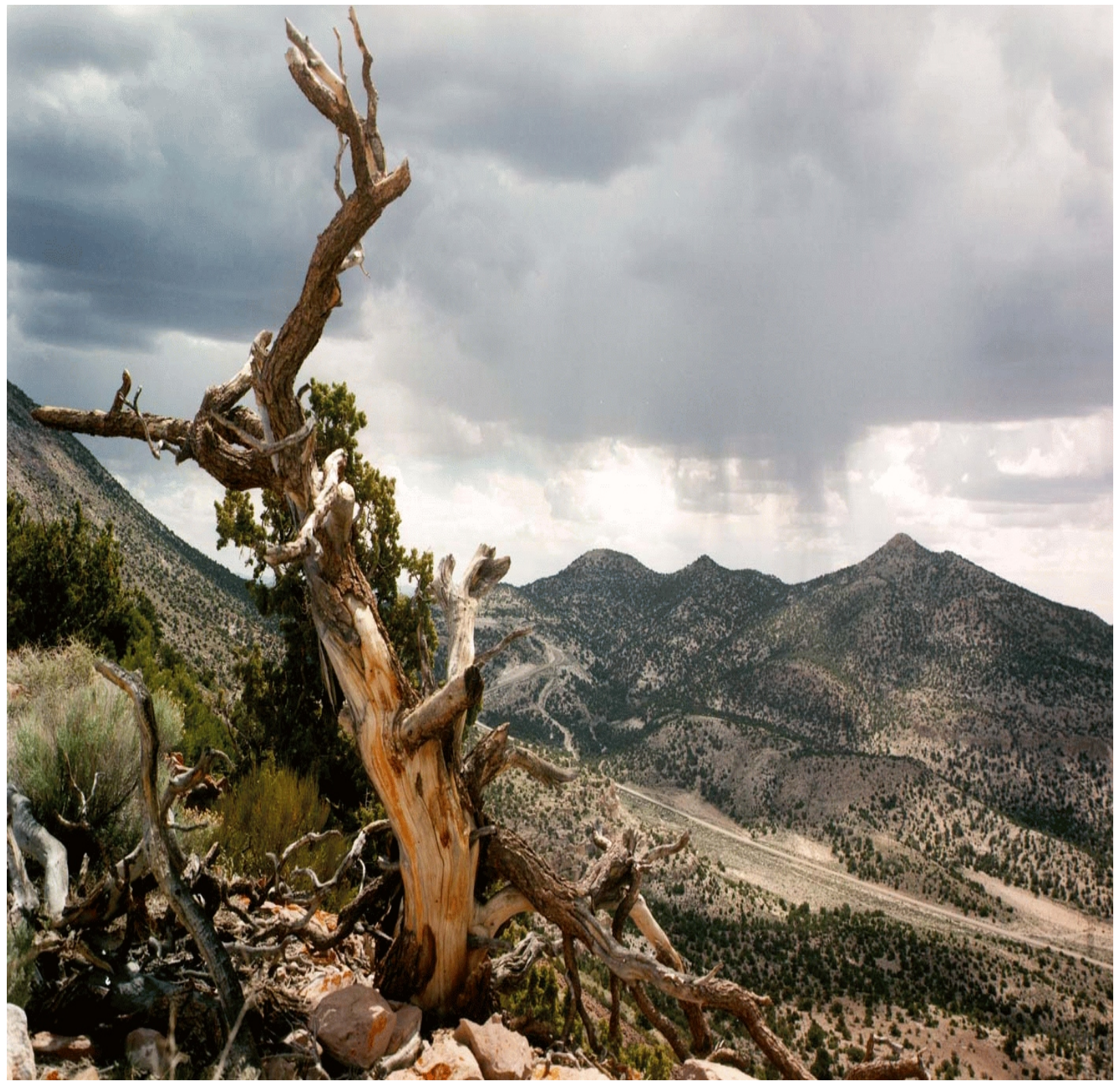

Bristlecone Pine, Rainier Mesa, and Stockade Wash, Nevada Test Site 
This page intentionally left blank. 


\subsection{Approval Process}

All waste/material offered for disposal/storage shall be evaluated pursuant to DOE Order 435.1, Change 1. The following describes the approval process and generator document requirements used by NNSA/NSO to verify that waste generators have a program in place to ensure that compliant waste is shipped to the NTS.

Official interactions between the generator and NNSA/NSO are initiated through the generator's DOE oversight office or designated points of contact.

Corrective Action Requests (CARs) are issued to generator sites when conditions adverse to quality are identified.

A flow diagram of the approval process is provided in Appendix A.

\subsection{Generator Document Requirements}

Generators should contact NNSA/NSO WMD and verify that the proposed waste type can be accepted at the NTS. The generator shall develop, implement, and maintain the documents listed below.

\subsubsection{Waste Profiles}

A Waste Profile (WP) shall be prepared and submitted to NNSA/NSO for each waste stream proposed for disposal. The WP summarizes the waste form and characterization data, and shall include a list of referenced procedures, citing the number and title. The WP instructions, numbering, and format that must be used are available from NNSA/NSO or on the NNSA/NSO website at http://www.nv.doe.gov/emprograms/environment/wastemanagement/rwap.aspx..$^{7.5}$

\subsubsection{Waste Certification Plan}

A Quality Assurance Plan (QAP) shall be documented in accordance with Section 5.0 and submitted to NNSA/NSO.

\subsubsection{NTSWAC Implementation Crosswalk}

An NTSWAC Implementation Crosswalk (NIC) shall be prepared and submitted to NNSA/NSO in accordance with Section 5.0. ${ }^{7.5}$ An electronic copy of the NIC is available from NNSA/NSO or on the NNSA/NSO website at http://www.nv.doe.gov/emprograms/environment/wastemanagement/rw ap.aspx 


\subsubsection{Certification Personnel List}

A current list identifying the Waste Certification Official(s) (WCOs), alternate WCOs, and Package Certifier(s) shall be developed and submitted to NNSA/NSO in writing. ${ }^{7.5}$ The list shall include the name and telephone number of each individual authorized to certify waste packages and shipments. ${ }^{75}$ This information is used by RWMC personnel to verify signatures on the Package Certification Labels (PCLs) and to assure that shipments are from authorized personnel. Any packages or shipments certified by unauthorized personnel shall not be accepted by the RWMC.

\subsubsection{Document and Personnel Changes}

Generators shall notify NNSA/NSO in writing of any changes to the above documents and/or key personnel. Prior to implementation, the WCO shall immediately notify NNSA/NSO in writing of any critical process and/or procedure changes to the approved certification program. ${ }^{7.5}$ Examples of critical processes and/or procedures include, but are not limited to, the following:

- Changes in inspection frequency;

- Changes in characterization methodology; and,

- Changes in training requirements.

Assistance in determining critical processes and/or procedures requiring written notification can be obtained from the RWAP Task Manager.

\subsection{RWAP Review}

NNSA/NSO's approval process for a generator's waste certification program and waste streams includes document reviews and on-site evaluations to verify program implementation. During these evaluations, CARs may be issued when conditions adverse to quality are identified by NNSA/NSO. CARs require the generator to document a root cause, corrective action, and action to preclude recurrence. Failure to respond to CARs could lead to delays in approval or result in suspension in accordance with Section 2.4.

\subsubsection{Facility Evaluations}

Facility evaluations (audits, surveillances) are scheduled and conducted by RWAP. 


\subsubsection{Biennial Audit}

New generators shall submit the documents described in Section 2.1 to NNSA/NSO prior to scheduling their initial audit. $^{7.5}$ Audits of approved generators are scheduled and conducted on a biennial basis.

The purpose of the biennial audit is to examine and evaluate objective evidence to verify that the documents contain the necessary elements and are adequately implemented. The audit scope will include an on-site evaluation of the characterization, QA, and waste traceability program elements. Audits are both performance- and program-based.

\subsubsection{Surveillance}

Scheduled or unscheduled surveillances may be performed to evaluate specific program elements, new waste streams, and verify implementation of corrective actions.

\subsubsection{Waste Profiles}

Waste profiles shall be submitted for review through the Waste Acceptance Review Panel (WARP) process. ${ }^{7.5}$ The WARP may require additional information from the generator, may recommend surveillance, or may recommend NNSA/NSO approval or suspension of the waste stream.

New generators shall complete and submit at least one profile to NNSA/NSO for review prior to the initial audit.

WPs for new waste streams or changes to approved waste streams may be submitted to NNSA/NSO for review by the WARP at any time.

The WCO shall perform a documented annual review of NTS-approved LLW WPs, based on the current revision date of each profile, to ensure the characterization data, waste stream information, and referenced procedures are current. ${ }^{7.5}$ For the recertification of Mixed Waste Profiles (MWP), see Section 3.3.3.

Changes to approved WPs shall be submitted to NNSA/NSO for review by the WARP. ${ }^{7.5}$ Depending on the significance of the changes, the approval to ship may be temporarily suspended until the changes are reviewed and accepted. 
Generators shall notify NNSA/NSO in writing when terminating an approved WP (project is complete, one-time-only waste stream has been shipped, etc.).

\subsubsection{Split Sampling}

The purpose of the split sampling program is to verify the results of waste analysis. NNSA/NSO may select a waste stream for split sampling based on its annual volume, the potential for finding hazardous components, or the scope and complexity of the sampling process to be performed. NNSA/NSO may require split sampling prior to the waste stream being approved.

Samples will be collected by the generator's sampling team under the observation of an RWAP representative. NNSA/NSO may split a representative waste sample with the generator for independent analysis. Samples will be sent to the generator laboratory and to an independent laboratory chosen by NNSA/NSO. The samples will be analyzed by the same analytical methods. Results of the analyses from both laboratories will be compared by RWAP after data validation. Differences between the two sets of data may require further investigation.

\subsection{Approval}

RWAP personnel recommend to NNSA/NSO AMEM that approval be granted after the generator has demonstrated satisfactory implementation of the NTSWAC. The NNSA/NSO AMEM will provide written notice of approval, identifying the last facility evaluation number, current Waste Certification Program Plan (WCPP) or QAP and revision, and approved waste stream(s). Conditions affecting waste stream approval will be identified.

Approved waste generators shall ensure that the following documents are maintained current within the NNSA/NSO RWAP while their approval to ship waste is in effect: ${ }^{7.5}$

- List of Authorized Certification Personnel

- Latest approved WP (Active WPs Only)

- Controlled copy of the QAP

- NIC

\subsection{Suspending Approval}

NNSA/NSO may suspend approval if generator's waste or documents do not meet the NTSWAC requirements. Individual waste streams or the generator's entire 
program may be suspended. Suspension may be issued verbally by NNSA/NSO representatives, followed by official written notification. Reasons for suspension may include, but are not limited to:

- Improper manifesting (e.g., incorrect nuclide inventory or activity level reported),

- Repetitive programmatic deficiencies,

- Incorrect waste characterization,

- Waste container integrity deficiencies,

- Inadequate nuclear criticality safety limits, and

- Facility evaluation results.

\subsection{Technical Support}

NNSA/NSO provides qualified technical assistance on NTSWAC issues at no cost to the generator. Generators wanting an independent review and one-on-one consulting on issues regarding their low-level waste management program are encouraged to contact NNSA/NSO. NNSA/NSO assistance to waste generators includes:

- Gap-Analysis site visits

- Policy and regulatory interpretations

- Waste packaging and transportation issue assistance

For additional information on requesting technical support, contact the NNSA/NSO RWAP Task Manager at (702) 295-2969.

\subsection{NNSA/NSO Policy}

Because of changes in regulatory requirements, NTS policies, and changes instituted as a result of lessons learned, any aspect of the waste certification process may be subject to a full review to ensure its compliance with any changed requirements and effectiveness. This review may entail imposing additional requirements or reversing previous decisions. Unannounced facility evaluations may be performed at the discretion of NNSA/NSO. 
This page intentionally left blank. 


\section{0}

\section{Waste Criteria}

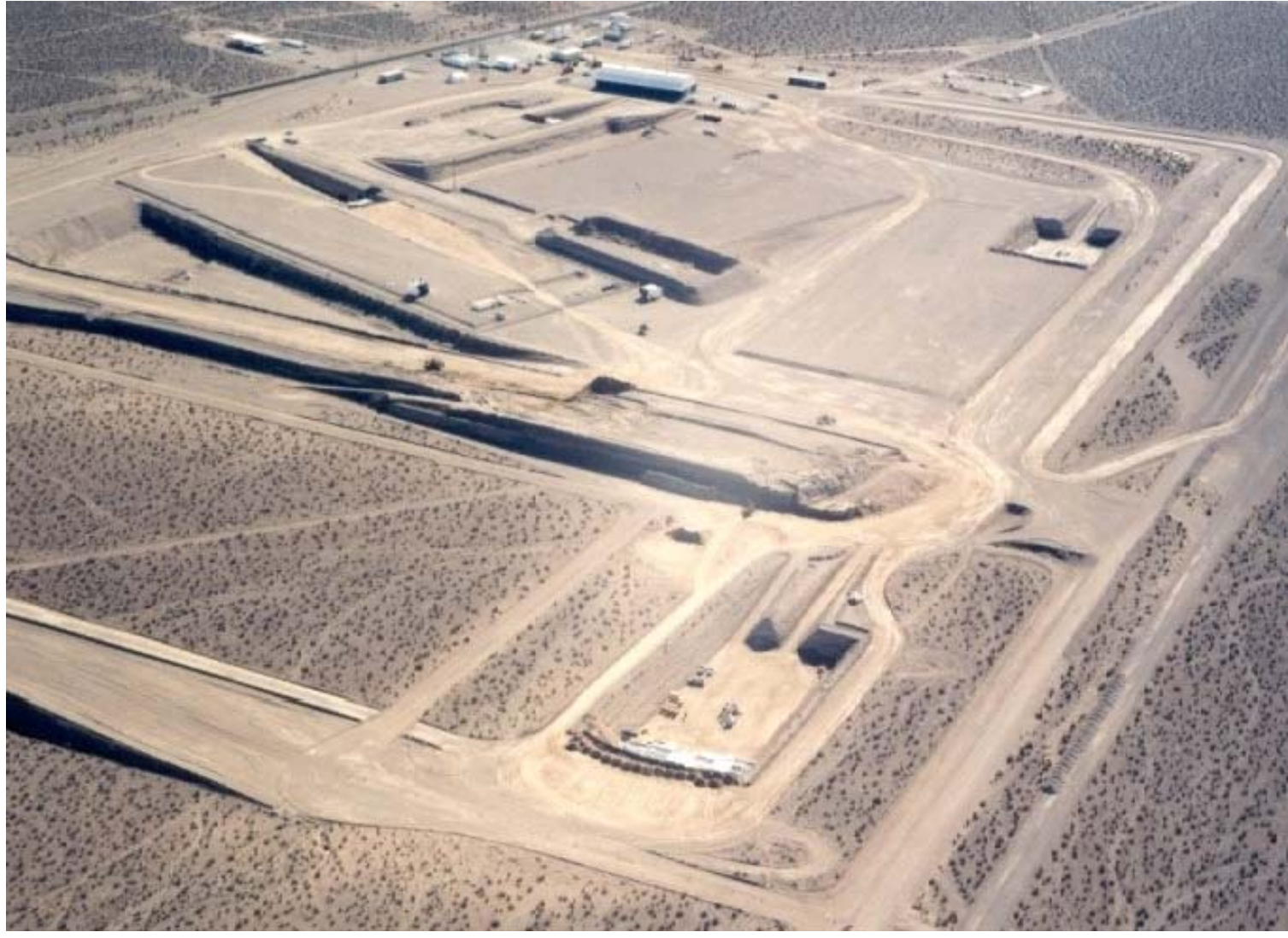

Area 5 Radioactive Waste Management Complex, Nevada Test Site 
This page intentionally left blank. 


\subsection{Waste Criteria}

Waste accepted at the NTS must be radioactive and shall meet the waste form criteria outlined below. ${ }^{6.6}$ Generators must ensure that waste is handled, stored, and shipped in accordance with applicable DOE, DOT, U.S. Environmental Protection Agency (EPA), state, and local regulations and requirements. Waste streams deviating from these requirements will be evaluated in accordance with Section 3.4, WAC Deviations.

\subsection{General Waste Form Criteria}

These waste form criteria are based on DOE radioactive waste management policies and practices.

\subsubsection{Transuranics}

The concentration of alpha-emitting transuranic nuclides with half-lives greater than 20 years must not exceed $100 \mathrm{nCi} / \mathrm{g}$. ${ }^{6.5}$ The net weight of the waste (excluding the weight of the container and shielding) must be used to calculate the specific activity of the waste in each container. The following isotopes shall be considered when making the transuranic waste determination: ${ }^{237} \mathrm{~Np},{ }^{238} \mathrm{Pu},{ }^{239} \mathrm{Pu},{ }^{240} \mathrm{Pu},{ }^{242} \mathrm{Pu},{ }^{244} \mathrm{Pu},{ }^{241} \mathrm{Am},{ }^{24 \mathrm{~m}} \mathrm{Am}$, ${ }^{243} \mathrm{Am},{ }^{243} \mathrm{Cm},{ }^{245} \mathrm{Cm},{ }^{246} \mathrm{Cm},{ }^{247} \mathrm{Cm},{ }^{248} \mathrm{Cm},{ }^{250} \mathrm{Cm},{ }^{247} \mathrm{Bk},{ }^{249} \mathrm{Cf},{ }^{251} \mathrm{Cf}$. Additional information on determining the transuranic alpha concentration can be found in the document "Determining Transuranic Alpha Activity Concentration for Compliance with NTSWAC" located at the web address http://www.nv.doe.gov/emprograms/environment/wastemanagement/rw ap.aspx.

\subsubsection{Radionuclide Content or Concentration}

Radionuclide concentration must be reported in accordance with Appendix E, "Radionuclide Characterization and Reporting Requirements." ${ }^{6.76 .166 .18}$ Radionuclide limits for disposal are listed in Table E- 1, "Radionuclide Action Levels for Waste Characterization and Reporting." Waste having radionuclide concentrations above these limits may be acceptable for disposal upon review by NNSA/NSO, provided the content does not exceed the package activity limits identified in Section 3.2.2.

\subsubsection{Commercial Greater-Than-Class-C Waste}

Greater-Than-Class-C waste, as defined by Title 10 CFR 61.55, generated by U.S. Nuclear Regulatory Commission (NRC) licensees shall not be accepted for disposal at the NTS. 


\subsubsection{Hazardous Waste}

Waste regulated solely under Title 40 CFR 261-268 and state of Nevada hazardous waste regulations shall not be accepted for disposal. ${ }^{3.354}$ State of Nevada regulations require that waste regulated as hazardous in the state of generation must be regulated as hazardous when brought into the state of Nevada; therefore, such waste shall not be accepted for disposal. $^{5.3}$ For MW, see Section 3.3.

Environmental media from cleanup activities may be acceptable for disposal if:

The state of origin makes a "Contained-In Determination" for LLW environmental media that was in contact with "listed" wastes. The generator must submit this determination to NNSA/NSO for evaluation, and provide and demonstrate:

- Documentation that the waste is primarily environmental media (not debris). For the purpose of this determination, environmental media is defined as materials found in the natural environment such as soil, groundwater, surface water, and sediments; or a mixture of such with liquids, sludges, or solids which is inseparable by simple mechanical removal processes;

- Documentation that the media was representatively sampled and evaluated for total contaminant concentrations $(\mathrm{mg} / \mathrm{kg}$ ) and Toxicity Characteristic Leaching Procedure (TCLP) concentrations (mg/L) where applicable;

- If the treatment standard is provided in " $\mathrm{mg} / \mathrm{kg}$ " (totals), the "listed" constituents must be less than one-tenth of the concentration of the RCRA Land Disposal Restriction (LDR) (Title 40 CFR 268.40). If the treatment standard is provided in "mg/l TCLP," the TCLP concentration must be less than the Safe Drinking Water Act Standard (MCL);

- Laboratory data including QA/Quality Control data;

The Nevada Department of Conservation and Natural Resources, Division of Environmental Protection (NDEP) will evaluate the state of origin "Contained-In Determination" on a case-by-case basis for concurrence and will issue written correspondence through the WARP process once the generator has provided and demonstrated the abovestated items.

Debris contaminated with "listed" constituents will be evaluated, independent of the criteria established above for environmental media. 


\subsubsection{Free Liquids}

Liquid waste and waste containing free liquids must be converted into a form that contains as little free-standing and noncorrosive liquid as is reasonably achievable..$^{6.11}$ Liquid waste and waste containing free liquids should be processed to a solid form or packaged in sufficient sorbent for twice the volume of the liquid. The free liquid must not exceed 1 percent of the volume of the waste when the waste is in a disposal container; or 0.5 percent of the volume of the waste processed to a solidified form. ${ }^{6.11}$ Provisions for additional sorbent should be made when significant temperature and atmospheric differences exist between the generating site and the disposal site.

Waste must be evaluated to determine its potential to release liquid during handling, storage, and transportation. ${ }^{7.6}$ High moisture content waste is defined as waste that has the potential to release moisture from its final waste form in excess of the NTSWAC requirement. Generators must document the decisions made when characterizing and determining sorbents for high moisture content waste (see the Nevada Test Site Generator Work Group "Position Paper for High Moisture Content Waste," Revision 0, dated 11/3/1998, for use as guidance located at http://www.nv.doe.gov/emprograms/environment/wastemanagement/rw ap.aspx).

\subsubsection{Particulates}

Fine particulate wastes shall be immobilized so that the waste package contains no more than 1 weight percent of less-than-10-micrometerdiameter particles, or 15 weight percent of less-than-200-micrometerdiameter particles. $^{7.6}$ Waste that is known to be in a fine particulate form or in a form that could mechanically or chemically be transformed to a particulate during handling and interim storage must be immobilized."

Secure packaging may be used in place of immobilization. The following are examples of acceptable packaging: overpacking (i.e., 55-gallon drum inside 85 -gallon drum); steel boxes; drums with a sealed, 6 mil minimum (or equivalent) liner; and wooden boxes with a sealed, 6 mil minimum (or equivalent) liner. Disposal containers with contents individually wrapped and sealed in plastic are also acceptable.

\subsubsection{Gases}

LLW gases must be packaged at a pressure that does not exceed 1.5 atmospheres absolute at $20^{\circ} \mathrm{C} . .^{6.4776}$ Compressed gases as defined by Title 49 CFR shall not be accepted. ${ }^{7.6}$ Examples of compliance methods include puncturing aerosol cans and removing the valve mechanism from expended gas cylinders. 


\subsubsection{Stabilization}

Where practical, waste must be treated to reduce volume and provide a more stable waste form. ${ }^{6.23}$ Wastes must not react with other wastes or the packaging during storage, shipping, handling, and disposal.

Structural stability can be accomplished by crushing, shredding, or placing a smaller piece inside an opening of a larger piece, such as nesting pipes

Chemical stability and compatibility must be demonstrated to ensure that no reactions occur and significant quantities of harmful gases, vapors, or liquids are not generated ${ }^{6.13}$ (specifically when different waste forms are combined in a single waste container).

\subsubsection{Etiologic Agents}

LLW containing pathogens, infectious wastes, or other etiologic agents as defined in Title 49 CFR shall not be accepted.

\subsubsection{Chelating Agents}

LLW packages containing chelating or complexing agents in amounts greater than 1 percent of the waste shall not be accepted unless stabilized or solidified.

\subsubsection{Polychlorinated Biphenyls (PCBs)}

LLW containing PCBs that meet the standards under Title 40 CFR 761.50(b)(7) for disposal in DOE Order 435.1 landfills will be accepted. PCB-contaminated LLW must be packaged, marked, and labeled in accordance with the requirements of Title 40 and Title 49 CFR. Packages containing PCB-contaminated LLW must meet the applicable shipping requirements for the radioactive content of the package.

Generators must provide written notice a minimum of 15 days in advance of the first shipment of each waste stream containing PCB bulk product waste. $^{3.21}$ The notice shall be faxed to Bechtel Nevada (BN) at (702) 295-6852 and shall state the following: (1) This waste may include components containing PCBs at greater than or equal to $50 \mathrm{ppm}$ (based on analysis or process knowledge), and (2) This waste is known or presumed to leach less than 10 micrograms of PCBs per liter of water. $^{3.21}$ [Note: Waste presumed to leach less than 10 micrograms of PCB per liter of water are those in which PCBs are tightly bound within 
a matrix. EPA lists the following as included in such waste: Plastics; preformed or molded rubber; applied dried paints, varnishes, waxes, or other coating or sealants; caulking; nonliquid building demolition debris; and shredder fluff.]

\subsubsection{Explosives}

Waste must not be readily capable of detonation or of explosive decomposition or reaction at normal pressures and temperatures, or of explosive reaction with water.

\subsubsection{Pyrophorics}

Waste must not be pyrophoric. ${ }^{6.12}$ Pyrophoric materials contained in the waste shall be treated, prepared, and packaged to be nonflammable. Pyrophoric materials that are blended in a hardened concrete matrix are considered to be treated to be nonflammable.

\subsubsection{Sealed Sources}

Sources containing transuranic nuclides must be individually evaluated against the transuranic criteria (Section 3.1.1), considering only the mass of the source and any component integral to the source.

Sealed sources that have an activity of less than $3.7 \mathrm{MBq}(100 \mu \mathrm{Ci})$ can be a component of waste streams such as contaminated trash. The total volume of the waste can be used for waste classification and for determination of the radionuclide concentration. Characterization of non-transuranic sources (i.e., less than $3.7 \mathrm{MBq}[100 \mu \mathrm{Ci}]$ ) on an individual source basis is not required, provided that the characterization method used is adequate to ensure compliance with the radionuclide reporting criteria.

Sealed sources that have an activity of $3.7 \mathrm{MBq}(100 \mu \mathrm{Ci})$ or greater shall be segregated from other waste and profiled as a separate waste stream. ${ }^{7.3}$ These sealed sources shall be characterized on an individual basis using the volume or mass of the source to determine the radionuclide concentration ${ }^{7.3}$ Sealed sources may be co-packaged with other waste streams provided Section 3.0, Waste Criteria," are met.

Additional guidance on the definition, proper packaging, and characterization of sealed sources can be found in the "Position Paper on the Proper Characterization and Disposal of Sealed Radioactive Sources," located at the web address below: http://www.nv.doe.gov/emprograms/environment/wastemanagement/rw ap.aspx 


\subsubsection{Low-Level Waste Containing Asbestos}

Asbestiform Low-Level Waste (ALLW) is defined as any LLW containing friable asbestos material; Category I nonfriable asbestoscontaining material (ACM) that has become friable; Category I nonfriable ACM that will be or has been subjected to sanding, grinding, cutting, or abrading; or Category II nonfriable ACM that has a high probability of becoming or has become crumbled, pulverized, or reduced to powder. ALLW must be packaged, marked, and labeled in accordance with the requirements of Title 40 CFR, State of Nevada Solid Waste Disposal Site Permit (SW1300001, current revision), state-ofgeneration, and the NTS Management Plan for the Disposal of LowLevel Waste with Regulated Asbestos Waste, current revision.

Packages containing ALLW must meet the applicable shipping requirements for the radioactive contents of the package. ${ }^{4.5}$ ALLW must be wetted with a water and surfactant mixture and packaged in a plastic bag which is not less than 6 mil in thickness, a combination of plastic bags which equal at least 6 mil in thickness, or a container which is lined with plastic."

If free liquid is present, sorbent must be added to ensure compliance with the free-liquids criteria. ${ }^{6.11}$ Sharp edges and corners in the package must be padded or protected to prevent damage to the plastic bag during handling, shipping, and disposal."

Each container used to dispose ALLW must bear a label that contains one of the statements below.

\begin{tabular}{|c|} 
(1) CAUTION \\
CONTAINS ASBESTOS FIBERS \\
AVOID OPENING OR BREAKING CONTAINER \\
BREATHING ASBESTOS IS HAZARDOUS TO YOUR HEALTH \\
\hline $\begin{array}{c}\text { (2) CAUTION CONTAINS ASBESTOS FIBERS } \\
\text { AVOID CREATING DUST }\end{array}$ \\
MAY CAUSE SERIOUS BODILY HARM \\
\hline
\end{tabular}

ALLW must be segregated into a separate waste stream. ${ }^{79}$ Because of state notification requirements and disposal cell capacity, ALLW must be packaged separately from other waste streams. ${ }^{7.2}$ Call NNSA/NSO WMD at (702) 295-7063 for assistance and a copy of the current NTS Management Plan for the Disposal of Low-Level Waste with Regulated Asbestos Waste, which includes specific requirements for pre-shipment notifications. The pre-shipment notification must be faxed to 
NNSA/NSO at least seven (7) days prior to shipment arrival. ${ }^{7.5}$ A signed copy of the notification will be returned to the generator indicating authorization of the shipment.

\title{
3.1.16 Radioactive Animal Carcasses
}

Animal carcasses containing, or contained in, radioactive materials shall be packaged with the biological material layered with lime and placed in a metal container meeting applicable requirements. ${ }^{1.1 / 2.27 .6}$ If the resultant waste matrix is capable of gas generation, the container shall be vented with a carbon composite High-Efficiency Particulate Air (HEPA) filtration device. ${ }^{1.1 / 6.6} \mathrm{NNSA} / \mathrm{NSO}$ may require analysis of the waste decomposition gases. Animal carcasses preserved with formaldehyde shall not be accepted for disposal.

\subsubsection{Low-Level Beryllium Waste}

For this section, beryllium is defined as elemental beryllium and any insoluble beryllium compound or alloy containing 0.1 percent beryllium or greater that may be released as an airborne particulate. Berylliumcontaining waste, and beryllium-contaminated equipment must be packaged in sealed, impermeable bags (minimum 6 mil), containers, or enclosures to prevent the release of beryllium dust during handling and transportation. ${ }^{1.37 .6}$ The bags, containers, and enclosures must be labeled with the following information ${ }^{1.4}$ :

\author{
"DANGER, CONTAMINATED WITH BERYLLIUM \\ DO NOT REMOVE DUST BY BLOWING OR SHAKING \\ CANCER AND LUNG DISEASE HAZARD”
}

\subsubsection{8 “Classified Waste”}

"Classified Waste" must be segregated into a separate waste stream. For "Classified Waste" requiring protection from visual observation, the Advance Shipment Notification identified in Appendix C.4 must be faxed to $\mathrm{BN}$ at (702) 295-6852 at least seven (7) days prior to shipment arrival. $^{7}$

\subsection{Waste Package Criteria}

Waste packages must meet applicable DOE Orders, Title 10 CFR, Title 40 CFR, and Title 49 CFR requirements such as: design, nuclear safety, radiation levels, activity limits, nuclear heating, and multiple hazards. Waste packages must be capable of withstanding the stresses associated with the loading, handling, stacking, and shipping of the package. 
NNSA/NSO has adopted the following waste package criteria to assure that the NTS RWMC is operated safely and efficiently:

\subsubsection{Nuclear Criticality Safety}

The quantity of fissile (fissionable) material in a waste package shall be limited so that an infinite array of such packages will be subcritical under "as packaged" conditions and if the array were to be flooded with water to any credible degree. ${ }^{627.15}$ Waste packages shall comply with the fissile material limits in Appendix E. ${ }^{7.5}$ Compliance of a waste package with the fissile material limits is required to be documented in the WP.

\subsubsection{Package Activity Limitations}

Package Activity limits at the NTS are based on Plutonium-239 equivalent grams (PE-g). Packages offered for disposal must have PE-g limits in accordance with the table below. ${ }^{7.6}$ These limits correspond to the type of package being disposed, not the shipping container (i.e., a plastic bag inside a reusable container, once dumped must meet the softsided package limits). PE-g calculations are confirmed by NTS personnel prior to shipment receipt based on the Package Storage and Disposal Request (PSDR). Any package in excess of these limits will result in the entire shipment being refused by NTS personnel. Conversion factors for PE-g from Becquerels can be found in Appendix B. For assistance in developing conversion factors for isotopes not listed in Appendix B, contact NNSA/NSO.

Table 3.1 Package Activity Limits

\begin{tabular}{|l|l|}
\hline Package type & PE-g limits \\
\hline LLW DOT Type-A Drum & 300 PE-g total \\
\hline LLW Standard Waste Box & 300 PE-g total \\
\hline Soft-Sided Packages (supersacks, etc.) & 300 PE-g total \\
\hline $\begin{array}{l}\text { Strong-Tight Container (Sealands, } \\
\text { etc.) }\end{array}$ & 300 PE-g total \\
\hline HSA Container (DOT Type A) & 300 PE-g total \\
\hline DOT Type B containers (Supertigers) & No limit if type B container is disposed \\
\hline
\end{tabular}

PE-g limits for NTS shipments are limited to 2,000 PE-g per shipment. For example, two cargo containers with 300 PE-g each may be shipped together, but 10 drums of $250 \mathrm{PE}-\mathrm{g}$ each may not be shipped together because the total is greater than 2,000 PE-g. This does not apply to shipments made exclusively of DOT Type B containers where the Type B containers are for disposal. 
NTSWAC deviations are available for all hard sided packages that may increase the PE-g limit per package and/or per shipment if permitted by the waste facility safety basis.

\subsubsection{Closure}

The package closure must be sturdy enough that it will not be breached under normal handling conditions.

\subsubsection{Lead Shielding}

The use of lead for shielding (radioactively contaminated or radioactively uncontaminated) in containers for the disposal of LLW is an acceptable practice. Generators must maintain the following:

- $\quad$ Documentation demonstrating that standard packaging without lead shielding would not reduce the exposure rate to less than $0.005 \mathrm{rem} / \mathrm{hr}(5 \mathrm{mrem} / \mathrm{hr})$ at 30 centimeters and the shielding is necessary for radiation protection; and,

- Documentation demonstrating that the amount of lead used for shielding is not excessive for each specific container of LLW. The documentation shall include calculations demonstrating the amount of lead (thickness/quantity) in the container is not excessive by justifying the quantity of lead required in each given container, or on a container-by-container basis. Justification for using the appropriate amount of lead shielding can be demonstrated by a detailed dose rate survey that shows the shielded dose rate exceeds $0.005 \mathrm{rem} / \mathrm{hr}$ at $30 \mathrm{~cm}$ from the waste package.

Additional information on the use of lead shielding can be found in the "Position Paper On The Use Of Lead Shielding For The Disposal Of Low Level Waste At The Nevada Test Site," located at the web address below:

http://www.nv.doe.gov/emprograms/environment/wastemanagement/rw ap.aspx

\subsubsection{Strength}

The disposal package (packaging and contents) must be capable of supporting a uniformly distributed load (compressive strength) of $16,477 \mathrm{~kg} / \mathrm{m}^{2}\left(3,375 \mathrm{lbs} / \mathrm{ft}^{2}\right)$. 
This is required to support other waste packages and earth cover without crushing during stacking and covering operations. Actual physical testing or design engineering calculations may be used to demonstrate this requirement. This requirement does not apply to bulk waste, waste packaged in steel drums, or cargo containers.

Bulk waste containers, including cargo containers, must be sufficiently strong to not breach under normal offloading conditions. ${ }^{7.6}$ Bulk waste containers with a reasonable probability of breaching during offloading (i.e., burrito wraps), regardless of the type of transport vehicle (i.e., intermodals), must meet the package activity limitations of Section 3.2.2. ${ }^{1.6}$ All alternative packaging will be evaluated by NTS operations on a case-by-case basis. Alternative packaging approval will be dependent on waste stream characteristics.

\subsubsection{Handling}

Handling procedures and ALARA documentation must be referenced on the WP for wastes requiring remote handling. ${ }^{7.6}$ The disposal site may request this documentation. Packages exceeding $1 \mathrm{mSv} / \mathrm{hr}(100 \mathrm{mR} / \mathrm{hr})$ dose rate at 30 centimeters shall be considered for remote handling." Remote handling will incur additional cost for the generator and may delay the profile approval process. Waste streams with packages exceeding $100 \mathrm{mR} / \mathrm{hr}$ at 30 centimeters or alternative packages (i.e., supersacks, plastic wraps) require RadCon approval and may be evaluated against the Documented Safety Analysis using the Unreviewed Safety Question process.

Waste packages must be provided with cleats, offsets, rings, handles, permanently attached or removable skids, or other auxiliary lifting devices to allow handling by means of forklifts, cranes, or similar handling equipment. ${ }^{7.6}$ All waste streams with packages requiring cranes for off-loading must have an approved lift plan generated by NTS Operations prior to shipment. ${ }^{7.6}$ Additional costs incurred by this development and implementation will be the responsibility of the waste generator. Removable skids are preferred to assist in meeting NTS Performance Assessment objectives for reducing disposal cell subsidence. Lifting rings and other auxiliary lifting devices on the package are permissible, provided that they are recessed, offset, or hinged in a manner that does not inhibit stacking the packages. Auxiliary lifting devices for any portion of the package extending from the top of the waste package must be no higher than 0.1 meter (4 inches) in normal position. ${ }^{7.6}$ The lifting devices must be designed with a 5:1 safety factor based on the ultimate strength of the material. All rigging devices that are not permanently attached to the waste package must have a current load test based on 125 percent of the safe 
working load. $^{7.19}$ Permanently attached rigging devices shall have traceable certifications. ${ }^{7.6}$ They must not show any signs of corrosion, kinking, birdcaging, or other deterioration."

LLW packages that have abnormal centers of gravity must be clearly marked with the center of gravity. ${ }^{7.6}$ Top-heavy loads are severely discouraged, and bulk waste shipments with complex geometries shall be loaded in the most stable configuration. ${ }^{7.6}$ Cargo containers are exempted from this requirement until the gross weight exceeds 30,000 lbs.

\subsubsection{Size}

Boxes measuring 1.2- x 1.2- x 2.1-m (4- x 4- x 7-ft) or 1.2- x 0.6- x 2.1-m (4- x 2- x 7-ft) (width $x$ height $x$ length, plus or minus $1 / 2$ inch) or 208-liter (55-gallon) drums should be used. These sizes allow optimum stacking efficiency in disposal cells. Alternate packages (i.e., supersacks, burrito wraps) will be considered; however, RWMC operations personnel need to be consulted to ensure equipment compatibility. MW, "Classified Waste," ALLW, PCBs, or Low-Level HydrocarbonBurdened waste that is not packaged in hard-sided containers meeting the strength requirement, allowing the packages to be stacked at least 14 feet high in a safe and stable manner, may incur additional handling costs.

Bulk waste generally exists in a form not suited to the conventional packaging requirements. Bulk LLW must meet the requirements of Title 49 CFR. ${ }^{4.7}$ Large items of bulk waste, such as machinery, may be considered for disposal unpackaged. For the transfer of unpackaged bulk material having external contamination, the contamination must be fixed, covered, or contained sufficiently for safe transfer. ${ }^{4.8}$

Refer to Appendix F for specific packaging requirements and limitations for intermodal (Roll-off boxes) containers that will be returned to the generator. All other types of containers that are requested to be returned will be evaluated on a case-by-case basis during the waste profile review process. The request that containers be returned should be identified in the special-handling section of the waste profile. The return of bulk containers may incur additional operational costs.

\subsubsection{Weight}

In addition to the weight limits for specific packaging designs, packages shall not exceed 4,082 $\mathrm{kg}(9,000 \mathrm{lbs})$ per box and $544 \mathrm{~kg}(1,200 \mathrm{lbs})$ per drum. $\quad$ This weight limit does not apply to bulk waste. 


\subsubsection{Loading (Void Space)}

Waste packages must be loaded to ensure that the interior volume is as efficiently and compactly loaded as practical to minimize void space. More than one waste stream may be packaged in a disposal container, except those waste streams that must be profiled separately (MW, "Classified Waste," ALLW, etc.). ${ }^{757.68 .0}$ MW packages must meet the void space criteria in Section 3.3.6.2.

\subsubsection{Package Protection}

Methods must be employed to ensure that the integrity of the in-process waste package is not compromised (i.e., prohibited items are not introduced into the waste package).

Once the waste package certification activities have been completed and the packages have been sealed, the packages must be stored in a secure, protected area to prevent deterioration and unauthorized intrusion. Storage should include protection from adverse weather, particularly

rain and snow. Tamper-indicating devices (TIDs), clips, or banding can be used to indicate that the package has not been opened. These devices shall not contain lead."

\subsubsection{Marking and Labeling}

Each waste package must be marked and labeled according to Appendix $C .^{7.6}$ Markings and labels must be intact and readable when the shipment arrives at the disposal site.

\subsubsection{Bar Coding}

The shipment and package numbers must be bar coded according to the standards in Appendix C.

\subsubsection{Contamination Levels}

External contamination levels for waste packages and transport vehicles must meet the release limits specified in Title 10 CFR Part 835, Appendix D.

\subsection{Mixed Waste}

MW offered for disposal must meet the applicable characterization, treatment, 
packaging, and disposal requirements of the NTSWAC, Title $40 \mathrm{CFR}$, state of Nevada, and state-of-generation regulations.

\subsubsection{Acceptable Hazardous Waste Numbers}

MW accepted for disposal must have one or more of the EPA hazardous waste numbers listed below or must be considered a hazardous waste in the state of generation:

Waste Codes: D004 through D043

F001 though F009, F039

P001 through P205

U001 through U249, U271, U278, U279, U280, U328, U353, U359, U364, U367, U373, U387, U389, U394, U395, U404

\subsubsection{Mixed Waste Treatment Notification}

Generators with MW that requires treatment to meet the LDR standards, but the treatment has yet to occur, must submit to NNSA/NSO the information contained in the Pre-Treatment Notification Form found in Appendix G. ${ }^{8.0}$ This will allow the scheduling of on-site verification activities in accordance with Section 3.3.8.

If treatment is performed by a commercial facility, it shall have a current DOE Consolidated Audit Program (DOECAP) audit, or equivalent.

\subsubsection{Mixed Waste Profiles}

In addition to the NTSWAC requirements for waste profiles in Section 2.1.1, MWPs must be profiled and packaged separately from LLW. MWPs shall be approved for a finite volume of waste. ${ }^{8.0}$ MWPs shall include the number of containers, container sizes, and dose rates at $30 \mathrm{~cm}$ for the mixed waste covered by the MWP.

MWPs have annual expiration dates and must be recertified annually (based upon the profile revision date) to the NNSA/NSO with the information contained in Appendix G-2.

\subsubsection{Land Disposal Restrictions}

MW must meet the LDR treatment standard requirements in Nevada Administrative Code (NAC) 444.8632 (incorporating Title 40 CFR 268.40 and 268.45), including standards for underlying hazardous 
constituents (UHCs). Waste meeting the alternative LDR treatment standard for contaminated soil, as defined by NAC 444.8632

(incorporating Title 40 CFR 268.49), is also accepted.

LDR notifications/certifications shall be made in accordance with Section 6.3.4.

\subsubsection{Determinations of Equivalent Technology}

MWs that have been treated based on a Determination of Equivalent Technology (DET) will require NDEP concurrence on the DET. NDEP will require the DET documentation, including EPA regions' determinations. Any documentation of state-of-generation involvement in the DET should also be submitted.

\subsubsection{Waste Form Criteria/Prohibited Items}

MW accepted for disposal must meet the general waste form criteria as described in Section 3.1 except as indicated below.

\subsubsection{Free Liquids}

Free liquids must be absorbed, stabilized, or otherwise removed from the waste. Containerized free liquids such as ampules, small articles that contain free liquids required for the article to function (e.g., batteries or capacitors), are acceptable.

\subsubsection{Sorbents}

Sorbents must be nonbiodegradable and identified on the MWP. ${ }^{3.9}$ Examples of nonbiodegradable sorbents according to Title 40 CFR 265.314(f) include:

- Inorganic minerals, other inorganic materials, and elemental carbon (e.g., aluminosilicates, clays, smectites, Fuller's earth, bentonite, calcium bentonite, montmorillonite, calcined montmorillonite, kaolinite, micas (illite), vermiculites, zeolites; calcium carbonate (organic free limestone); oxides/hydroxides, alumina, lime, silica (sand), diatomaceous earth; perlite (volcanic glass); expanded volcanic rock; volcanic ash; cement kiln dust; fly ash; rice hull ash; activated charcoal/activated carbon. 
- High molecular weight synthetic polymers (e.g., polyethylene, polypropylene, polyurethane). This does not include polymers derived from biological material or polymers specifically designed to be degradable.

- Sorbents determined to be nonbiodegradable under: American Society for Testing and Materials (ASTM) Method G21-70, Standard Practice for Determining Resistance of Synthetic Polymer Materials to Fungi; ASTM Method G22-76, Standard Practice for Determining Resistance of Plastics to Bacteria; or OWCS test 301B, $\mathrm{CO}_{2}$ Evolution.

\subsubsection{Compatibility}

Incompatible wastes, or incompatible wastes and materials shall not be placed in the same container if such placement:

- Generates extreme heat or pressure, fire or explosion, or violent reaction;

- Produces uncontrolled toxic mists, fumes, dusts, or gases in sufficient quantities to threaten human health;

- Produces uncontrolled flammable fumes or gases in sufficient quantities to pose a risk of fire or explosions;

- Damages the structural integrity of the device or facility containing the waste; or

- Through other like means threaten human health or the environment.

\subsubsection{MW Package Criteria}

In addition to Section 3.2, MW packaged for disposal must meet the waste package criteria below:

\subsubsection{Marking and Labeling}

In addition to the marking and labeling requirements in Appendix C, MW packages of 416 liters (110 gallons) or less must be marked with the following: 
- The words, "HAZARDOUS WASTE - Federal Law Prohibits Improper Disposal. If found, contact the nearest police or public safety authority of the U.S. Environmental Protection Agency";

- Generator's Name and Address;

- Manifest Document Number.

The marking must be durable, in English, displayed on a background of sharply contrasting color, printed or affixed to the surface of the package; or on a label, tag, or sign unobscured by other labels or attachments, located away from any marking that could substantially reduce its effectiveness.

Marking and labeling of the waste packages must be for the hazardous and radioactive characteristics of the waste.

\subsubsection{Void Space}

Containers of MW must be at least 90 percent full when placed in the landfill.

\subsubsection{Package Protection}

In addition to the requirements of Section 3.2.10, if a package has been inspected as part of the NTS verification plan, the TID must not be removed or altered. The package must be loaded and transported to protect the TID from damage.

\subsubsection{Analytical Data}

Analytical data used to make MW determinations or LDR certifications must be from a DOECAP audited laboratory, or equivalent.

\subsubsection{MW Verification}

Verification frequencies and methods for MWPs are determined by the WARP in accordance with RWAP procedures. The methods include: split sampling, field chemical screening, visual inspection and/or RealTime Radiography (RTR) at the generator or treatment facility and RTR at the NTS. Verification will be conducted in accordance with RWAP procedures. 


\subsubsection{MW Verification Frequency}

MW verification frequencies will be assigned by the WARP. A minimum of 5 percent of waste containers per MWP must be physically screened by either visual inspection or RTR.

Exceptions to the physical screening requirements must be approved by the NNSA/NSO RWAP Manager.

Unless exempted, a minimum of 10 percent of containers physically screened must be chemically screened. ${ }^{8.0}$ The following wastes are exempted from chemical screening:

- Waste subjected to an LDR-specified technology standard

- Hazardous debris

- Chemical-containing equipment removed from service (i.e., ballasts, batteries, etc.)

- MW containing regulated asbestos

- Waste from the cleanup of spills or a release of a single substance or known material (e.g., material for which a Material Safety Data Sheet [MSDS] can be provided)

- Confirmed noninfectious waste generated from laboratory tissue preparation, slide staining, or fixing processes.

- Waste containing beryllium.

Chemical screening of waste container contents will be performed by RWAP personnel at the generator's site. If a container is too large to RTR at NTS, the waste will be visually verified at the generator's site.

Generators shall provide the necessary authorizations, facilities, and personnel to allow for RWAP personnel to perform MW verification at the generator or treatment facility.

RWAP personnel must be provided access to containers and facilities to allow for visual inspection of the contents of packaged containers, performing chemical screening on homogeneous samples of the waste, and split sampling.

\subsubsection{Previously Rejected MW Packages}

Rejected MW packages (parent packages) that are repackaged and/or split into additional MW packages (progeny packages), must be traceable to the original package number. ${ }^{8.0}$ In addition to the transportation and shipping requirements of Section 6.0, 
generators shall notify NNSA/NSO prior to shipping previously rejected MW packages (parent and/or progeny) back to NTS.

\subsection{WAC Deviations}

Deviations from the NTSWAC that do not compromise the performance objectives for the disposal site, NTS Documented Safety Analysis requirements and limitations, or violate permit requirements may be accepted. The following information must be included with the WP: the NTSWAC requirement that cannot be met; the justification for not meeting the requirement; the duration of the deviation, if applicable; and the action plan to correct the deviation, if applicable.

\section{Example:}

Requirement: NTSWAC, Revision 6, Section 3.2.5, Strength, requires that the disposal package must be capable of supporting a uniformly distributed load of $16,477 \mathrm{~kg} / \mathrm{m}^{2}\left(3,375 \mathrm{lbs} / \mathrm{ft}^{2}\right)$.

Justification: Two 4- x 4- x 7-ft metal boxes (\#33248 and \# 33798) do not meet the NTSWAC strength requirement. The boxes contain contaminated soil from a remediation project. Because of ALARA concerns, the generator seeks to avoid unnecessary exposure to personnel during repackaging by allowing the waste to remain in the boxes. The boxes will be identified by marking "Box Does Not Meet Strength Requirement" on the tops of each container. Shipping and handling procedures provide details about these containers. The WCO certification checklist will ensure that the markings are applied and documented.

Duration: The duration of the deviation is one time only (boxes 33248 and 33798).

Corrective Action: None required. 


\section{0}

\section{Waste Characterization}

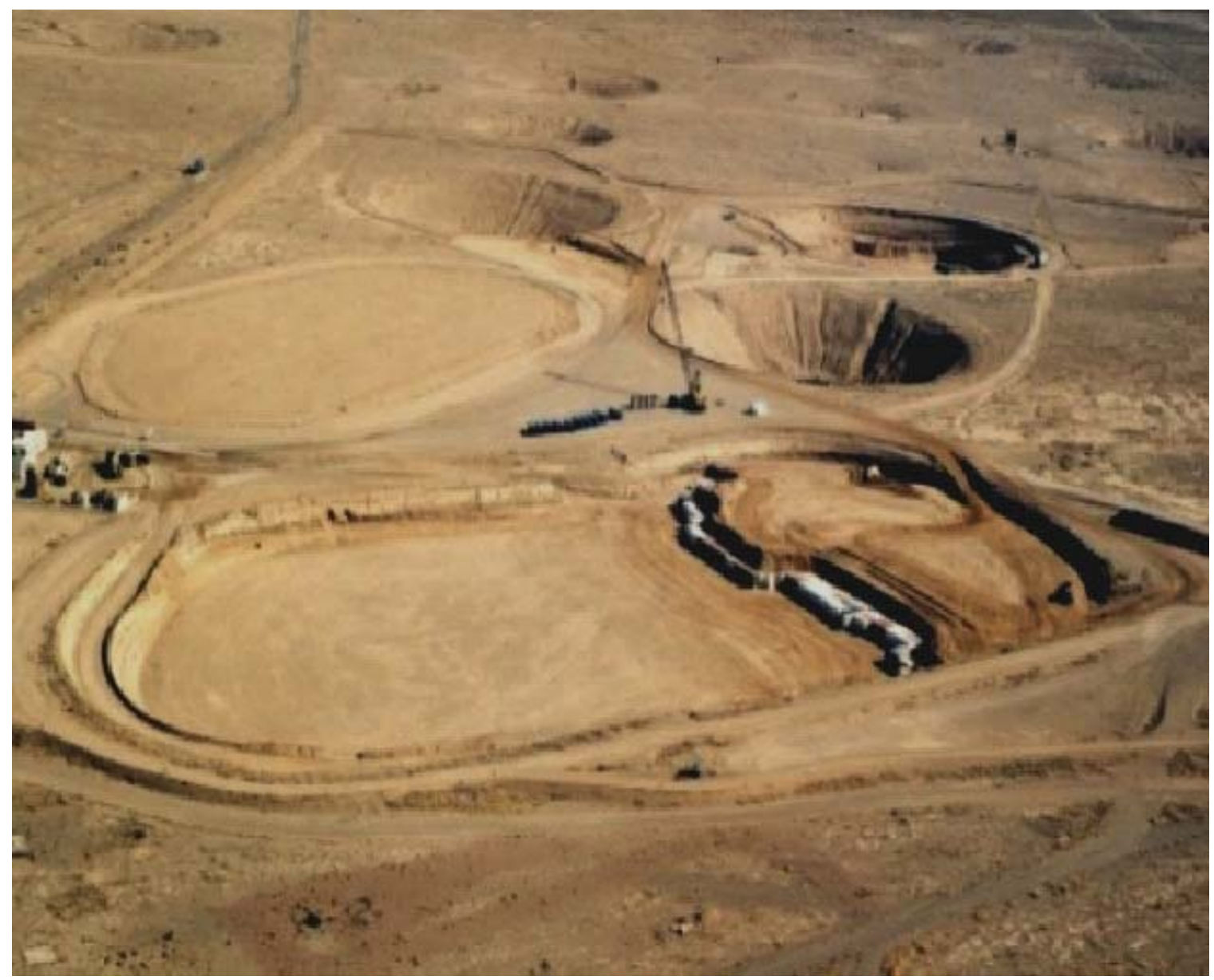

Area 3 Radioactive Waste Management Complex, Nevada Test Site 
This page intentionally left blank 


\subsection{Waste Characterization}

Generators must characterize waste destined for disposal at NTS. ${ }^{6.16}$ When similar requirements are listed in separate regulations, the most stringent shall be met. ${ }^{7.5}$ Waste will not be accepted until the generator, through sampling and analysis, process knowledge (PK), or a combination of both, demonstrates the waste to be LLW that meets the WAC requirements in Section 3.0. For waste characterized as MW, generators must demonstrate that the MW meets the applicable Title 40 CFR LDR and WAC. Generators shall characterize waste with sufficient accuracy to permit proper segregation, treatment, storage, and disposal. ${ }^{6.16}$ The characterization methods and procedures employed by the generator shall ensure that the physical, chemical, and radiological characteristics of the waste are recorded and known during all stages of the waste management process. ${ }^{6.16}$ Methods selected by the generator for waste characterization shall undergo a documented peer review. ${ }^{7.5}$ The Data Quality Objectives (DQOs) process, or a comparable process, shall be used for identifying characterization parameters and acceptable uncertainty in characterization data.

Generators must prepare and submit a WP for each waste stream which provides NNSA/NSO with a summary of waste characterization information. ${ }^{6.76227 .5}$ Generators shall provide waste characterization documentation that supports the WP (see Appendix E for radiological requirements) to NNSA/NSO for review during facility evaluations or upon NNSA/NSO request.

Waste characterization documentation shall be traceable to the WP and disposal packages. ${ }^{7.5}$ Isotopic distributions and corresponding activity concentrations shall be traceable to the package. ${ }^{7.5}$ Traceability to a parcel level shall be required if characterization is being conducted at that level (e.g., individual sealed sources, bags, or components characterized on an individual basis, but packaged together). Waste characterization may be conducted using PK, sampling and analysis, or a combination of both. The following sections provide specific information and requirements for these characterization methods.

\subsection{Process Knowledge}

PK is a characterization technique that relies on the generator's knowledge of the physical, chemical, and radiological properties of the materials associated with the waste generation processes. It includes knowledge of the fate of those materials during and subsequent to the process, and the associated administrative controls. PK sources include, but are not limited to, the following programmatic and waste stream-specific components:

- historic records, including historic analytical data

- facility maps delineating waste generation areas

- description of waste generating operations

- $\quad$ system descriptions 
- plans and drawings

- areas and/or buildings where each waste stream is generated

- material inputs, including MSDSs

- manufacturing specifications

- mass balance documentation

- literature searches

- living memory(documented interviews)

- laboratory notebooks and project reports

- process logs and batch records

- procedures

Historical data should be routinely verified through controlled analytical methods such as verification sampling and analysis; however, if the data can successfully undergo a full validation, this verification may not be necessary.

When PK relies on living memory, the individual's knowledge must be documented and signed by both the interviewer and the interviewee. ${ }^{7.5}$ For telephone interviews, a statement outlining relevant information must be signed by the interviewer (and interviewee, if possible).

PK can be used for waste characterization in lieu of sampling and analysis if the generator's PK is of sufficient detail to qualify as acceptable. Acceptable PK is based on detailed information on the waste obtained from existing waste analysis data, studies on similar waste generating process(es), or detailed information relative to the properties of the waste that are known due to site-specific and/or process-specific factors.

Generators shall conduct a documented evaluation of compiled PK sources used for waste characterization. ${ }^{7.10}$ The generator's evaluation shall identify uncertainties, inconsistencies, limitations, and usefulness.

\subsection{Sampling and Analysis}

Generators shall ensure that all data be scientifically valid, defensible, and of known precision and accuracy to identify the physical, chemical, and radiological properties of the waste. ${ }^{7.7}$ When waste streams are characterized by sampling and analysis, the process shall be controlled and documented. ${ }^{6.24}$ Propagation of error throughout the sampling and analytical process shall be evaluated and considered when ascertaining usability of data for characterization of waste. ${ }^{6.16}$ Generators should determine the appropriate analysis (total vs. TCLP) for RCRA hazardous and UHC determinations. These results shall be reported in the waste profile on Table B-1 (page 4-5). ${ }^{7.5}$ See the profile instructions for further details on reporting sampling results.

Generators shall demonstrate that controls are in place to trace each sample number to a specific package number. ${ }^{7.5}$ All sampling and analysis efforts, 
including verification and confirmatory sampling, should include screening analyses such as gamma spectroscopy, gross beta, and gross alpha.

NNSA/NSO may evaluate sampling and analysis documentation to ensure that: 1) samples will be representative of the waste inventory, 2) appropriate analytical procedures are used, and 3) sufficient quality controls have been established to allow measurement and documentation of data quality.

\subsubsection{Data Validation}

Data validation is a comprehensive analysis and review of analytical data conducted against a set of predetermined criteria and leading to the assignment of relative usability (i.e., completely usable, estimated value, unusable) for each analytical result. The validation criteria should be developed using the DQO process and depend upon the type(s) of data involved and the purpose for which the data are collected. Data shall be validated by technically qualified personnel who are independent of those performing the analyses.

When sampling and analysis is used as a method of characterization, data validation shall be conducted on a portion of chemical and radiological data per NTS waste stream, prior to use of the data for characterization purposes.

The WP instructions require completion of an analytical results summary (Table B-1) for inclusion in the WP. As required by the above paragraph, data validation will be performed on a portion of the data used to complete the table. If in subsequent sampling events, variations of analytical results remain less than 80 percent of the applicable regulatory threshold, revision of Table B-1 is not required. If the results ever exceed 80 percent of the regulatory threshold, it will be necessary to revise the table and submit appropriate validation summary reports (case narratives) for the values entered in the revised table.

Validation summary reports shall cite the guidelines or procedures used to validate the data and shall include, at a minimum:

- Method/Analysis-general discussion of the data set, including preparation/dilutions, initial and continuing calibration, holding times.

- Method blank Analysis

- LCS Analysis

- Surrogate Spike Recoveries 
- Data Qualifier Codes

- Discussion/Statement of data quality 
TCLP Metals:

Arsenic

Barium

Cadmium

Chromium

Lead

Mercury

Selenium

Silver

TCLP Volatiles

Benzene

Carbon

Tetrachloride

Chlorobenzene

Chloroform

$1,4-$

Dichlorobenzene

1,2-Dichloroethane

Methyl ethyl ketone

Pyridine

\section{TCLP Volatiles}

Tetrachloroethylene

Trichloroethylene

Vinyl chloride

Dichloroethylene

Table B-1 Analytical Results

$\begin{array}{cc}\text { Statistical } & \begin{array}{c}\text { Upper } \\ \text { Confidence } \\ \text { Mean }\end{array} \\ \text { Limit }\end{array}$
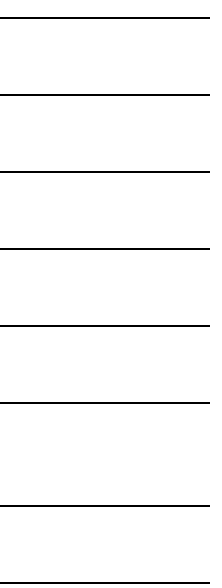

\section{TCLP Pesticides and Herbicides:}

Chlordane

2,4-D

Endrin

Heptachlor and

Hydroxide

\section{TCLP Pesticides and Herbicides:}

Lindane

Methoxychlor

Toxaphene

2,4,5-TP (Silvex)
Upper

Confidence Limit

\section{Pentachlorophenol}
Nitrobenzene
$2,4,5-$
Trichlorophenol
$2,4,6-$
Trichlorophenol
Hexachloroethane
o-Cresol
p-Cresol
m-Cresol
Cresol
Hexachlorobenzene
Hexachloro-1,3- butadiene

tatistical
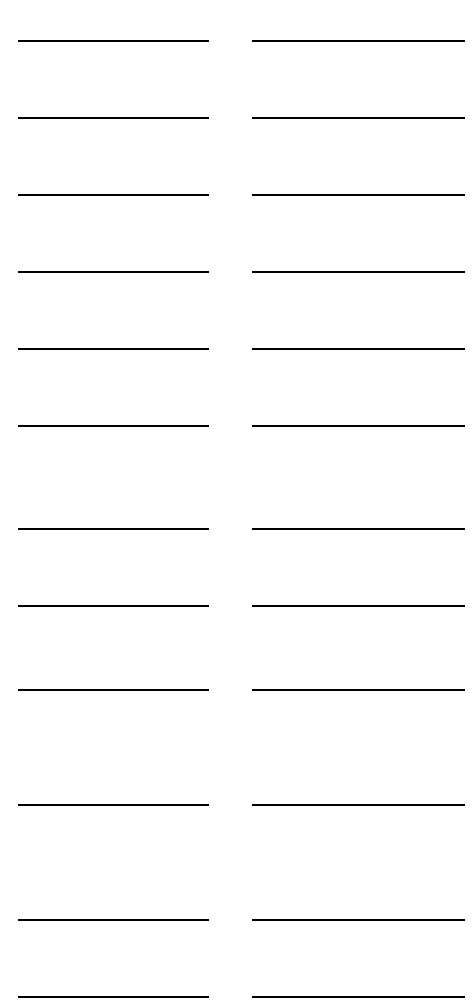

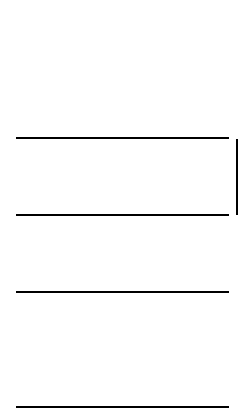


This page intentionally left blank. 


\section{0 \\ Quality Assurance Requirements \\ for \\ Waste Certification Program}

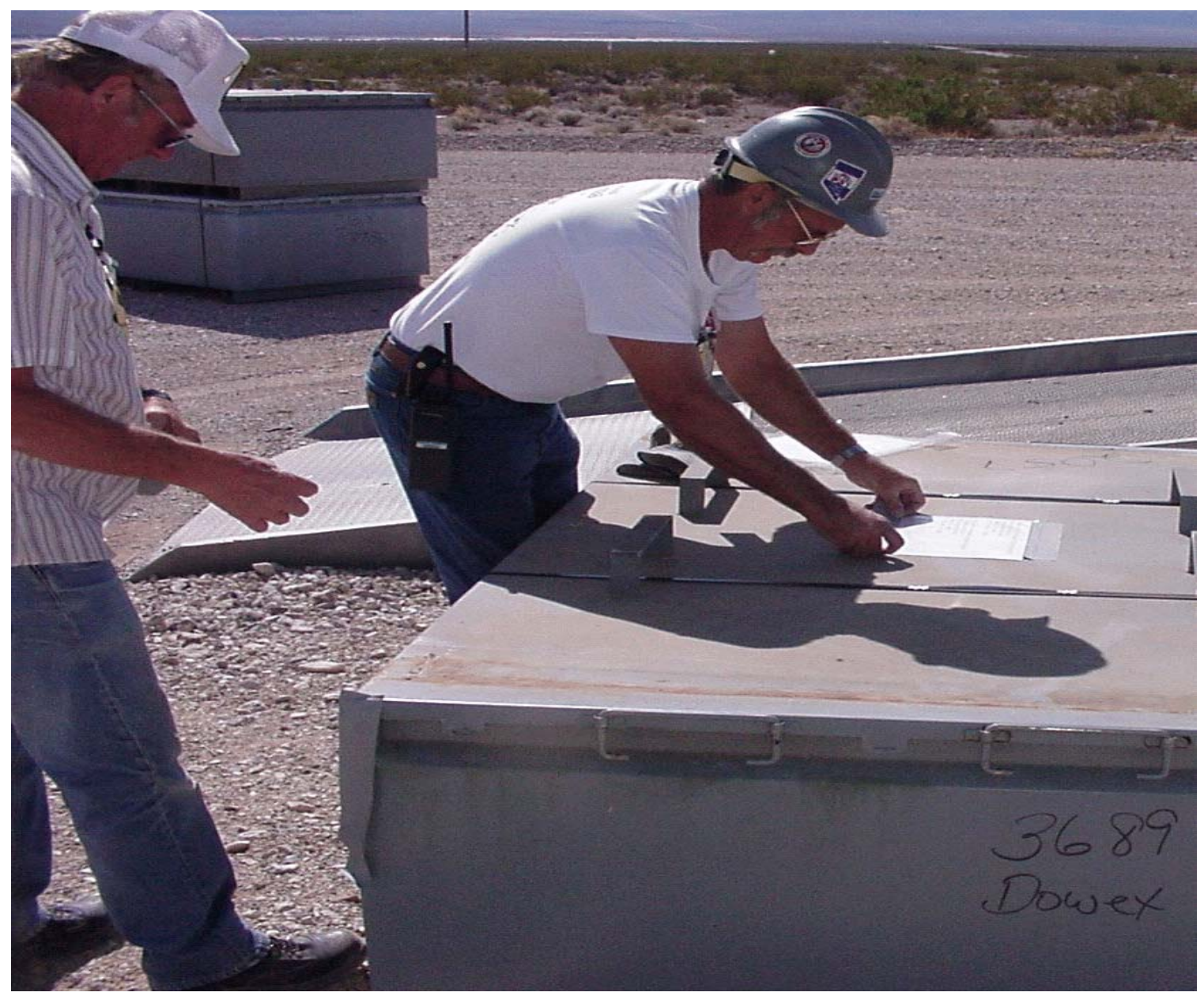

Area 5 Radioactive Waste Management Complex Workers Labeling Boxes, Nevada Test Site 
This page intentionally left blank. 


\subsection{Quality Assurance Requirements for Waste Certification Program}

RWAP quality requirements are written in accordance with DOE Order 414.1, "Quality Assurance"; Title 10 CFR 830.122, "Quality Assurance"; and NNSA/NSO Policy unless otherwise noted by superscript.

Generators shall develop, approve, and maintain a QAP demonstrating compliance to the NTSWAC: DOE Order 435.1, "Radioactive Waste Management"; DOE Order 414.1, "Quality Assurance”; and/or Title 10 CFR, 830.122, "Quality Assurance."

Generators shall submit a controlled copy of their approved QAP to the RWAP Manager. Generators maintaining a controlled WCPP on file with RWAP are not required to submit their site QAP. Generators with an approved WCPP that choose to utilize their site QAP in lieu of maintaining a WCPP must notify the RWAP Manager and formally submit their site QAP for review and approval.

Generators must complete a NIC and submit it to the RWAP Manager. The NIC must describe and/or reference each site's quality-affecting procedures, processes, or methods that demonstrate compliance and/or implement the specified NTSWAC criteria. Examples of procedures, processes, or methods may include:

- Plans and procedures from supporting organizations that satisfy the quality criteria in Section 5.0 of the NTSWAC.

- Waste characterization data.

- Documents demonstrating compliance to the waste criteria and packaging criteria in Section 3.0 of the NTSWAC.

- Documents assuring conformance to marking, labeling, electronic reporting, and forms requirements.

An electronic copy of the NIC and instructions are available from NNSA/NSO.

The WCO shall perform an annual review of the NIC to ensure that procedures, processes, and methods referenced in the NIC are current. Upon completion of the review, the WCO shall sign and submit a current NIC to the RWAP Manager.

\subsection{Program}

Generators must develop an organizational chart specific to the waste management and support organizations. The organizational chart must depict the organizational structure, functional responsibilities, levels of authority, and interfaces necessary to manage the waste certification program. The chart must identify the organizations that generate, characterize, package, inspect, assess, ship, and perform support functions (i.e., procurement, document control, RCRA oversight, and training). 
Each generator shall designate a WCO and alternate(s), if applicable, who are responsible for verifying implementation of the WCPP or QAP. The WCO must ensure that the waste certification processes, including waste, waste packages, supporting data, and waste shipments, comply with the requirements of the NTSWAC. The alternate WCO must report to the primary WCO for certification activities. The organizational structure must ensure the independence of the WCO, alternates(s), and package certifiers from the waste generator and allow for direct access to a management level (including the local DOE field office), having sufficient authority and organizational freedom, if necessary, to ensure compliance with the LLW program.

Generators may delegate the responsibility for signing the PCL to Package Certifiers; however, the Package Certifiers must report directly to the WCO for certification activities.

\subsection{Personnel Training and Qualification}

Personnel shall be trained and qualified to perform their assigned functions and tasks. The level and type of training shall be evaluated and documented. Training shall be commensurate with the importance of the task and the activities affecting compliance with the NTSWAC waste certification activities. Personnel must be provided training to ensure that job proficiency with established requirements is maintained. Methods and records shall be specified to ensure training of personnel is current and maintained.

\subsection{Quality Improvement}

Process controls to detect and prevent quality problems and verify conformance to specified requirements must be established and implemented. Performance of quality improvement processes must be documented.

Control of nonconforming components and processes must provide for the identification, documentation, evaluation, segregation (when practical), disposition, and notification to the affected organizations, including the WCO. Nonconforming components must be conspicuously labeled, tagged, or otherwise marked to ensure removal from the waste certification process and prevent inadvertent use.

The disposition of nonconforming components, services, and processes must be reviewed for technical justification and disposition by authorized personnel. When nonconforming conditions are identified that affect the quality of previously shipped waste, NNSA/NSO must be notified.

A process shall be established for the identification and timely correction of quality problems. The root cause, corrective action, action to prevent recurrence, and estimated completion date must be documented. The WCO and appropriate levels of management must be involved in the corrective action process and the corrective actions tracked until successful resolution can be demonstrated. 


\subsection{Documents and Records}

Activities affecting the quality of the waste certification program must be prescribed and performed in accordance with written instructions, procedures, or drawings and available to those performing the work. A document control system shall be established to assure that these documents are prepared, reviewed, approved, controlled, and revised.

The WCO shall document the review and concurrence of procedures (including revisions) critical to waste certification activities (i.e., generation, packaging, inspection, characterization, certification, etc.).

The records system shall be defined and implemented in accordance with written instructions, procedures, or other documentation.

Records documenting compliance with waste certification criteria shall be specified, prepared, reviewed, and signed by authorized personnel.

Records shall be compiled into a records management system that includes provisions for transmittal, distribution, retention, handling, correction, disposition, and retrievability. Completed records must be protected from damage, loss, and deterioration.

The generator shall maintain records for time periods equivalent to on-site records retention requirements, but not less than three years (or for time periods designated by other regulatory authorities).

\subsection{Work Processes}

Work must be planned and performed to established technical standards and administrative controls using approved instructions, procedures, or other appropriate means.

Processes important to waste certification activities must have controls or verification steps identified as part of the operating procedures.

Controls shall be established to ensure that the traceability of waste from the point of generation through shipment is maintained. Waste characterization documentation must be traceable to the exact package in which waste was placed. Waste containers must be controlled through the life cycle of the component (e.g., receipt, handling, storage, packaging, and shipping) to prevent damage, loss, or deterioration.

Components used in the certification process such as waste containers, liners, sorbents, and solidifiers shall be controlled to ensure that only correct and acceptable items are used. Identification must be maintained on items or documents traceable to the items. 
Measuring and Test Equipment (M\&TE) used for process monitoring or data collection must be uniquely identified, controlled, and calibrated. Records of calibration shall be maintained, traceable to the equipment, and the equipment suitably marked to indicate calibration status. The M\&TE marking must include a unique identification, date of calibration, calibration due date, and any limitations. Calibration equipment for M\&TE shall be traceable to a nationally recognized standard or equivalent means to assure accuracy.

Testing and validation of computer programs and verification of data results from those programs (i.e., PSDR data, radioactivity calculations) shall be conducted and documented.

\subsection{Design}

Structures, Systems, and Components (SSCs) designed and/or constructed to ensure that waste will satisfy certification requirements must be designed using sound engineering/scientific principles and standards and performed in accordance with established design processes.

Design adequacy of SSCs shall be verified or validated by qualified personnel other than those who initiated the design. Verification and validation of SSC designs must be completed and approved prior to implementation of the design or design changes.

Design interfaces shall be identified and controlled. Waste generators shall document their review of product or process designs (e.g., waste containers, sorbents, waste treatment operations) when performed by others (e.g., suppliers or other generators) to ensure that they conform to established requirements and enduse application.

Design changes shall be approved commensurate with the same control measures that were applied to the original design.

\subsection{Procurement}

Components and services critical to the waste certification program must be procured under a controlled and documented system. Procurement documents shall identify applicable technical requirements such as drawings, specifications, codes, standards, regulations, tests, inspection and acceptance criteria, and certification records.

Procurement documents shall be reviewed and approved by authorized personnel to ensure that they contain appropriate references and technical requirements. Changes to procurement documents must receive the same degree of review and approval as the original documents. 
Selection of suppliers providing components and services critical to the waste certification program must be evaluated and selected on the basis of specified criteria (e.g., waste packaging). The methods of evaluation (i.e., audits, surveillance, source inspection, receipt inspection, third party audits) shall be established and provide adequate confidence that the selected supplier can meet the established requirements. When third-party audits are used to qualify a supplier, a documented evaluation of the report must be performed by a qualified Lead Auditor identifying the activities, findings, conclusions, and basis for qualification.

Suppliers of components (e.g., off-the-shelf sorbents) that are tested or verified by the purchasing organization for conformance to technical requirements may not need to be evaluated (audited), provided the testing demonstrates the procured component conforms to design requirements. Conformance testing must be documented.

A process to ensure approved suppliers continue to provide acceptable components and/or services must be established and implemented. Methods of evaluation shall be specified and documented.

\subsection{Inspection and Acceptance Testing}

Inspection and testing of components, services, and processes critical to the waste certification program must be conducted using established acceptance and performance criteria. Inspections must be performed by qualified personnel having no responsibility for the work activity being inspected.

Receipt inspections must be performed to verify conformance of components received to the procurement documents and design criteria.

In-process inspections, including waste container pre-use inspections and waste packaging activities, shall be conducted throughout the waste certification process.

Final inspections shall be conducted to verify conformance of the waste, containers, and waste certification process to the NTSWAC prior to shipment of the waste.

Records of inspection shall identify the type of inspection, component(s), services, or process inspected, date of inspection, inspector, inspection results, and action taken if nonconforming conditions are identified.

\subsection{Management Assessment}

Management of Waste Certification Programs shall periodically assess their management processes to ensure that conditions which could preclude the organization from achieving its objectives are identified and corrected. Management assessments shall be documented in a final report and issued to appropriate organizations, including the WCO for review. 


\subsection{Independent Assessment}

Waste certification programs must be independently assessed (audit and surveillances) annually to verify compliance with applicable quality program requirements and to promote process improvement. A signed copy of the independent assessment report shall be forwarded to the RWAP Manager upon completion of the assessment.

Surveillances may be accumulated and used in lieu of the annual audit provided they have been conducted within 12 months of the last annual audit or surveillance rollup, and encompass the entire waste certification program and supporting elements. When surveillances are used as the annual assessment, a final report shall be prepared and approved by a qualified Lead Auditor identifying the activities, conclusions, findings, and corrective actions initiated during each surveillance.

Audits and surveillances shall be planned, scheduled, and conducted in accordance with a documented and approved process. The WCO and/or supporting oversight organizations shall schedule and conduct periodic surveillances of activities critical to the waste certification program.

Personnel performing assessments must be qualified and knowledgeable in the areas being assessed. Assessment personnel must be independent of the assessed areas and have sufficient authority and freedom to effectively carry out the assessment activities.

Results of assessment activities (audits and surveillances) must be documented, approved, and reported to responsible management, including the WCO. Deficiencies identified during an assessment activity shall be tracked until acceptable resolution is achieved and verified. 


\section{0}

\section{Waste Transportation and Receipt Information}

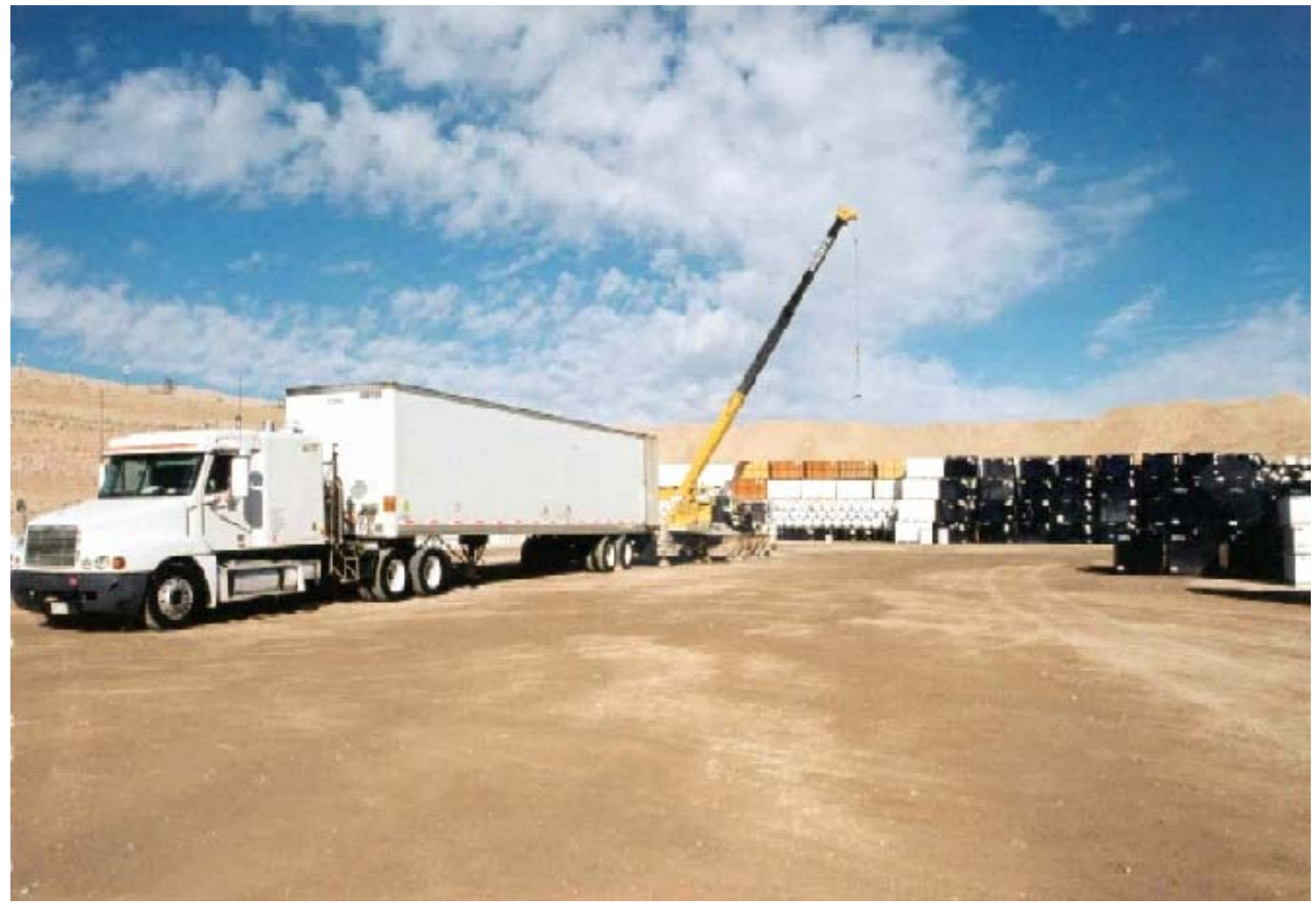

Waste placement in the Area 5 Radioactive Waste Management Complex, Nevada Test Site 
This page intentionally left blank 


\subsection{Waste Transportation and Receipt Information}

This section provides general guidelines that generators follow to expedite waste transportation and receipt.

\subsection{Shipment Scheduling and Limitations}

NTS Operations may impose schedule limitations on waste profiles that have specific handling and/or processing requirements. "Classified Waste," ALLW, and MW shipments may have a shipment frequency limitation to accommodate additional processing needs. (For example, classified shipments may be limited to four shipments per day per generator, with a generator limited to Tuesday and Thursday arrivals.) All scheduling limitations must be made through NTS Operations. $^{7.6}$ Containers that are to be returned to the generator (e.g., intermodal containers, shipping casks, etc.) may have shipment scheduling limitations (i.e., due to weather conditions), and this schedule may be modified and/or suspended as warranted.

Generators shall provide NTS Operations with a monthly shipment schedule by the third Friday of each calendar month, estimating shipments for the following month $^{7.6}$. This schedule is to include:

- estimated number of shipments

- estimated arrival dates

- profile numbers

- type and quantity of packages

- special handling concerns

NTS Operations shall be notified of deviations from the schedule. Requests for rescheduled or additional shipments are subject to concurrence by NTS Operations.

NTS Operations may occasionally extend operating hours (i.e., Fridays). During these extra periods, NTS Operations will designate which types of shipments they will receive on the given date (e.g., on the third Friday in September, the NTS will accept cargo containers of standard LLW and DOT nonregulated bulk).

\subsection{Shipping Arrangements}

After a generator secures written approval from the NNSA/NSO AMEM to send waste to an NTS RWMC, the generator shall contact BN to arrange for transfer of the waste and accompanying records. ${ }^{7.5} \mathrm{BN}$ coordinates waste shipment transfers at NTS. 


\subsubsection{Waste Receipt and Handling at NTS}

To expedite waste receipt and handling at NTS, waste generators shall, at a minimum, comply with the following: ${ }^{7.6}$

- Prior to departure of a waste shipment to the NTS, the generator shall attach security seals to the shipping trailer's door latches or to each package if not enclosed in a trailer.

- The generator shall enter the following pre-notification information on the BN HAZTRAK database. ${ }^{7.6}$ If the generator is unable to enter information on the BN HAZTRAK, fax the NTS Advance Shipment Notification (see Appendix C.4) to BN at (702) 295-6852.

Shipments to the NTS must be entered in the BN HAZTRAK database prior to 1500 NTS local time, at least one working day prior to shipment arrival (e.g., shipments scheduled to arrive Monday must be entered in HAZTRAK by 1500 NTS local time on the previous Thursday). ${ }^{7.6}$ If the shipper is faxing the NTS advance shipment notification to BN, the fax must be received prior to the cutoff time and date. ${ }^{7.6}$ For "classified waste," having classified shipping documents, generators shall contact Wackenhut Services at (702) 295-7028. ${ }^{7.6}$ For all shipments, the following information must be provided: ${ }^{7.6}$

- Date and time shipment departed generator site

- Estimated date and time of arrival (ETA) at NTS

- Shipment number, shipper's name, shipper's contact number

- Carrier, driver's name (must be a U.S. Citizen), driver's license number and state (information must be legible)

- Trailer number, seal number(s), DOT "Proper Shipping Name(s)"

- Number of packages, package type (boxes, drums, cargo containers, burrito wraps, etc.), and gross weight

- Waste stream number and description of waste

If the shipment's ETA should change, the generator must notify BN and shall enter the changes on the BN HAZTRAK database at the earliest opportunity and provide the new ETA. ${ }^{7.6}$ Generators unable to update 
information on the BN HAZTRAK shall notify BN by phone at (702) 295-6811.

The majority of the above information can be found on the "Bill of Lading."

- For waste shipments containing regulated asbestos, the 7-day advance notification form must be faxed to NNSA/NSO; see Section 3.1.15.

\subsubsection{Consignment of Shipments}

Consign waste shipments to:

Bechtel Nevada

For U.S. Department of Energy

Waste Management

Nevada Test Site - Zone 2

Mercury, NV 89023

Because unclassified and classified shipments are processed differently, they must be shipped separately (i.e., on different trailers and have different shipment numbers and separate shipping papers). ${ }^{7.6}$ This also applies to ALLW and MW (i.e., shipped separately from standard LLW). Under small-volume conditions, combined shipments can be arranged by contacting BN.

\subsubsection{Receiving Hours}

The hours for receiving waste at the RWMC are from 0700 to 1400 hours, Monday through Thursday, except holidays. Tractor-trailers arriving between 0700 and 1400 hours (Monday through Thursday) will be allowed to remain at the Area 3 or 5 RWMC until their delivery is complete. If a shipment arrives between 1400 and 0700 hours, tractortrailers will be required to exit the NTS to return after 0700 hours for off- loading. Shipments may be subject to off-loading delays at any time due to NTS operational schedules.

All shipments to Area 3 or Area 5 RWMC will be verified against a shipment tracking list by a Security Police Officer (SPO) at the NTS main gate. If the shipment tracking number is listed, the shipment will be authorized to enter the NTS. If the shipment is not listed, the SPO will attempt to contact an RWMC official to verify the shipment to authorize entry. 


\subsection{Shipping Documentation}

The following records are required:

\subsubsection{Accountable or Special Nuclear Material Shipments}

For accountable or special nuclear material shipments, a "Nuclear Material Transaction Report" (DOE/NRC Form 741) shall be completed for transfers of nuclear material between facilities having differing Reporting Identification Symbols. ${ }^{6.3}$ Transaction reports shall be sent to: Bechtel Nevada, P.O. Box 98521, Mail Stop NTS 403, Las Vegas, NV $89193-8521$. Forms may be faxed to (702) $295-6852 .^{7.6}$ Reports should be received at the RWMC prior to the shipment arrival. ${ }^{6.3}$ For additional information, call the RWMC at (702) 295-6811. Contact Wackenhut Services at (702) 295-7028 if the shipping documentation contains classified information.

Generators shipping waste that require a DOE/NRC Form 741 shall complete and fax a "Nevada Test Site - Waste RIS VAB Accountable Nuclear Materials Authorization to Ship Waste" form to (702) 295-6337 seven days prior to shipment. Authorization to ship from NTS MC\&A must be obtained prior to shipping the waste to the NTS. An electronic copy of the "Nevada Test Site - Waste RIS VAB Accountable Nuclear Materials Authorization to Ship Waste" form is available on the NNSA/NSO website at http://www.nv.doe.gov/emprograms/environment/wastemanagement/rw ap.aspx.

\subsubsection{DOT-Regulated Shipments}

For materials regulated by DOT, complete shipping papers with shipper's certification, as required by Title 49 CFR, must accompany each shipment.

A "Uniform Hazardous Waste Manifest" or equivalent state-ofgeneration manifest, accompanied by the appropriate documentation, shall be used when shipping MW. ${ }^{3.43 .12}$ For on-site shipments of MW, an on-site Waste Manifest may be used. The waste profile(s) number associated with the package(s) must be entered on the Uniform Hazardous Waste Manifest or equivalent.

\subsubsection{PSDR Submittal}

The original completed and signed PSDR, or the original of an equivalent, shall accompany each shipment. ${ }^{6.27 .6}$ An electronic version of the PSDR shall be transmitted to BN prior to shipment arrival (E-mail address: wmdata@nv.doe.gov). ${ }^{7.6}$ Shipments shall not be accepted if an 
electronic PSDR is not on file.

\subsubsection{Additional Certification Statements}

An appropriate LLW Certification Statement shall be signed by an authorized WCO or Alternate WCO for LLW (see next page for an example of the required LLW Certification).

An appropriate LDR Certification Statement shall be signed by an authorized WCO or Alternate WCO for MW (see Title 40 CFR 268.7 for information required to be included in an LDR certification/ notification).

Low-Level Waste Certification

I certify that containers:

(Container I.D. number(s))

do not contain hazardous waste as defined in Title 40 CFR 261 or (state-ofgeneration) hazardous waste regulations:

(1) according to the results of tests performed in accordance with the requirements as specified in Subpart C of Title 40 CFR 261: and/or

(2) according to the supporting documentation provided to me about the materials and processes that produced this waste.

To the best of my knowledge, I believe the information I have submitted is true, accurate, and complete.

Generator Waste Certification Official (print name/sign) Date

The LDR certification/notification is required for the initial shipment of the waste stream or when the waste profile/LDR information changes.

\subsection{Waste Transportation}

Waste shipments consigned to BN shall be made in accordance with applicable DOE, DOT, EPA, state, and local hazardous waste regulations and requirements. Generators are responsible for the evaluation of the motor carriers used for transporting radioactive waste. Motor carrier documentation (e.g., past carrier performance, prior evaluations, accident history, vehicle maintenance, etc.) should be reviewed to ensure that the carrier is in compliance with Title 49 CFR, state, and local transportation requirements. If carrier performance has been determined to violate federal, state, or local transportation safety regulations, a 
demonstration of corrective action may be required. Failure to initiate corrective action may result in waste refusal at the NTS.

NNSA/NSO shall be notified when (1) the motor carrier(s) is being evaluated; (2) the motor carrier route selection is being reviewed; (3) a motor carrier discrepancy, noncompliance, or inadequate performance has been identified; or (4) there is a transportation incident or emergency situation. ${ }^{7.6}$ This notification will keep NNSA/NSO personnel informed of generator transportation plans, activities, and issues. NNSA/NSO personnel will be able to use the information provided to inform stakeholders of transportation activities of radioactive LLW

destined for the NTS. NNSA/NSO personnel may request to participate in the review of transportation-related information. NNSA/NSO may provide driver advisories to inform generators of local driving conditions (e.g., road construction, detours, safety issues). The generators will be responsible for providing carriers with driver advisories.

Generators shall ensure that a National Environmental Policy Act (NEPA) analysis (Title 10 CFR 1021) of the potential waste transportation impacts is completed prior to waste shipment. Transportation of the waste to the NTS should conform to a supporting finding or decision based on the impact analysis. NNSA/NSO encourages approved generators and their carriers to review route selections. Transportation of LLW and MW to the NTS must avoid Hoover Dam and Las Vegas. ${ }^{75}$ Routes selected are required to minimize radiological risk. Information on accident rates, time in transit, population density, construction activities, and time of day must be considered when determining radiological risk.

\subsection{Waste Receipt and Records}

$\mathrm{BN}$ will be responsible for inspecting radioactive waste shipments upon arrival and maintaining shipment records for NNSA/NSO. BN RWMC will take receipt of the waste after it has been unloaded, inspected, verified, and accepted by RWMC personnel.

\subsection{Funding and Forecasting}

For information regarding funding and forecasting requirements, contact NNSA/NSO WMD at (702) 295-0672.

\subsection{Disposition of Noncompliant Conditions}

NTS RWMC and RWAP personnel are responsible for identifying and documenting noncompliance issues (i.e., physical or documentation errors) discovered when conducting MW and LLW receipt and disposal activities. MW and radioactive waste shipments received at the NTS that are not in compliance with requirements may be returned to the generator facility or require resolution 
from the generator.

NNSA/NSO shall be notified of waste shipment noncompliance issues. Appropriate action will be initiated based upon the type of the noncompliance and the established program requirements. Generators may be charged for costs incurred for noncompliant waste shipments.

Generators shall work with NNSA/NSO and BN to ensure rejected shipments/containers of $\mathrm{MW}$ are returned to the generator or an alternate treatment, storage, or disposal facility within 60 days from the date of receipt at the NTS. ${ }^{7.5}$ Generators shall be responsible for dispositioning rejected wastes and coordinating transportation and manifesting back to the generator's site or an alternate facility.

\subsection{Waste Refusal}

BN personnel will be responsible for notifying the appropriate NNSA/NSO personnel regarding any refused radioactive or mixed waste shipments. Reasons for waste shipment refusal include, but are not limited, to failure to have:

- conforming package activity limits as specified in Section 3.2.2.

- sufficient funding transferred to BN to cover the cost of handling disposal, or storage.

- a DOE/NRC Form 741 on file at the NTS prior to the shipment's arrival.

- a signed certification statement accompanying the shipment.

- successful verification performed on the waste containers in accordance with the NTSWAC, NTS Waste Analysis Plan (WAP), and applicable procedures. 
This page intentionally left blank. 
Appendix A

\section{Waste Process \\ Flow Diagrams}


This page intentionally left blank. 


\section{Appendix A - Waste Process Flow Diagram}

The following diagram identifies key process steps. Operations and logistics may influence the order in which these activities are conducted. Technical support may be requested at any time by the generator (Section 2.5).
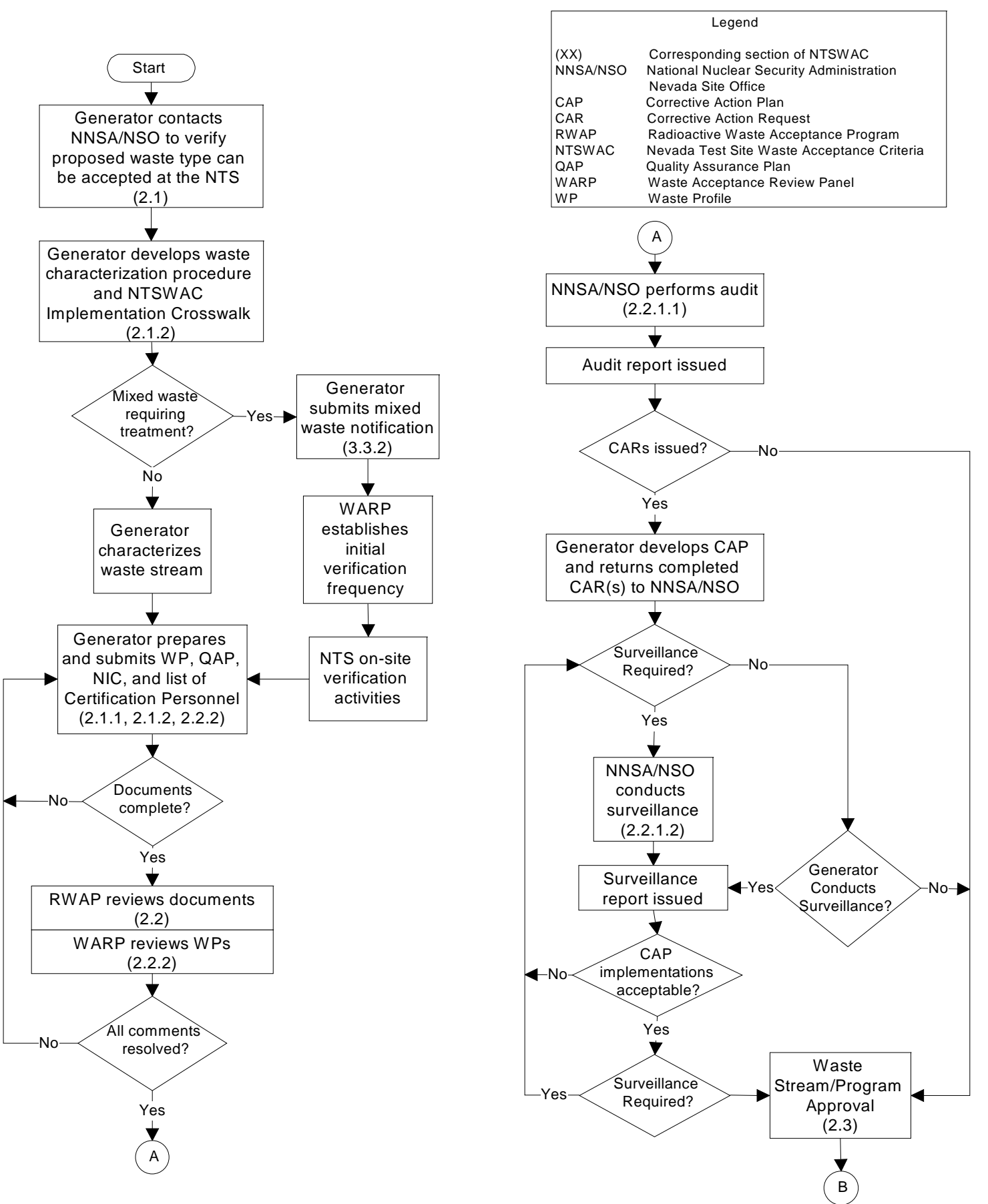


\section{Appendix A - Waste Process Flow Diagram (continued)}

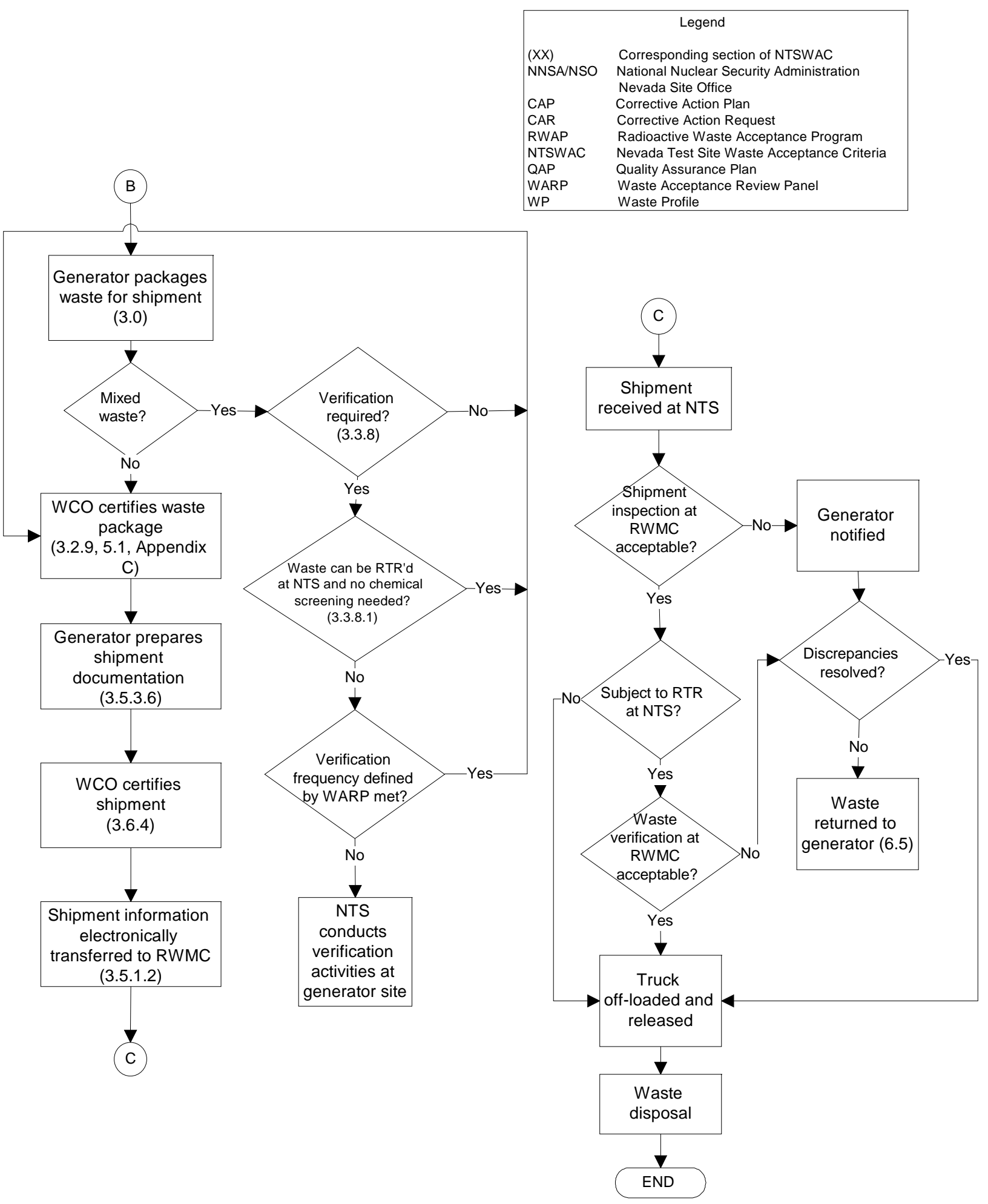




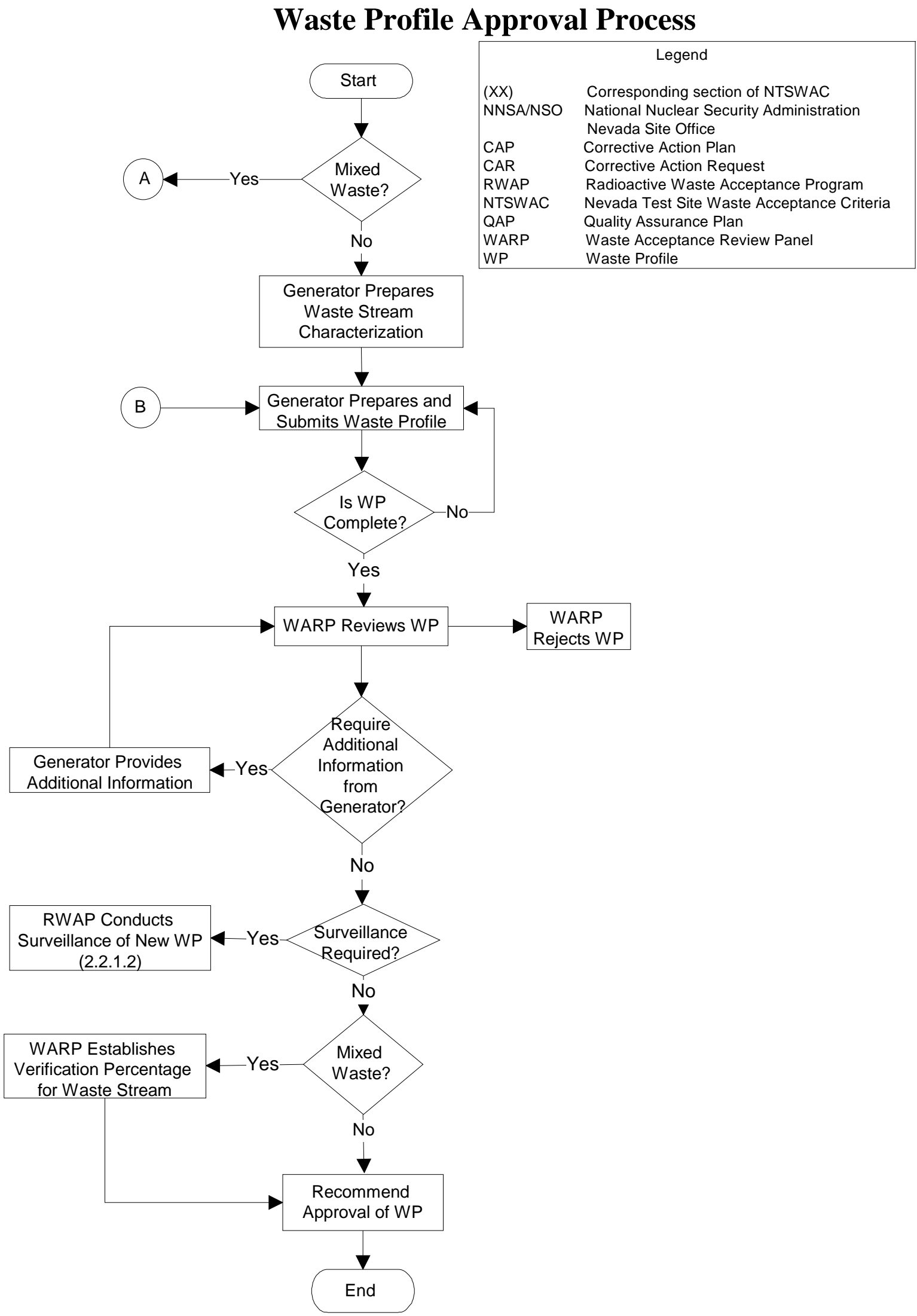




\section{Waste Profile Approval Process (continued)}

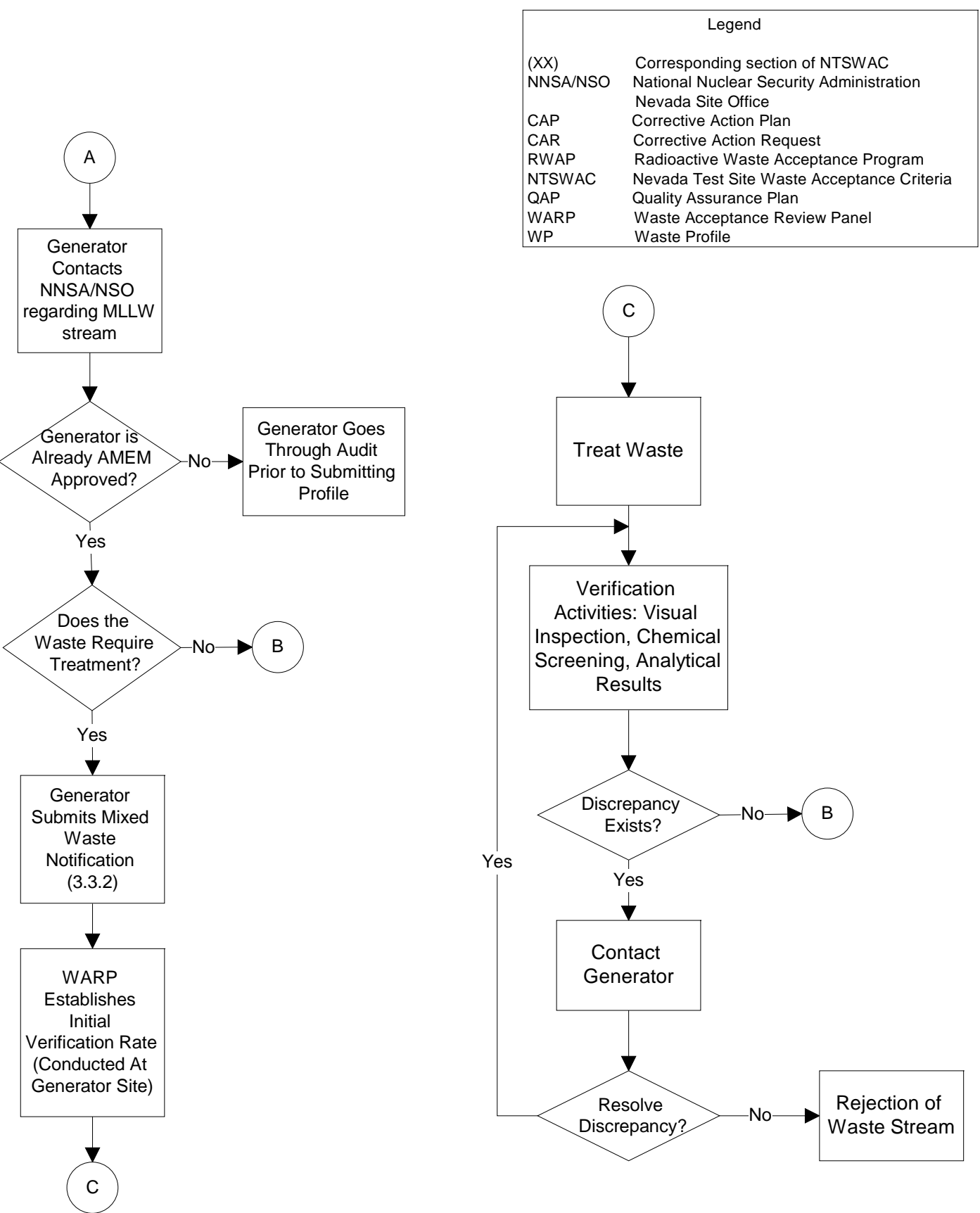




\section{Document and Personnel Changes}

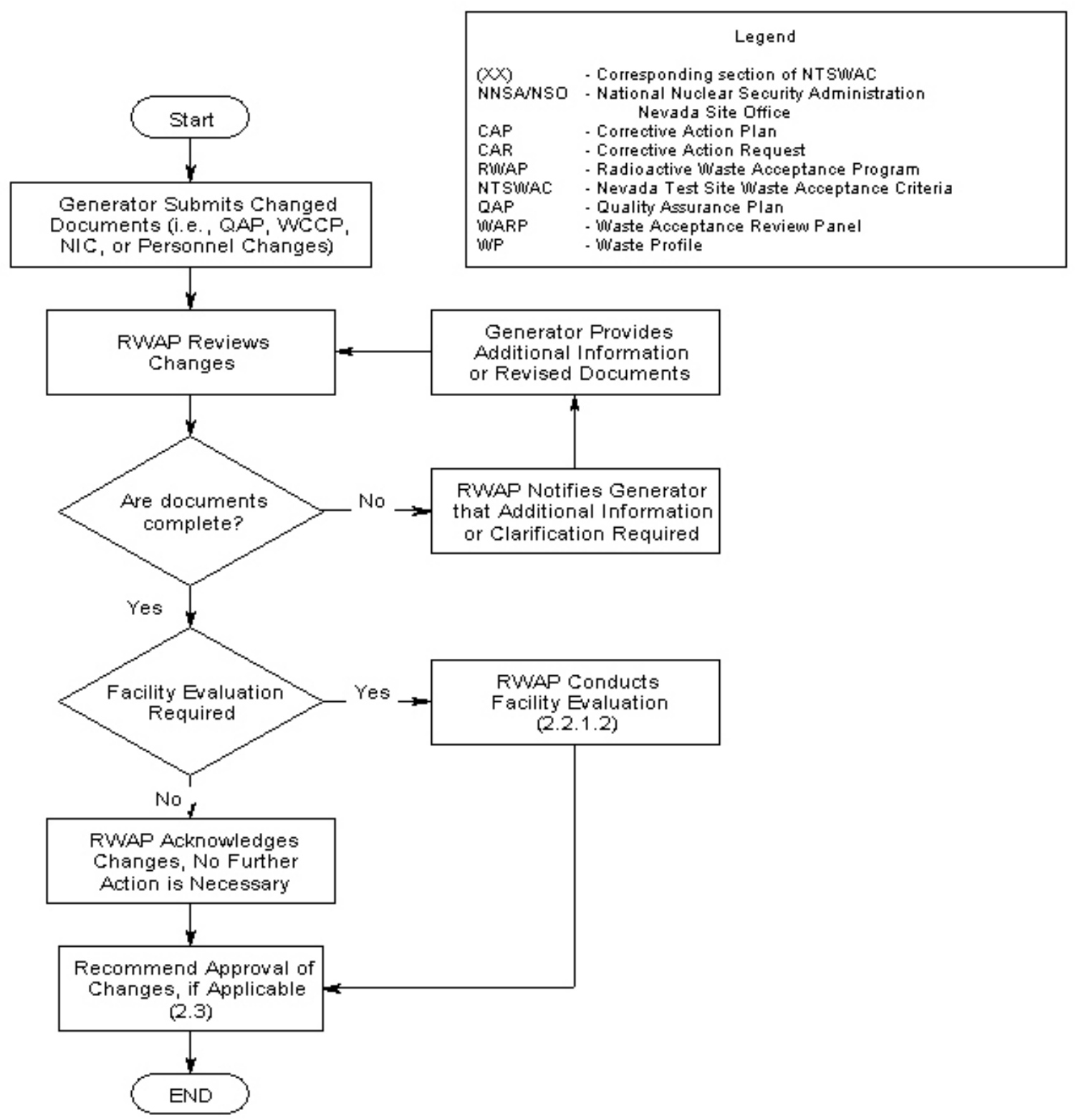


This page intentionally left blank. 


\section{Appendix B}

\section{Plutonium Equivalent Gram (PE-g) Radionuclide Conversion Factors}


This page intentionally left blank. 


\section{Plutonium Equivalent Gram (PE-g) Radionuclide Conversion Factors*}

* Note: For isotopes not having a direct PE-g conversion factor, the total activity shall be treated as $\mathrm{Pu}-239$ for alpha emission and as Cs-137 for beta/gamma emission.

\begin{tabular}{|c|c|c|c|c|c|}
\hline \multicolumn{2}{|c|}{$\begin{array}{l}\text { Nuclide CONVERSION } \\
\text { FACTORS ----PE-g / Bq }\end{array}$} & \multicolumn{2}{|c|}{$\begin{array}{l}\text { Nuclide CONVERSION } \\
\text { FACTORS ---- PE-g / Bq }\end{array}$} & \multicolumn{2}{|c|}{$\begin{array}{l}\text { Nuclide CONVERSION } \\
\text { FACTORS ---- PE-g / Bq }\end{array}$} \\
\hline Ac-224 & $1.12 \mathrm{E}-13$ & Au-194 & $8.69 \mathrm{E}-16$ & $\mathrm{Br}-80$ & $2.40 \mathrm{E}-17$ \\
\hline Ac-225 & $9.19 \mathrm{E}-12$ & Au-195 & $1.10 \mathrm{E}-14$ & $\mathrm{Br}-80 \mathrm{~m}$ & $3.34 \mathrm{E}-16$ \\
\hline Ac-226 & $1.12 \mathrm{E}-12$ & Au-198 & $2.79 \mathrm{E}-15$ & Br-82 & $1.30 \mathrm{E}-15$ \\
\hline Ac-227 & 5.70E-09 & $\mathrm{Au}-198 \mathrm{~m}$ & $4.12 \mathrm{E}-15$ & $\mathrm{Br}-83$ & $7.59 \mathrm{E}-17$ \\
\hline Ac-228 & $2.62 \mathrm{E}-13$ & Au-199 & $1.28 \mathrm{E}-15$ & $\mathrm{Br}-84$ & $8.22 \mathrm{E}-17$ \\
\hline Ag-102 & $2.87 \mathrm{E}-17$ & $\mathrm{Au}-200$ & $7.56 \mathrm{E}-17$ & C-11 & $1.04 \mathrm{E}-17$ \\
\hline Ag-103 & $4.97 \mathrm{E}-17$ & $\mathrm{Au}-200 \mathrm{~m}$ & $1.87 \mathrm{E}-15$ & C-14 & $1.79 \mathrm{E}-15$ \\
\hline Ag-104 & $6.05 \mathrm{E}-17$ & $\mathrm{Au}-201$ & $2.28 \mathrm{E}-17$ & $\mathrm{Ca}-41$ & $1.15 \mathrm{E}-15$ \\
\hline Ag-104m & 5.32E-17 & Ba-126 & $3.12 \mathrm{E}-16$ & $\mathrm{Ca}-45$ & $5.64 \mathrm{E}-15$ \\
\hline Ag-105 & $3.97 \mathrm{E}-15$ & Ba-128 & $2.58 \mathrm{E}-15$ & $\mathrm{Ca}-47$ & $5.57 \mathrm{E}-15$ \\
\hline Ag-106 & $2.81 \mathrm{E}-17$ & Ba-131 & $5.70 \mathrm{E}-16$ & Cd-104 & $6.42 \mathrm{E}-17$ \\
\hline Ag-106m & $6.08 \mathrm{E}-15$ & Ba-131m & $3.94 \mathrm{E}-18$ & Cd-107 & $9.26 \mathrm{E}-17$ \\
\hline $\mathrm{Ag}-108 \mathrm{~m}$ & $2.56 \mathrm{E}-14$ & Ba-133 & $6.64 \mathrm{E}-15$ & Cd-107 & $9.26 \mathrm{E}-17$ \\
\hline Ag-110m & $6.83 \mathrm{E}-14$ & Ba-133m & $5.29 \mathrm{E}-16$ & Cd-109 & $9.73 \mathrm{E}-14$ \\
\hline Ag-111 & $5.23 \mathrm{E}-15$ & Ba-135m & $4.28 \mathrm{E}-16$ & Cd-113 & $1.42 \mathrm{E}-12$ \\
\hline Ag-112 & $5.64 \mathrm{E}-16$ & Ba-139 & $1.46 \mathrm{E}-16$ & Cd-113m & $1.30 \mathrm{E}-12$ \\
\hline Ag-115 & $5.60 \mathrm{E}-17$ & Ba-140 & $3.18 \mathrm{E}-15$ & Cd-115 & $3.59 \mathrm{E}-15$ \\
\hline Al-26 & $6.77 \mathrm{E}-14$ & Ba-141 & $6.86 \mathrm{E}-17$ & Cd-115m & $6.14 \mathrm{E}-14$ \\
\hline Am-237 & 2.04E-17 & Ba-142 & $3.50 \mathrm{E}-17$ & Cd-117 & $3.84 \mathrm{E}-16$ \\
\hline Am-238 & $7.30 \mathrm{E}-16$ & Be-10 & $3.02 \mathrm{E}-13$ & Cd-117m & $3.72 \mathrm{E}-16$ \\
\hline Am-239 & $3.90 \mathrm{E}-16$ & $\mathrm{Be}-7$ & $2.73 \mathrm{E}-16$ & $\mathrm{Ce}-134$ & $6.96 \mathrm{E}-15$ \\
\hline Am-240 & $1.56 \mathrm{E}-15$ & Bi-200 & $5.60 \mathrm{E}-17$ & $\mathrm{Ce}-135$ & $1.35 \mathrm{E}-15$ \\
\hline Am-241 & $4.44 \mathrm{E}-10$ & Bi-201 & $1.63 \mathrm{E}-16$ & $\mathrm{Ce}-137$ & $3.56 \mathrm{E}-17$ \\
\hline Am-242 & $4.97 \mathrm{E}-14$ & Bi-202 & $1.08 \mathrm{E}-16$ & $\mathrm{Ce}-137 \mathrm{~m}$ & $1.20 \mathrm{E}-15$ \\
\hline Am-242m & $4.35 \mathrm{E}-10$ & Bi-203 & $7.05 \mathrm{E}-16$ & Ce-139 & $7.71 \mathrm{E}-15$ \\
\hline Am-243 & 4.44E-10 & Bi-205 & $3.68 \mathrm{E}-15$ & Ce-141 & 7.62E-15 \\
\hline Am-244 & $1.41 \mathrm{E}-14$ & Bi-206 & $5.57 \mathrm{E}-15$ & $\mathrm{Ce}-143$ & $2.88 \mathrm{E}-15$ \\
\hline Am-244m & $5.98 \mathrm{E}-16$ & Bi-207 & $1.70 \mathrm{E}-14$ & $\mathrm{Ce}-144$ & $3.18 \mathrm{E}-13$ \\
\hline Am-245 & $6.86 \mathrm{E}-17$ & Bi-210 & $1.67 \mathrm{E}-13$ & Cf-244 & $8.44 \mathrm{E}-15$ \\
\hline Am-246 & $5.38 \mathrm{E}-17$ & $\mathrm{Bi}-210 \mathrm{~m}$ & $6.45 \mathrm{E}-12$ & Cf-246 & $5.10 \mathrm{E}-13$ \\
\hline Am-246m & $2.84 \mathrm{E}-17$ & Bi-212 & $1.84 \mathrm{E}-14$ & Cf-248 & $4.31 \mathrm{E}-11$ \\
\hline As-69 & $4.16 \mathrm{E}-17$ & Bi-213 & $1.46 \mathrm{E}-14$ & Cf-249 & $4.91 \mathrm{E}-10$ \\
\hline As-70 & $1.08 \mathrm{E}-16$ & Bi-214 & $5.60 \mathrm{E}-15$ & Cf- 250 & $2.23 \mathrm{E}-10$ \\
\hline As-71 & $1.08 \mathrm{E}-15$ & Bk-245 & $3.75 \mathrm{E}-15$ & Cf-251 & $5.01 \mathrm{E}-10$ \\
\hline As-72 & $3.46 \mathrm{E}-15$ & Bk-246 & $1.46 \mathrm{E}-15$ & Cf-252 & $1.17 \mathrm{E}-10$ \\
\hline As-73 & $2.94 \mathrm{E}-15$ & Bk-247 & $4.88 \mathrm{E}-10$ & Cf-253 & $2.65 \mathrm{E}-12$ \\
\hline As-74 & $6.77 \mathrm{E}-15$ & Bk-249 & $1.18 \mathrm{E}-12$ & Cf-254 & $2.50 \mathrm{E}-10$ \\
\hline As-76 & $3.18 \mathrm{E}-15$ & Bk-250 & $6.42 \mathrm{E}-15$ & Cl-36 & $1.87 \mathrm{E}-14$ \\
\hline As-77 & $8.97 \mathrm{E}-16$ & $\mathrm{Br}-74$ & 7.34E-17 & Cl-38 & $1.14 \mathrm{E}-16$ \\
\hline As-78 & $2.27 \mathrm{E}-16$ & $\mathrm{Br}-74 \mathrm{~m}$ & $1.39 \mathrm{E}-16$ & $\mathrm{Cl}-39$ & $9.63 \mathrm{E}-17$ \\
\hline At-207 & $2.06 \mathrm{E}-15$ & $\mathrm{Br}-75$ & $1.11 \mathrm{E}-16$ & $\mathrm{Cm}-238$ & $4.53 \mathrm{E}-15$ \\
\hline At-211 & 8.69E-14 & $\mathrm{Br}-76$ & $1.36 \mathrm{E}-15$ & $\mathrm{Cm}-240$ & $6.83 \mathrm{E}-12$ \\
\hline $\mathrm{Au}-193$ & $2.46 \mathrm{E}-16$ & Br-77 & $2.35 \mathrm{E}-16$ & $\mathrm{Cm}-241$ & $1.25 \mathrm{E}-13$ \\
\hline
\end{tabular}




\begin{tabular}{|c|c|c|c|c|c|}
\hline \multicolumn{2}{|c|}{$\begin{array}{l}\text { Nuclide CONVERSION } \\
\text { FACTORS ---- PE-g / Bq }\end{array}$} & \multicolumn{2}{|c|}{$\begin{array}{l}\text { Nuclide CONVERSION } \\
\text { FACTORS ---- PE-g / Bq }\end{array}$} & \multicolumn{2}{|c|}{$\begin{array}{l}\text { Nuclide CONVERSION } \\
\text { FACTORS ---- PE-g / Bq }\end{array}$} \\
\hline $\mathrm{Cm}-242$ & $1.47 \mathrm{E}-11$ & Es-254 & $3.50 \mathrm{E}-11$ & Ge-77 & $8.97 \mathrm{E}-16$ \\
\hline $\mathrm{Cm}-243$ & $2.61 \mathrm{E}-10$ & Es-254m & $4.75 \mathrm{E}-13$ & Ge-78 & $2.44 \mathrm{E}-16$ \\
\hline $\mathrm{Cm}-244$ & $2.11 \mathrm{E}-10$ & Eu-145 & $2.33 \mathrm{E}-15$ & H-3 & $5.45 \mathrm{E}-17$ \\
\hline $\mathrm{Cm}-245$ & $4.60 \mathrm{E}-10$ & Eu-146 & $3.31 \mathrm{E}-15$ & Hf-170 & $1.02 \mathrm{E}-15$ \\
\hline $\mathrm{Cm}-246$ & $3.84 \mathrm{E}-10$ & Eu-147 & $3.01 \mathrm{E}-15$ & Hf-172 & $2.71 \mathrm{E}-13$ \\
\hline $\mathrm{Cm}-247$ & $3.53 \mathrm{E}-10$ & Eu-148 & $1.22 \mathrm{E}-14$ & Hf-173 & $4.06 \mathrm{E}-16$ \\
\hline $\mathrm{Cm}-248$ & $1.41 \mathrm{E}-09$ & Eu-149 & $1.61 \mathrm{E}-15$ & Hf-175 & $4.75 \mathrm{E}-15$ \\
\hline $\mathrm{Cm}-249$ & $1.64 \mathrm{E}-16$ & $\mathrm{Eu}-150 \mathrm{hr}$ & $5.73 \mathrm{E}-16$ & Hf- $177 \mathrm{~m}$ & $8.41 \mathrm{E}-17$ \\
\hline Co-55 & $1.78 \mathrm{E}-15$ & Eu-150 yr & $2.28 \mathrm{E}-13$ & Hf-178m & $2.09 \mathrm{E}-12$ \\
\hline Co-56 & $3.37 \mathrm{E}-14$ & Eu-152 & $1.88 \mathrm{E}-13$ & Hf-179m & $8.60 \mathrm{E}-15$ \\
\hline Co-57 & 7.71E-15 & Eu-152m & $6.96 \mathrm{E}-16$ & Hf-180m & $1.98 \mathrm{E}-16$ \\
\hline Co-58 & $9.26 \mathrm{E}-15$ & Eu-154 & $2.43 \mathrm{E}-13$ & Hf-181 & $1.31 \mathrm{E}-14$ \\
\hline Co- $58 \mathrm{~m}$ & $8.00 \mathrm{E}-17$ & Eu-155 & $3.53 \mathrm{E}-14$ & Hf-182 & $2.83 \mathrm{E}-12$ \\
\hline Co-60 & $1.86 \mathrm{E}-13$ & Eu-156 & $1.20 \mathrm{E}-14$ & Hf- $182 \mathrm{~m}$ & $5.29 \mathrm{E}-17$ \\
\hline Co-60m & $1.81 \mathrm{E}-18$ & Eu-157 & $9.48 \mathrm{E}-16$ & Hf-183 & $9.95 \mathrm{E}-17$ \\
\hline Co-61 & $9.01 \mathrm{E}-17$ & Eu-158 & $8.00 \mathrm{E}-17$ & Hf-184 & 7.27E-16 \\
\hline $\mathrm{Co}-62 \mathrm{~m}$ & $2.87 \mathrm{E}-17$ & F-18 & $7.12 \mathrm{E}-17$ & $\mathrm{Hg}-193$ & $1.58 \mathrm{E}-16$ \\
\hline $\mathrm{Cr}-48$ & $7.46 \mathrm{E}-16$ & $\mathrm{Fe}-52$ & $1.86 \mathrm{E}-15$ & Hg-193m & $6.55 \mathrm{E}-16$ \\
\hline $\mathrm{Cr}-49$ & $6.17 \mathrm{E}-17$ & $\mathrm{Fe}-55$ & $2.29 \mathrm{E}-15$ & Hg-194 & $1.54 \mathrm{E}-13$ \\
\hline Cr-51 & $2.84 \mathrm{E}-16$ & $\mathrm{Fe}-59$ & $1.26 \mathrm{E}-14$ & $\mathrm{Hg}-195$ & $1.76 \mathrm{E}-16$ \\
\hline Cs-125 & $3.53 \mathrm{E}-17$ & Fe-60 & $6.36 \mathrm{E}-13$ & $\mathrm{Hg}-195 \mathrm{~m}$ & $1.30 \mathrm{E}-15$ \\
\hline Cs-127 & $5.01 \mathrm{E}-17$ & Fm-252 & $3.59 \mathrm{E}-13$ & Hg-197 & $6.05 \mathrm{E}-16$ \\
\hline Cs-129 & $1.35 \mathrm{E}-16$ & Fm-253 & $4.91 \mathrm{E}-13$ & $\mathrm{Hg}-197 \mathrm{~m}$ & $1.02 \mathrm{E}-15$ \\
\hline Cs-130 & $2.54 \mathrm{E}-17$ & Fm-254 & 4.94E-14 & $\mathrm{Hg}-199 \mathrm{~m}$ & $5.73 \mathrm{E}-17$ \\
\hline Cs-131 & $1.42 \mathrm{E}-16$ & Fm-255 & $2.27 \mathrm{E}-13$ & $\mathrm{Hg}-203$ & $6.23 \mathrm{E}-15$ \\
\hline Cs-132 & $1.05 \mathrm{E}-15$ & Fm-257 & $1.99 \mathrm{E}-11$ & Нo-155 & $3.81 \mathrm{E}-17$ \\
\hline Cs-134 & $4.00 \mathrm{E}-14$ & Fr-222 & $1.05 \mathrm{E}-14$ & Ho-157 & $4.44 \mathrm{E}-18$ \\
\hline Cs-134m & $3.72 \mathrm{E}-17$ & Fr-223 & 5.29E-15 & Ho-159 & $5.54 \mathrm{E}-18$ \\
\hline Cs-135 & $3.87 \mathrm{E}-15$ & Ga-65 & $2.86 \mathrm{E}-17$ & Ho-161 & $1.32 \mathrm{E}-17$ \\
\hline Cs- $135 \mathrm{~m}$ & $2.10 \mathrm{E}-17$ & Ga-66 & $1.58 \mathrm{E}-15$ & Но-162 & $2.00 \mathrm{E}-18$ \\
\hline Cs-136 & $6.23 \mathrm{E}-15$ & Ga-67 & $4.75 \mathrm{E}-16$ & Но- $162 \mathrm{~m}$ & $2.14 \mathrm{E}-17$ \\
\hline Cs-137 & $2.72 \mathrm{E}-14$ & Ga-68 & $1.18 \mathrm{E}-16$ & Но-164 & $7.40 \mathrm{E}-18$ \\
\hline Cs-138 & $8.63 \mathrm{E}-17$ & Ga-70 & $2.68 \mathrm{E}-17$ & Нo- $164 \mathrm{~m}$ & $1.62 \mathrm{E}-17$ \\
\hline $\mathrm{Cu}-60$ & 5.89E-17 & Ga-72 & $1.58 \mathrm{E}-15$ & Но-166 & $2.67 \mathrm{E}-15$ \\
\hline $\mathrm{Cu}-61$ & $1.59 \mathrm{E}-16$ & Ga-73 & $3.24 \mathrm{E}-16$ & Нo-166m & $6.58 \mathrm{E}-13$ \\
\hline $\mathrm{Cu}-64$ & $2.36 \mathrm{E}-16$ & Gd-145 & $3.84 \mathrm{E}-17$ & Но-167 & $9.26 \mathrm{E}-17$ \\
\hline $\mathrm{Cu}-67$ & $1.05 \mathrm{E}-15$ & Gd-146 & $3.24 \mathrm{E}-14$ & I-120 & $3.78 \mathrm{E}-16$ \\
\hline Dy-155 & $1.89 \mathrm{E}-16$ & Gd-147 & $1.53 \mathrm{E}-15$ & $\mathrm{I}-120 \mathrm{~m}$ & $2.25 \mathrm{E}-16$ \\
\hline Dy-157 & $6.80 \mathrm{E}-17$ & Gd-148 & $2.81 \mathrm{E}-10$ & $\mathrm{I}-121$ & $1.01 \mathrm{E}-16$ \\
\hline Dy-159 & $2.07 \mathrm{E}-15$ & Gd-149 & $1.95 \mathrm{E}-15$ & $\mathrm{I}-123$ & $2.52 \mathrm{E}-16$ \\
\hline Dy-165 & $1.14 \mathrm{E}-16$ & Gd-151 & $7.56 \mathrm{E}-15$ & I-124 & $1.65 \mathrm{E}-14$ \\
\hline Dy-166 & $6.36 \mathrm{E}-15$ & Gd-152 & $2.07 \mathrm{E}-10$ & I-125 & $2.06 \mathrm{E}-14$ \\
\hline Er-161 & $7.71 \mathrm{E}-17$ & Gd-153 & $2.02 \mathrm{E}-14$ & I-126 & $3.78 \mathrm{E}-14$ \\
\hline Er-165 & $2.54 \mathrm{E}-17$ & Gd-159 & $8.31 \mathrm{E}-16$ & I-128 & $4.03 \mathrm{E}-17$ \\
\hline Er-169 & $1.78 \mathrm{E}-15$ & Ge-66 & $2.70 \mathrm{E}-16$ & I-129 & $1.48 \mathrm{E}-13$ \\
\hline Er-171 & $4.79 \mathrm{E}-16$ & Ge-67 & $5.16 \mathrm{E}-17$ & I-130 & $2.25 \mathrm{E}-15$ \\
\hline Er-172 & $3.50 \mathrm{E}-15$ & Ge-68 & $4.41 \mathrm{E}-14$ & I-131 & $2.80 \mathrm{E}-14$ \\
\hline Es-250 & $4.09 \mathrm{E}-15$ & Ge-69 & $7.15 \mathrm{E}-16$ & I-132 & $3.24 \mathrm{E}-16$ \\
\hline Es-251 & $4.03 \mathrm{E}-15$ & Ge-71 & $1.04 \mathrm{E}-16$ & $\mathrm{I}-132 \mathrm{~m}$ & $2.55 \mathrm{E}-16$ \\
\hline Es-253 & $3.37 \mathrm{E}-12$ & $\mathrm{Ge}-75$ & $6.05 \mathrm{E}-17$ & I-133 & $4.97 \mathrm{E}-15$ \\
\hline
\end{tabular}




\begin{tabular}{|c|c|}
\hline \multicolumn{2}{|c|}{$\begin{array}{l}\text { Nuclide CONVERSION } \\
\text { FACTORS --- PE-g / Bq }\end{array}$} \\
\hline I-134 & $1.12 \mathrm{E}-16$ \\
\hline $\mathrm{I}-135$ & $1.05 \mathrm{E}-15$ \\
\hline In-109 & $1.01 \mathrm{E}-16$ \\
\hline In-110 hr & $1.15 \mathrm{E}-16$ \\
\hline In-110 min & $2.62 \mathrm{E}-16$ \\
\hline In-111 & $7.15 \mathrm{E}-16$ \\
\hline In-112 & $7.68 \mathrm{E}-18$ \\
\hline In-113m & $3.50 \mathrm{E}-17$ \\
\hline In-114m & $7.56 \mathrm{E}-14$ \\
\hline In-115 & $3.18 \mathrm{E}-12$ \\
\hline In-115m & $1.13 \mathrm{E}-16$ \\
\hline In-116m & $6.49 \mathrm{E}-17$ \\
\hline In-117 & $3.13 \mathrm{E}-17$ \\
\hline In-117m & $1.51 \mathrm{E}-16$ \\
\hline In-119m & $3.78 \mathrm{E}-17$ \\
\hline Ir-182 & $4.12 \mathrm{E}-17$ \\
\hline Ir-184 & $1.96 \mathrm{E}-16$ \\
\hline Ir-185 & $4.66 \mathrm{E}-16$ \\
\hline Ir-186 & $7.75 \mathrm{E}-16$ \\
\hline Ir-187 & $1.79 \mathrm{E}-16$ \\
\hline Ir-188 & $1.31 \mathrm{E}-15$ \\
\hline Ir-189 & $1.40 \mathrm{E}-15$ \\
\hline Ir-190 & $5.45 \mathrm{E}-15$ \\
\hline Ir-190m & $2.59 \mathrm{E}-17$ \\
\hline Ir-192 & $2.40 \mathrm{E}-14$ \\
\hline Ir-192m & $3.27 \mathrm{E}-13$ \\
\hline Ir-194 & $2.47 \mathrm{E}-15$ \\
\hline Ir-194m & $5.83 \mathrm{E}-14$ \\
\hline Ir-195 & $1.18 \mathrm{E}-16$ \\
\hline Ir-195m & $2.12 \mathrm{E}-16$ \\
\hline $\mathrm{K}-40$ & $1.05 \mathrm{E}-14$ \\
\hline K-42 & $1.16 \mathrm{E}-15$ \\
\hline K-43 & $5.89 \mathrm{E}-16$ \\
\hline K-44 & $7.05 \mathrm{E}-17$ \\
\hline $\mathrm{K}-45$ & $4.38 \mathrm{E}-17$ \\
\hline $\mathrm{Kr}-85$ & $1.1 \mathrm{E}-14$ \\
\hline La-131 & $4.41 \mathrm{E}-17$ \\
\hline La-132 & $4.66 \mathrm{E}-16$ \\
\hline La-135 & $5.04 \mathrm{E}-17$ \\
\hline La-137 & $7.46 \mathrm{E}-10$ \\
\hline La-138 & $1.17 \mathrm{E}-12$ \\
\hline La-140 & $4.12 \mathrm{E}-15$ \\
\hline La-141 & $4.94 \mathrm{E}-16$ \\
\hline La-142 & $2.15 \mathrm{E}-16$ \\
\hline La-143 & $5.10 \mathrm{E}-17$ \\
\hline Lu-169 & $1.15 \mathrm{E}-15$ \\
\hline Lu-170 & $2.19 \mathrm{E}-15$ \\
\hline Lu-171 & $2.54 \mathrm{E}-15$ \\
\hline Lu-172 & $4.25 \mathrm{E}-15$ \\
\hline Lu-173 & $1.92 \mathrm{E}-14$ \\
\hline
\end{tabular}

\begin{tabular}{|c|c|}
\hline \multicolumn{2}{|c|}{$\begin{array}{l}\text { Nuclide CONVERSION } \\
\text { FACTORS ---- PE-g / Bq }\end{array}$} \\
\hline Lu-174 & $3.37 \mathrm{E}-14$ \\
\hline Lu-174m & $2.16 \mathrm{E}-14$ \\
\hline Lu-176 & $5.64 \mathrm{E}-13$ \\
\hline Lu-176m & $2.27 \mathrm{E}-16$ \\
\hline Lu-177 & $2.09 \mathrm{E}-15$ \\
\hline Lu-177m & $6.11 \mathrm{E}-14$ \\
\hline Lu-178 & $3.97 \mathrm{E}-17$ \\
\hline Lu-178m & $2.78 \mathrm{E}-17$ \\
\hline Lu-179 & $2.87 \mathrm{E}-16$ \\
\hline Md-257 & $4.88 \mathrm{E}-14$ \\
\hline Md-258 & $1.41 \mathrm{E}-11$ \\
\hline $\mathrm{Mg}-28$ & 4.19E-15 \\
\hline $\mathrm{Mn}-51$ & $9.76 \mathrm{E}-17$ \\
\hline $\mathrm{Mn}-52$ & $4.85 \mathrm{E}-15$ \\
\hline $\mathrm{Mn}-52 \mathrm{~m}$ & $5.76 \mathrm{E}-17$ \\
\hline $\mathrm{Mn}-53$ & $4.25 \mathrm{E}-16$ \\
\hline $\mathrm{Mn}-54$ & $5.70 \mathrm{E}-15$ \\
\hline $\mathrm{Mn}-56$ & $3.21 \mathrm{E}-16$ \\
\hline Mo-101 & $3.53 \mathrm{E}-17$ \\
\hline Mo-90 & $1.05 \mathrm{E}-15$ \\
\hline Mo-93 & $2.42 \mathrm{E}-14$ \\
\hline Mo-93m & $3.27 \mathrm{E}-16$ \\
\hline Mo-99 & $3.37 \mathrm{E}-15$ \\
\hline $\mathrm{Na}-22$ & $6.80 \mathrm{E}-15$ \\
\hline $\mathrm{Na}-24$ & $1.03 \mathrm{E}-15$ \\
\hline $\mathrm{Nb}-88$ & $2.29 \mathrm{E}-17$ \\
\hline $\mathrm{Nb}-89(122)$ & $3.50 \mathrm{E}-16$ \\
\hline $\mathrm{Nb}-89(66)$ & $1.52 \mathrm{E}-16$ \\
\hline $\mathrm{Nb}-90$ & $1.95 \mathrm{E}-15$ \\
\hline $\mathrm{Nb}-93 \mathrm{~m}$ & $2.51 \mathrm{E}-14$ \\
\hline $\mathrm{Nb}-94$ & $3.53 \mathrm{E}-13$ \\
\hline $\mathrm{Nb}-95$ & $4.94 \mathrm{E}-15$ \\
\hline $\mathrm{Nb}-95 \mathrm{~m}$ & $2.07 \mathrm{E}-15$ \\
\hline $\mathrm{Nb}-96$ & $1.95 \mathrm{E}-15$ \\
\hline $\mathrm{Nb}-97$ & $7.05 \mathrm{E}-17$ \\
\hline $\mathrm{Nb}-98$ & $1.04 \mathrm{E}-16$ \\
\hline $\mathrm{Nd}-136$ & $9.82 \mathrm{E}-17$ \\
\hline Nd-138 & $8.75 \mathrm{E}-16$ \\
\hline Nd-139 & $1.80 \mathrm{E}-17$ \\
\hline $\mathrm{Nd}-139 \mathrm{~m}$ & $3.18 \mathrm{E}-16$ \\
\hline Nd-141 & $8.75 \mathrm{E}-18$ \\
\hline $\mathrm{Nd}-147$ & $5.83 \mathrm{E}-15$ \\
\hline $\mathrm{Nd}-149$ & $1.90 \mathrm{E}-16$ \\
\hline $\mathrm{Nd}-151$ & $2.65 \mathrm{E}-17$ \\
\hline $\mathrm{Ni}-56$ & $3.53 \mathrm{E}-15$ \\
\hline $\mathrm{Ni}-57$ & $1.61 \mathrm{E}-15$ \\
\hline $\mathrm{Ni}-59$ & $2.30 \mathrm{E}-15$ \\
\hline $\mathrm{Ni}-63$ & $5.35 \mathrm{E}-15$ \\
\hline $\mathrm{Ni}-65$ & $2.93 \mathrm{E}-16$ \\
\hline Ni-66 & $7.08 \mathrm{E}-15$ \\
\hline
\end{tabular}

\begin{tabular}{|c|c|}
\hline \multicolumn{2}{|c|}{$\begin{array}{l}\text { Nuclide CONVERSION } \\
\text { FACTORS ---- PE-g / Bq }\end{array}$} \\
\hline $\mathrm{Np}-232$ & $1.07 \mathrm{E}-15$ \\
\hline $\mathrm{Np}-233$ & $1.85 \mathrm{E}-18$ \\
\hline $\mathrm{Np}-234$ & $1.73 \mathrm{E}-15$ \\
\hline $\mathrm{Np}-235$ & $3.53 \mathrm{E}-15$ \\
\hline $\mathrm{Np}-236 \mathrm{hr}$ & $7.02 \mathrm{E}-14$ \\
\hline $\mathrm{Np}-236 \mathrm{yr}$ & $8.85 \mathrm{E}-11$ \\
\hline $\mathrm{Np}-237$ & $4.60 \mathrm{E}-10$ \\
\hline $\mathrm{Np}-238$ & $3.15 \mathrm{E}-14$ \\
\hline $\mathrm{Np}-239$ & $2.13 \mathrm{E}-15$ \\
\hline $\mathrm{Np}-240$ & $6.93 \mathrm{E}-17$ \\
\hline Os-180 & $1.48 \mathrm{E}-17$ \\
\hline Os-181 & $1.14 \mathrm{E}-16$ \\
\hline Os-182 & $1.17 \mathrm{E}-15$ \\
\hline Os-185 & $8.82 \mathrm{E}-15$ \\
\hline Os-189m & $2.54 \mathrm{E}-17$ \\
\hline Os-191 & $3.56 \mathrm{E}-15$ \\
\hline Os-191m & $2.58 \mathrm{E}-16$ \\
\hline Os-193 & $1.70 \mathrm{E}-15$ \\
\hline Os-194 & $5.70 \mathrm{E}-13$ \\
\hline P-32 & $1.32 \mathrm{E}-14$ \\
\hline P-33 & $1.97 \mathrm{E}-15$ \\
\hline $\mathrm{Pa}-227$ & $4.16 \mathrm{E}-14$ \\
\hline $\mathrm{Pa}-228$ & $3.75 \mathrm{E}-13$ \\
\hline $\mathrm{Pa}-230$ & $1.25 \mathrm{E}-12$ \\
\hline $\mathrm{Pa}-231$ & $1.09 \mathrm{E}-09$ \\
\hline $\mathrm{Pa}-232$ & $7.78 \mathrm{E}-14$ \\
\hline $\mathrm{Pa}-233$ & $8.12 \mathrm{E}-15$ \\
\hline $\mathrm{Pa}-234$ & $6.93 \mathrm{E}-16$ \\
\hline $\mathrm{Pb}-195 \mathrm{~m}$ & $2.64 \mathrm{E}-17$ \\
\hline $\mathrm{Pb}-198$ & $6.55 \mathrm{E}-17$ \\
\hline Pb-199 & $6.20 \mathrm{E}-17$ \\
\hline $\mathrm{Pb}-200$ & $6.74 \mathrm{E}-16$ \\
\hline $\mathrm{Pb}-201$ & $2.23 \mathrm{E}-16$ \\
\hline $\mathrm{Pb}-202$ & $8.34 \mathrm{E}-14$ \\
\hline $\mathrm{Pb}-202 \mathrm{~m}$ & $1.52 \mathrm{E}-16$ \\
\hline $\mathrm{Pb}-203$ & $4.50 \mathrm{E}-16$ \\
\hline $\mathrm{Pb}-205$ & $3.34 \mathrm{E}-15$ \\
\hline $\mathrm{Pb}-205$ & $3.34 \mathrm{E}-15$ \\
\hline Pb-209 & $8.06 \mathrm{E}-17$ \\
\hline $\mathrm{Pb}-210$ & $1.16 \mathrm{E}-11$ \\
\hline $\mathrm{Pb}-211$ & $7.40 \mathrm{E}-15$ \\
\hline $\mathrm{Pb}-212$ & $1.44 \mathrm{E}-13$ \\
\hline $\mathrm{Pb}-214$ & $6.64 \mathrm{E}-15$ \\
\hline Pd-100 & $3.34 \mathrm{E}-15$ \\
\hline Pd-101 & $1.58 \mathrm{E}-16$ \\
\hline Pd-103 & $1.34 \mathrm{E}-15$ \\
\hline Pd-107 & $1.09 \mathrm{E}-14$ \\
\hline Pd-109 & $9.32 \mathrm{E}-16$ \\
\hline Pm-141 & $2.70 \mathrm{E}-17$ \\
\hline Pm-143 & $9.26 \mathrm{E}-15$ \\
\hline
\end{tabular}




\begin{tabular}{|c|c|}
\hline \multicolumn{2}{|c|}{$\begin{array}{l}\text { Nuclide CONVERSION } \\
\text { FACTORS ---- PE-g / Bq }\end{array}$} \\
\hline Pm-144 & $4.57 \mathrm{E}-14$ \\
\hline Pm-145 & $2.59 \mathrm{E}-14$ \\
\hline Pm-146 & $1.25 \mathrm{E}-13$ \\
\hline Pm-147 & $3.34 \mathrm{E}-14$ \\
\hline Pm-148 & $9.29 \mathrm{E}-15$ \\
\hline $\mathrm{Pm}-148 \mathrm{~m}$ & $1.92 \mathrm{E}-14$ \\
\hline Pm-149 & $2.50 \mathrm{E}-15$ \\
\hline Pm-150 & $3.08 \mathrm{E}-16$ \\
\hline Pm-151 & $1.49 \mathrm{E}-15$ \\
\hline Po-203 & $6.74 \mathrm{E}-17$ \\
\hline Po-205 & $1.15 \mathrm{E}-16$ \\
\hline Po-207 & $1.72 \mathrm{E}-16$ \\
\hline Po-210 & $8.00 \mathrm{E}-12$ \\
\hline Pr-136 & $2.10 \mathrm{E}-17$ \\
\hline Pr-137 & $4.06 \mathrm{E}-17$ \\
\hline $\operatorname{Pr}-138 \mathrm{~m}$ & $1.15 \mathrm{E}-16$ \\
\hline $\operatorname{Pr}-139$ & $4.91 \mathrm{E}-17$ \\
\hline Pr-142 & $2.45 \mathrm{E}-15$ \\
\hline Pr-142m & $3.14 \mathrm{E}-17$ \\
\hline Pr-143 & $6.90 \mathrm{E}-15$ \\
\hline Pr-144 & $3.68 \mathrm{E}-17$ \\
\hline Pr-145 & $5.73 \mathrm{E}-16$ \\
\hline Pr-147 & $2.59 \mathrm{E}-17$ \\
\hline Pt-186 & $1.13 \mathrm{E}-16$ \\
\hline Pt-188 & $2.67 \mathrm{E}-15$ \\
\hline Pt-189 & $1.52 \mathrm{E}-16$ \\
\hline Pt-191 & $5.23 \mathrm{E}-16$ \\
\hline Pt-193 & $1.93 \mathrm{E}-16$ \\
\hline Pt-193m & $7.46 \mathrm{E}-16$ \\
\hline Pt-195m & $1.04 \mathrm{E}-15$ \\
\hline Pt-197 & $4.82 \mathrm{E}-16$ \\
\hline Pt-197m & $1.04 \mathrm{E}-16$ \\
\hline Pt-199 & $3.87 \mathrm{E}-17$ \\
\hline Pt-200 & $1.42 \mathrm{E}-15$ \\
\hline $\mathrm{Pu}-234$ & $2.33 \mathrm{E}-14$ \\
\hline $\mathrm{Pu}-235$ & $1.94 \mathrm{E}-18$ \\
\hline $\mathrm{Pu}-236$ & $1.23 \mathrm{E}-10$ \\
\hline $\mathrm{Pu}-237$ & $1.68 \mathrm{E}-15$ \\
\hline $\mathrm{Pu}-238$ & $3.90 \mathrm{E}-10$ \\
\hline $\mathrm{Pu}-239$ & $4.35 \mathrm{E}-10$ \\
\hline $\mathrm{Pu}-240$ & $4.35 \mathrm{E}-10$ \\
\hline $\mathrm{Pu}-241$ & $8.50 \mathrm{E}-12$ \\
\hline $\mathrm{Pu}-242$ & $4.09 \mathrm{E}-10$ \\
\hline $\mathrm{Pu}-243$ & $1.40 \mathrm{E}-16$ \\
\hline $\mathrm{Pu}-244$ & $3.43 \mathrm{E}-10$ \\
\hline $\mathrm{Pu}-245$ & $1.12 \mathrm{E}-15$ \\
\hline Ra-223 & $6.68 \mathrm{E}-12$ \\
\hline Ra-224 & $2.69 \mathrm{E}-12$ \\
\hline Ra-225 & $6.61 \mathrm{E}-12$ \\
\hline
\end{tabular}

\begin{tabular}{|c|c|}
\hline \multicolumn{2}{|c|}{$\begin{array}{l}\text { Nuclide CONVERSION } \\
\text { FACTORS ---- PE-g / Bq }\end{array}$} \\
\hline Ra-226 & $7.30 \mathrm{E}-12$ \\
\hline $\mathrm{Ra}-227$ & $2.42 \mathrm{E}-16$ \\
\hline $\mathrm{Ra}-228$ & $4.06 \mathrm{E}-12$ \\
\hline $\mathrm{Rb}-79$ & 4.19E-17 \\
\hline $\mathrm{Rb}-81$ & $1.11 \mathrm{E}-16$ \\
\hline $\mathrm{Rb}-81 \mathrm{~m}$ & $1.71 \mathrm{E}-17$ \\
\hline $\mathrm{Rb}-82 \mathrm{~m}$ & $2.47 \mathrm{E}-16$ \\
\hline $\mathrm{Rb}-83$ & 4.19E-15 \\
\hline $\mathrm{Rb}-84$ & $5.54 \mathrm{E}-15$ \\
\hline $\mathrm{Rb}-86$ & $5.64 \mathrm{E}-15$ \\
\hline $\mathrm{Rb}-87$ & $2.75 \mathrm{E}-15$ \\
\hline $\mathrm{Rb}-88$ & $7.12 \mathrm{E}-17$ \\
\hline $\mathrm{Rb}-89$ & $3.65 \mathrm{E}-17$ \\
\hline Re-177 & $2.03 \mathrm{E}-17$ \\
\hline Re-178 & $1.92 \mathrm{E}-17$ \\
\hline Re-181 & $5.48 \mathrm{E}-16$ \\
\hline Re-182(12.7) & $3.43 \mathrm{E}-16$ \\
\hline Re-182(64) & $2.43 \mathrm{E}-15$ \\
\hline Re-184 & $4.38 \mathrm{E}-15$ \\
\hline Re-184m & $1.25 \mathrm{E}-14$ \\
\hline Re-186 & $2.72 \mathrm{E}-15$ \\
\hline Re-186m & $3.07 \mathrm{E}-14$ \\
\hline Re-187 & $4.63 \mathrm{E}-17$ \\
\hline Re-188 & $1.71 \mathrm{E}-15$ \\
\hline Re-188m & $3.50 \mathrm{E}-17$ \\
\hline Re-189 & $1.06 \mathrm{E}-15$ \\
\hline Rh-99 & $2.63 \mathrm{E}-15$ \\
\hline Rh-99m & 7.37E-17 \\
\hline Rh-100 & $1.18 \mathrm{E}-15$ \\
\hline Rh-101 & $8.66 \mathrm{E}-15$ \\
\hline Rh-101m & $6.36 \mathrm{E}-16$ \\
\hline Rh-102 & $1.02 \mathrm{E}-13$ \\
\hline Rh-102m & $4.06 \mathrm{E}-14$ \\
\hline Rh-103m & $4.35 \mathrm{E}-18$ \\
\hline Rh-105 & $8.12 \mathrm{E}-16$ \\
\hline Rh-106m & $1.82 \mathrm{E}-16$ \\
\hline Rh-107 & $2.06 \mathrm{E}-17$ \\
\hline Rn-220 & $3.15 \mathrm{E}-14$ \\
\hline Rn-222 & $8.82 \mathrm{E}-13$ \\
\hline Ru-94 & $1.13 \mathrm{E}-16$ \\
\hline Ru-97 & $3.84 \mathrm{E}-16$ \\
\hline Ru-103 & $7.62 \mathrm{E}-15$ \\
\hline Ru-105 & $3.87 \mathrm{E}-16$ \\
\hline Ru-106 & $4.06 \mathrm{E}-13$ \\
\hline S-35 & $1.11 \mathrm{E}-14$ \\
\hline Sb-115 & $2.22 \mathrm{E}-17$ \\
\hline Sb-116 & $1.97 \mathrm{E}-17$ \\
\hline Sb-116m & $6.52 \mathrm{E}-17$ \\
\hline Sb-117 & $2.13 \mathrm{E}-17$ \\
\hline
\end{tabular}

\begin{tabular}{|c|c|}
\hline \multicolumn{2}{|c|}{$\begin{array}{l}\text { Nuclide CONVERSION } \\
\text { FACTORS ---- PE-g / Bq }\end{array}$} \\
\hline $\mathrm{Sb}-118 \mathrm{~m}$ & $2.23 \mathrm{E}-16$ \\
\hline Sb-119 & $1.79 \mathrm{E}-16$ \\
\hline Sb-120 day & $3.46 \mathrm{E}-15$ \\
\hline $\mathrm{Sb}-120 \mathrm{~min}$ & $1.11 \mathrm{E}-17$ \\
\hline $\mathrm{Sb}-122$ & $4.38 \mathrm{E}-15$ \\
\hline Sb-124 & $2.14 \mathrm{E}-14$ \\
\hline $\mathrm{Sb}-124 \mathrm{~m}$ & $8.82 \mathrm{E}-18$ \\
\hline Sb-125 & $1.04 \mathrm{E}-14$ \\
\hline Sb-126 & $9.98 \mathrm{E}-15$ \\
\hline $\mathrm{Sb}-126 \mathrm{~m}$ & $2.89 \mathrm{E}-17$ \\
\hline $\mathrm{Sb}-127$ & $5.13 \mathrm{E}-15$ \\
\hline $\mathrm{Sb}-128 \mathrm{hr}$ & $1.44 \mathrm{E}-15$ \\
\hline Sb-128 min & $1.50 \mathrm{E}-17$ \\
\hline Sb-129 & $5.48 \mathrm{E}-16$ \\
\hline Sb-130 & $8.82 \mathrm{E}-17$ \\
\hline Sb-131 & $1.22 \mathrm{E}-16$ \\
\hline Sc-43 & $2.20 \mathrm{E}-16$ \\
\hline Sc-44 & $4.19 \mathrm{E}-16$ \\
\hline Sc- $44 m$ & $6.45 \mathrm{E}-15$ \\
\hline Sc-46 & $2.52 \mathrm{E}-14$ \\
\hline Sc-47 & $1.57 \mathrm{E}-15$ \\
\hline Sc-48 & $3.50 \mathrm{E}-15$ \\
\hline Sc-49 & $8.66 \mathrm{E}-17$ \\
\hline Se-70 & $1.50 \mathrm{E}-16$ \\
\hline Se-73 & $3.90 \mathrm{E}-16$ \\
\hline Se-73m & $3.94 \mathrm{E}-17$ \\
\hline $\mathrm{Se}-75$ & $7.21 \mathrm{E}-15$ \\
\hline Se-79 & $8.38 \mathrm{E}-15$ \\
\hline $\mathrm{Se}-81$ & $2.19 \mathrm{E}-17$ \\
\hline Se- $81 \mathrm{~m}$ & $7.53 \mathrm{E}-17$ \\
\hline $\mathrm{Se}-83$ & $4.66 \mathrm{E}-17$ \\
\hline $\mathrm{Si}-31$ & $1.90 \mathrm{E}-16$ \\
\hline $\mathrm{Si}-32$ & $8.63 \mathrm{E}-13$ \\
\hline Sm-141 & $2.61 \mathrm{E}-17$ \\
\hline Sm-141m & 4.97E-17 \\
\hline Sm-142 & $1.83 \mathrm{E}-16$ \\
\hline Sm-145 & $9.38 \mathrm{E}-15$ \\
\hline Sm-146 & $7.02 \mathrm{E}-11$ \\
\hline Sm-147 & $6.36 \mathrm{E}-11$ \\
\hline Sm-151 & $2.55 \mathrm{E}-14$ \\
\hline Sm-153 & $1.67 \mathrm{E}-15$ \\
\hline Sm-155 & $2.14 \mathrm{E}-17$ \\
\hline Sm-156 & $5.95 \mathrm{E}-16$ \\
\hline Sn-110 & $4.28 \mathrm{E}-16$ \\
\hline Sn-111 & $2.31 \mathrm{E}-17$ \\
\hline Sn-113 & $9.07 \mathrm{E}-15$ \\
\hline Sn-117m & $3.68 \mathrm{E}-15$ \\
\hline $\mathrm{Sn}-119 \mathrm{~m}$ & $5.32 \mathrm{E}-15$ \\
\hline Sn-121 & $4.35 \mathrm{E}-16$ \\
\hline
\end{tabular}




\begin{tabular}{|c|c|}
\hline \multicolumn{2}{|c|}{$\begin{array}{l}\text { Nuclide CONVERSION } \\
\text { FACTORS ---- PE-g / Bq }\end{array}$} \\
\hline Sn- $121 \mathrm{~m}$ & $9.79 \mathrm{E}-15$ \\
\hline Sn-123 & $2.77 \mathrm{E}-14$ \\
\hline Sn-123m & $3.94 \mathrm{E}-17$ \\
\hline Sn-125 & $1.32 \mathrm{E}-14$ \\
\hline Sn-126 & $8.47 \mathrm{E}-14$ \\
\hline Sn-127 & $2.76 \mathrm{E}-16$ \\
\hline Sn-128 & $1.84 \mathrm{E}-16$ \\
\hline Sr- 80 & $4.28 \mathrm{E}-16$ \\
\hline Sr-81 & $7.18 \mathrm{E}-17$ \\
\hline Sr-83 & $1.29 \mathrm{E}-15$ \\
\hline Sr- 85 & $4.28 \mathrm{E}-15$ \\
\hline Sr- $85 \mathrm{~m}$ & $7.24 \mathrm{E}-18$ \\
\hline $\mathrm{Sr}-87 \mathrm{~m}$ & $3.65 \mathrm{E}-17$ \\
\hline Sr-89 & $3.53 \mathrm{E}-14$ \\
\hline Sr-90 & $1.11 \mathrm{E}-12$ \\
\hline Sr-91 & $1.41 \mathrm{E}-15$ \\
\hline Sr-92 & $6.86 \mathrm{E}-16$ \\
\hline Ta-172 & $4.82 \mathrm{E}-17$ \\
\hline Ta-173 & $2.72 \mathrm{E}-16$ \\
\hline Ta-174 & $5.73 \mathrm{E}-17$ \\
\hline Ta-175 & $3.24 \mathrm{E}-16$ \\
\hline Ta-176 & $3.97 \mathrm{E}-16$ \\
\hline Ta-177 & $2.61 \mathrm{E}-16$ \\
\hline Ta-178 & $7.05 \mathrm{E}-17$ \\
\hline Ta-179 & $5.54 \mathrm{E}-15$ \\
\hline Ta-180 & $2.08 \mathrm{E}-13$ \\
\hline Ta-180m & 7.93E-17 \\
\hline Ta-182 & $3.81 \mathrm{E}-14$ \\
\hline Ta-182m & $1.14 \mathrm{E}-17$ \\
\hline Ta-183 & $4.44 \mathrm{E}-15$ \\
\hline Ta-184 & $9.73 \mathrm{E}-16$ \\
\hline Ta-185 & $7.15 \mathrm{E}-17$ \\
\hline Ta-186 & $2.07 \mathrm{E}-17$ \\
\hline Tb-147 & $1.77 \mathrm{E}-16$ \\
\hline Tb-149 & $6.23 \mathrm{E}-15$ \\
\hline Tb-150 & $2.65 \mathrm{E}-16$ \\
\hline Tb-151 & $5.32 \mathrm{E}-16$ \\
\hline Tb-153 & $9.26 \mathrm{E}-16$ \\
\hline Tb-154 & $1.01 \mathrm{E}-15$ \\
\hline Tb-155 & $6.61 \mathrm{E}-16$ \\
\hline Tb-156 & $3.34 \mathrm{E}-15$ \\
\hline $\mathrm{Tb}-156 \mathrm{~m}_{(24.4)}$ & $6.49 \mathrm{E}-16$ \\
\hline Tb-156m (5.0) & $1.85 \mathrm{E}-16$ \\
\hline Tb-157 & $7.84 \mathrm{E}-15$ \\
\hline Tb-158 & $2.18 \mathrm{E}-13$ \\
\hline Tb-160 & $2.13 \mathrm{E}-14$ \\
\hline Tb-161 & $2.90 \mathrm{E}-15$ \\
\hline Tc-101 & $1.52 \mathrm{E}-17$ \\
\hline Tc-104 & $6.99 \mathrm{E}-17$ \\
\hline Tc-93 & $6.05 \mathrm{E}-17$ \\
\hline
\end{tabular}

\begin{tabular}{|c|c|}
\hline \multicolumn{2}{|c|}{$\begin{array}{l}\text { Nuclide CONVERSION } \\
\text { FACTORS ---- PE-g / Bq }\end{array}$} \\
\hline Tc-93m & $2.85 \mathrm{E}-17$ \\
\hline Tc-94 & $2.29 \mathrm{E}-16$ \\
\hline Tc-94m & $1.20 \mathrm{E}-16$ \\
\hline Tc-96 & $2.02 \mathrm{E}-15$ \\
\hline Tc-96m & $1.97 \mathrm{E}-17$ \\
\hline Tc-97 & $8.44 \mathrm{E}-16$ \\
\hline Tc-97m & $4.16 \mathrm{E}-15$ \\
\hline Tc-98 & $1.95 \mathrm{E}-14$ \\
\hline Tc-99 & $7.08 \mathrm{E}-15$ \\
\hline Tc-99m & $2.77 \mathrm{E}-17$ \\
\hline Te-116 & $2.26 \mathrm{E}-16$ \\
\hline Te-121 & $1.62 \mathrm{E}-15$ \\
\hline Te-121m & $1.36 \mathrm{E}-14$ \\
\hline Te-123 & $8.97 \mathrm{E}-15$ \\
\hline Te-123m & $9.01 \mathrm{E}-15$ \\
\hline Te-125m & $6.20 \mathrm{E}-15$ \\
\hline Te-127 & $2.71 \mathrm{E}-16$ \\
\hline Te- $127 \mathrm{~m}$ & $1.83 \mathrm{E}-14$ \\
\hline Te-129 & $7.62 \mathrm{E}-17$ \\
\hline Te-129m & $2.04 \mathrm{E}-14$ \\
\hline Te-131 & $4.06 \mathrm{E}-16$ \\
\hline Te-131m & $5.45 \mathrm{E}-15$ \\
\hline Te-132 & $8.03 \mathrm{E}-15$ \\
\hline Te-133 & $7.84 \mathrm{E}-17$ \\
\hline Te-133m & $3.68 \mathrm{E}-16$ \\
\hline Te-134 & $1.08 \mathrm{E}-16$ \\
\hline Th-226 & $2.98 \mathrm{E}-14$ \\
\hline Th-227 & $1.38 \mathrm{E}-11$ \\
\hline Th-228 & $2.13 \mathrm{E}-10$ \\
\hline Th-229 & $1.83 \mathrm{E}-09$ \\
\hline Th-230 & $2.77 \mathrm{E}-10$ \\
\hline Th-231 & $7.46 \mathrm{E}-16$ \\
\hline Th-232 & 1.39E-09 \\
\hline Th-234 & $2.98 \mathrm{E}-14$ \\
\hline Ti-44 & $8.66 \mathrm{E}-13$ \\
\hline Ti-45 & $1.83 \mathrm{E}-16$ \\
\hline Tl-194 & $7.84 \mathrm{E}-18$ \\
\hline Tl-194m & $3.81 \mathrm{E}-17$ \\
\hline Tl-195 & $3.94 \mathrm{E}-17$ \\
\hline Tl-197 & $4.22 \mathrm{E}-17$ \\
\hline Tl-198 & $1.40 \mathrm{E}-16$ \\
\hline Tl-198m & $9.10 \mathrm{E}-17$ \\
\hline Tl-199 & $5.92 \mathrm{E}-17$ \\
\hline Tl-200 & $4.00 \mathrm{E}-16$ \\
\hline Tl-201 & $2.00 \mathrm{E}-16$ \\
\hline T1-202 & $8.38 \mathrm{E}-16$ \\
\hline Tl-204 & $2.05 \mathrm{E}-15$ \\
\hline Tm-162 & $1.87 \mathrm{E}-17$ \\
\hline Tm-166 & $3.21 \mathrm{E}-16$ \\
\hline Tm-167 & $2.51 \mathrm{E}-15$ \\
\hline
\end{tabular}

\begin{tabular}{|c|c|}
\hline \multicolumn{2}{|c|}{$\begin{array}{l}\text { Nuclide CONVERSION } \\
\text { FACTORS ---- PE-g / Bq }\end{array}$} \\
\hline Tm-170 & $2.24 \mathrm{E}-14$ \\
\hline Tm-171 & $7.78 \mathrm{E}-15$ \\
\hline Tm-172 & $4.16 \mathrm{E}-15$ \\
\hline Tm-173 & $4.09 \mathrm{E}-16$ \\
\hline Tm-175 & $1.97 \mathrm{E}-17$ \\
\hline U-230 & $1.66 \mathrm{E}-11$ \\
\hline U-231 & $1.01 \mathrm{E}-15$ \\
\hline U-232 & $5.60 \mathrm{E}-10$ \\
\hline U-233 & $1.15 \mathrm{E}-10$ \\
\hline U-234 & $1.13 \mathrm{E}-10$ \\
\hline U-235 & $1.05 \mathrm{E}-10$ \\
\hline U-236 & $1.07 \mathrm{E}-10$ \\
\hline U-237 & $3.00 \mathrm{E}-15$ \\
\hline U-238 & $1.02 \mathrm{E}-10$ \\
\hline U-239 & $3.18 \mathrm{E}-17$ \\
\hline U-240 & $1.93 \mathrm{E}-15$ \\
\hline V-47 & $5.98 \mathrm{E}-17$ \\
\hline$V-48$ & $8.69 \mathrm{E}-15$ \\
\hline $\mathrm{V}-49$ & $2.94 \mathrm{E}-16$ \\
\hline W-176 & $9.07 \mathrm{E}-17$ \\
\hline W-177 & $5.54 \mathrm{E}-17$ \\
\hline W-178 & $2.30 \mathrm{E}-16$ \\
\hline W-179 & $2.98 \mathrm{E}-18$ \\
\hline W-181 & $1.29 \mathrm{E}-16$ \\
\hline W-185 & $6.39 \mathrm{E}-16$ \\
\hline W-187 & $5.26 \mathrm{E}-16$ \\
\hline W-188 & $3.50 \mathrm{E}-15$ \\
\hline $\mathrm{Xe}-120$ & $2.21 \mathrm{E}-16$ \\
\hline Xe-121 & $9.70 \mathrm{E}-16$ \\
\hline $\mathrm{Xe}-122$ & $2.96 \mathrm{E}-17$ \\
\hline $\mathrm{Xe}-123$ & $3.37 \mathrm{E}-16$ \\
\hline $\mathrm{Xe}-125$ & $1.45 \mathrm{E}-16$ \\
\hline $\mathrm{Xe}-127$ & $1.55 \mathrm{E}-16$ \\
\hline $\mathrm{Xe}-129 \mathrm{~m}$ & $1.28 \mathrm{E}-17$ \\
\hline $\mathrm{Xe}-131 \mathrm{~m}$ & $4.66 \mathrm{E}-18$ \\
\hline Xe-133 & $1.91 \mathrm{E}-17$ \\
\hline $\mathrm{Xe}-133 \mathrm{~m}$ & $1.69 \mathrm{E}-17$ \\
\hline Xe-135 & $1.47 \mathrm{E}-16$ \\
\hline $\mathrm{Xe}-135 \mathrm{~m}$ & $2.37 \mathrm{E}-16$ \\
\hline Xe-138 & $6.05 \mathrm{E}-16$ \\
\hline Y-86 & $1.46 \mathrm{E}-15$ \\
\hline Y-86m & $8.47 \mathrm{E}-17$ \\
\hline Y-87 & $1.49 \mathrm{E}-15$ \\
\hline Y-88 & $2.39 \mathrm{E}-14$ \\
\hline Y-90 & $7.18 \mathrm{E}-16$ \\
\hline Y-90m & $4.00 \mathrm{E}-16$ \\
\hline $\mathrm{Y}-91$ & $4.16 \mathrm{E}-14$ \\
\hline Y-91m & $3.09 \mathrm{E}-17$ \\
\hline Y-92 & $6.64 \mathrm{E}-16$ \\
\hline Y-93 & $1.83 \mathrm{E}-15$ \\
\hline
\end{tabular}




\begin{tabular}{|c|c|}
\hline \multicolumn{2}{|c|}{$\begin{array}{l}\text { Nuclide CONVERSION } \\
\text { FACTORS ---- PE-g / Bq }\end{array}$} \\
\hline Y-94 & $5.95 \mathrm{E}-17$ \\
\hline Y-95 & $3.21 \mathrm{E}-17$ \\
\hline Yb-162 & $1.90 \mathrm{E}-17$ \\
\hline Yb-166 & $2.53 \mathrm{E}-15$ \\
\hline Yb-167 & $7.12 \mathrm{E}-18$ \\
\hline Yb-169 & $6.86 \mathrm{E}-15$ \\
\hline Yb-175 & $1.38 \mathrm{E}-15$ \\
\hline Yb-177 & $1.24 \mathrm{E}-16$ \\
\hline Yb-178 & $1.38 \mathrm{E}-16$ \\
\hline Zn-62 & $1.75 \mathrm{E}-15$ \\
\hline $\mathrm{Zn}-63$ & $6.93 \mathrm{E}-17$ \\
\hline $\mathrm{Zn}-65$ & $1.73 \mathrm{E}-14$ \\
\hline Zn-69 & $3.34 \mathrm{E}-17$ \\
\hline $\mathrm{Zn}-69 \mathrm{~m}$ & $6.93 \mathrm{E}-16$ \\
\hline $\mathrm{Zn}-71 \mathrm{~m}$ & $3.31 \mathrm{E}-16$ \\
\hline $\mathrm{Zn}-72$ & $4.25 \mathrm{E}-15$ \\
\hline $\mathrm{Zr}-86$ & $1.87 \mathrm{E}-15$ \\
\hline $\mathrm{Zr}-88$ & $2.07 \mathrm{E}-14$ \\
\hline Zr-89 & $2.02 \mathrm{E}-15$ \\
\hline Zr-93 & $2.73 \mathrm{E}-13$ \\
\hline Zr-95 & $2.01 \mathrm{E}-14$ \\
\hline $\mathrm{Zr}-97$ & $3.68 \mathrm{E}-15$ \\
\hline
\end{tabular}




\section{Appendix C}

\section{Marking and Labeling}


This page intentionally left blank 


\section{Appendix C - Marking and Labeling}

\section{C.1 Barcode}

Barcodes (see Figure C-1) used on packages must meet the following standards: ${ }^{7.6}$
A. Code 39 .

B. Low- to medium density; low-density preferred.

C. 1-inch high bar code not to exceed 6 inches wide.

D. Human readable interpretation (HRI) $1 / 2$ inch high, printed below the bar code.

E. Spacing between bar code and HRI will be $1 / 10$ of an inch.

F. Minimum left and right margin (quiet zones) will be at least 1/25 inch.

G. Bar codes and HRI will be stacked with a minimum separation of $1 / 2$ inch and in the following order: shipment number, container number.

H. A total of two bar code labels must be placed on each package near the top and on opposite sides. ${ }^{7.6}$ Drums must have a total of two bar code labels, one on top of the drum lid and one on the side near the top.

Note: Exceptions to these requirements must be verified with the RWMC operations prior to shipment.

I. Labels shall be securely attached and able to satisfy the following:

- Weatherproof (must not deform when wet or fade in the sun)

- Resistant to tearing, peeling, and cracking

- Print must be with permanent indelible ink and legible

A sample bar code must be submitted to BN prior to the first shipment to ensure that the RWMC equipment can be used to read the bar code." 


\section{Figure C-1: Bar Code Label Example}

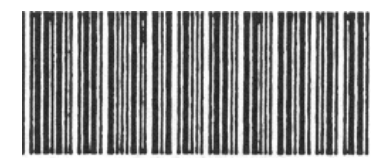 \\ MDL02001 \\ 000001}

Note: Example not actual size.

\section{C.2 Marking and Labeling}

Packages must have the following markings and labels: ${ }^{7.6}$

A. Marking and labeling as required in Title 49 CFR;

B. For additional asbestos labeling, see Section 3.1.15.

C. For additional beryllium labeling, see Section 3.1.17.

D. For additional MW labeling, see Section 3.3.6.1

E. "Package Certification Label" (PCL) (see Figure C-2), signed by the Waste Certification Official or package certifier. ${ }^{6.217 .6}$ If the waste is unpackaged bulk, a signed PCL must accompany the shipment papers.

F. Shipment number in the following sequence: Two alpha character generator-site-designator codes assigned by NNSA/NSO/WMD (see Section C-3); one alpha character for type of waste (L for LLW, M for MW); two numerical characters for current fiscal year; three alpha numerical characters for shipment sequence. This number must be on the bar code. ${ }^{7.6}$ Example: MDL99001 indicates a shipment from the Mound Facility of LLW in fiscal year 1999 and the first shipment. 
G. Package number must be six characters (alpha, numeric, or combination) with no duplication within the shipment. ${ }^{7.6}$ This number must be on the bar code.

H. Package weight in units of kilograms and pounds must be included on the side of each waste package. ${ }^{7.6}$ This requirement can be met through the use of a label, additions to bar code labels, or by writing the weight on the side of the waste package.

\section{Figure C-2: Package Certification Label}

NV-211 October 2005

PACKAGE CERTIFICATION LABEL

USDOE

This label certifies this container and its contents meet the requirements of DOT (49 CFR), EPA (40 CFR), and NTSWAC for transportation and disposal.

PACKAGE NUMBER:

DATE:

CERTIFIED BY (print):

CERTIFIED BY (signature):

Waste Certification Official

Alternate Waste Certification Official

Package Certifier

RWMC DESIGNATION (i.e. ONLO, ARIR): 


\section{C.3 Generator Waste Stream and Shipment Codes}

\section{GENERATOR}

Aberdeen Proving Ground

Argonne National Lab

Bechtel - NTS

Boeing

Brookhaven National Lab

BWXT Y-12

Duratek

Fernald

Foster Wheeler

GA Technologies

INL

Kansas City

LANL

LLNL

Lovelace Foundation

Mound

Nuclear Fuel Services

Oak Ridge Reservation

Paducah

Pantex

Permafix (M\&EC)

Portsmouth

Princeton Plasma Physics Lab

RMI Environmental Services

Rocky Flats

Sandia - Albuquerque

Sandia - California

Savannah River

Stoller -Navarro

UT-Battelle

West Valley

\author{
RWMC \\ DESIGNATION
}

USAA

ANLE

LRY5

BNRC

BNLX

BWXT

DRTK

ONLO

FWOR

BGAT

INEL

ABXK

LANL

BCLA

ALVI

AMDM

NFSI

ORTN

PGDP

AMHP

PERM

PORT

PPPL

ORMI

ARIR

ASLA

ASLL

SVRS

LITN

ORNL

WVDP

\section{SITE DESIGNATOR}

AP

AE

DP

$\mathrm{BN}$

BR

BW

DR

WM

FW

BG

IN

AS

LA

LL

LV

MD

NF

OR

PD

PX

PF

PO

PL

RM

RF

SA

SL

SR

IT

UT

WV

Note: If generator site is not listed, develop designations and submit with first waste profiles. A database verification of uniqueness will be conducted by RWAP. 


\section{C.4 NTS Advance Shipment Notification \\ Nevada Test Site \\ Advance Shipment Notification}

Shipper Name and Address:

Contact Name:

Phone/Pager:

Waste Stream

Number(s):

Shipment Number:

Shipment Departure Date: Time:

Estimated Arrival Date: Time:

Carrier: Driver's Name:

Driver's License No. State:

Tractor License No. Trailer No. Seal No.

Gross Wt. (Lbs) : Type/Number of Packages: Box Drum

Bulk (cargo containers, equipment, burrito wraps, etc..) Other

DOT Proper Shipping Name(s) or Attached Bill of Lading:

Special Handling Considerations:

[ ] Asbestos [ ] Classified [ ] Mixed Waste [ ] Other:

Attachments:

[ ] PSDR [ ] Bill of Lading [ ] Other:

Privacy Act Statement: The information on this form is protected by the Privacy Act of 1974. The purpose of requesting this information is to comply with the terms and conditions under which the Nevada Test Site will accept low-level radioactive waste and mixed waste for disposal. This information will be used by the U.S. Department of Energy, National Nuclear Security Administration Nevada Site Office and its contractors. Failure to provide this information will result in either a delay in waste receipt or waste refusal at the Nevada Test Site.

PRIVACY ACT INFORMATION 
This page intentionally left blank. 


\section{Appendix D}

\section{Package Storage and Disposal Request}


This page intentionally left blank 


\section{Appendix D -Package Storage and Disposal Request}

\section{Package Storage and Disposal Request, Revision 1}

The activity of each nuclide in a waste package as documented on the Package Storage and Disposal Request (PSDR) shall not exceed the corresponding maximum radionuclide

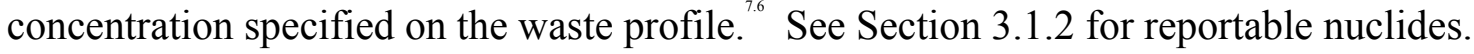

Shipment Number:

Prepared By:

Date:

Manifest No:

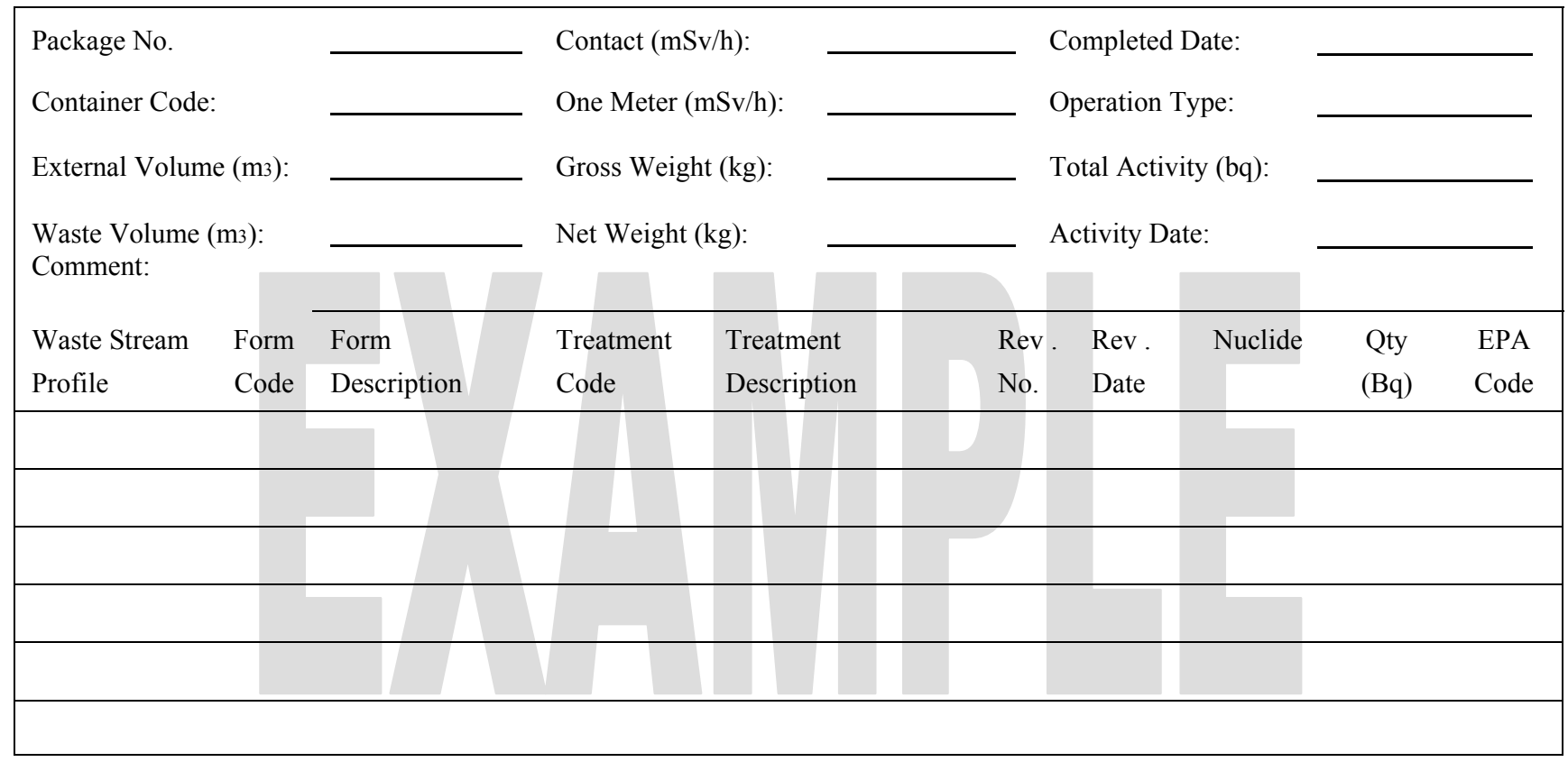

If you have any questions on completing this document, contact the BN Waste Management Department at (702) 295-6811. Data entered on the form must be legible. Hand-printing or typing of letters and numbers is preferred to handwriting. When using a decimal, it must be clearly defined. DO NOT USE COMMAS! 
PSDR Instructions

SHIPMENT NUMBER: Consists of eight alphanumeric characters. Enter the shipment number in the following sequence: two-digit generator code assigned by WMD, L (low-level) or M (mixed), last two digits of the current fiscal year (Oct. 1 - Sept. 30), and the consecutive number of shipments from the generating facility. EXAMPLE: DPL90001 represents Decon Pad, low-level waste, fiscal year 1990, and the first shipment sent to WMD for fiscal year 1990. The shipment number must be eight characters in the above sequence.

MANIFEST NUMBER: Required only on mixed waste shipments; a five digit number

PACKAGE NUMBER: $\quad$ Six unique characters for each container in the shipment. See the instructions on the comment field for required information for previously rejected packages.

CONTACT:

Maximum radiation reading at the surface of the package in $\mathrm{mSv} / \mathrm{H}$ : Written in scientific notation X.XXXE \pm 00 .

COMPLETION DATE: The date, in the formal DDMMMYYYY (e.g., 01Jan1992), that the last waste material was placed in the package.

CONTAINER CODE: Three digit number that identifies the type of container. If your container is not listed, contact the RWMC at (702) 295-6811.

\begin{tabular}{|c|c|c|c|c|c|c|}
\hline \multirow[b]{2}{*}{ Code } & \multirow[b]{2}{*}{ Description } & \multirow[b]{2}{*}{ Length } & \multirow[b]{2}{*}{ Width } & \multirow[b]{2}{*}{ Height } & \multicolumn{2}{|c|}{ External Volume } \\
\hline & & & & & Cubic Feet & Cubic Meters \\
\hline 100 & Miscellaneous & $\mathrm{N} / \mathrm{A}$ & N/A & N/A & N/A & $\mathrm{N} / \mathrm{A}$ \\
\hline 101 & 30-gallon drum & N/A & N/A & N/A & $4.99-6.99$ & $0.141-0.1979$ \\
\hline 102 & 55-gallon drum & $\mathrm{N} / \mathrm{A}$ & N/A & N/A & $7.99-9.99$ & $0.226-0.283$ \\
\hline 124 & 85-gallon drum & $\mathrm{N} / \mathrm{A}$ & N/A & N/A & $12.99-14.99$ & $0.368-0.424$ \\
\hline 125 & 110-gallon drum & $\mathrm{N} / \mathrm{A}$ & N/A & N/A & 18.99-20.99 & $0.537-0.594$ \\
\hline *200 & Half box & $78 "-90 "$ & $42 "-56 "$ & $18 "-30 "$ & $34.125-87.5$ & $0.9663-2.4777$ \\
\hline *201 & Wooden half box & $78 "-90 "$ & $42^{\prime \prime}-56^{\prime \prime}$ & $18^{\prime \prime}-30 "$ & $34.125-87.5$ & $0.9663-2.4777$ \\
\hline *210 & Full box & $78 "$ - 90" & $42 "$ - 56" & $42 "-56 "$ & $79.625-163.33$ & $2.2547-4.6250$ \\
\hline *211 & Wooden full box & $78^{\prime \prime}-90^{\prime \prime}$ & $42 "-56^{\prime \prime}$ & $42^{\prime \prime}-56^{\prime \prime}$ & $79.625-163.33$ & $2.2547-4.6250$ \\
\hline *220 & Cargo Container & 234" - 246" & $90 "-102 "$ & $90 "$ - 102" & $1,096.875-1,481.125$ & $31.060-41.940$ \\
\hline *230 & Supersack & N/A & N/A & N/A & N/A & N/A \\
\hline 240 & Burrito $\mathrm{W}$ rap & N/A & N/A & N/A & $\mathrm{N} / \mathrm{A}$ & N/A \\
\hline 250 & Concrete Monolith & $\mathrm{N} / \mathrm{A}$ & N/A & N/A & $149.734-199.987$ & $4.24-5.663$ \\
\hline
\end{tabular}

*External volumes reported for containers using these codes must be based on the containers' external dimensions. Volume should be within range specified.

1 METER: $\quad$ Maximum radiation reading at 1 meter in $\mathrm{mSv} / \mathrm{h}$ : Written in scientific notation X.XXXE \pm 00 .

OPERATION TYPE: $\quad$ B for burial, or R for retrievable. 
EXTERNAL VOLUME: Total volume displaced by the container in cubic meters. Refer to CONTAINER CODE. Written in scientific notation X.XXXE \pm 00 .

GROSS WEIGHT: $\quad$ Total weight of container including waste and solidification or absorbent media in kilograms. Written in scientific notation $\mathrm{X} . \mathrm{XXXE} \pm 00$.

TOTAL ACTIVITY: $\quad$ Total Becquerels; must equal the sum of becquerels for each nuclide reported. Written in scientific notation X.XXXE \pm 00 .

WASTE VOLUME: Actual volume of waste material in package in cubic meters. Written in scientific notation X.XXXE+00.

NET WEIGHT: $\quad$ Total weight of waste and solidification or absorbent media, excluding container, in kilograms. Written in scientific notation X.XXXE \pm 00 .

ACTIVITY DATE: $\quad$ The date, in the formal DDMMMYYYY (e.g., 01Jan1992), that the activity of the package was determined.

COMMENT: If the package was rejected from NTS and is being re-shipped to NTS, the original package number of the previously rejected package (parent) must be entered in parentheses. All packages generated from the repackaging of the rejected waste (progeny) shall have the original rejected package number (parent) entered in parentheses in the comment section.

WASTE STREAM / PROFILE:

Waste Stream Identification or profile number. Thirteen alphanumeric characters. First four characters will be the RWMC designation. Next nine alphanumeric characters will be assigned by the generator. EXAMPLE: LRY5000000001 represents waste from the NTS.

WASTE FORM CODES: Enter the appropriate three-digit number that categorizes the waste in the package.

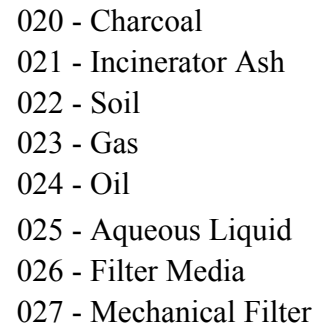

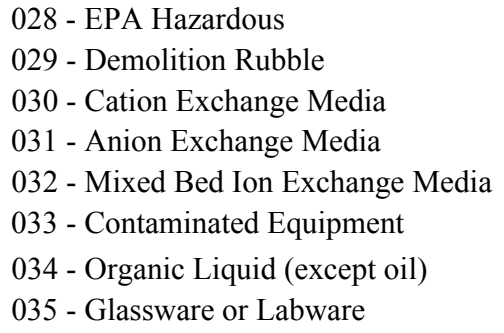

\author{
036 - Sealed Source or Device \\ 037 - Paint or Plating \\ 038 - Evaporator Bottoms /Sludges /Concentrates \\ 039 - Compactable Trash \\ 040 - Noncompactable Trash \\ 041 - Animal Carcasses \\ 042 - Biological Material (except animal carcasses) \\ 043 - Activated Material \\ 044 - Other (Describe)
}


WASTE TREATMENT CODES: Enter the appropriate three-digit number that categorizes which waste treatment was used on the waste in the package

\begin{tabular}{|c|c|c|c|c|c|}
\hline \multicolumn{4}{|c|}{ Sorption } & \multicolumn{2}{|c|}{$\underline{\text { Solidification }}$} \\
\hline $060-$ & Speedi Dri & $071-$ & Chemsil3030 & 090 - & Cement \\
\hline 061 - & Celetom & $072-$ & Dicaperl HP200 & 091 - & Concrete Encapsulation \\
\hline $062-$ & Floor Dry/Superfine & $073-$ & Dicaperl HP500 & 092 - & Bitumen \\
\hline $063-$ & HiDri & $074-$ & Zonolite Gd4 & $093-$ & Vinyl Toluene \\
\hline $064-$ & Safe T Sorb & $075-$ & Petroset & 094 - & Vinyl Ester Styrene \\
\hline $065-$ & Safe N D ry & $076-$ & Petroset II & 095 - & Other (Describe) \\
\hline $066-$ & Florco & $077-$ & Aquaset & $100-$ & No Sorption or Solidification \\
\hline 067- & Florco X & $078-$ & Aquaset II & & \\
\hline $068-$ & Solid A Sorb & $079-$ & Other (Describe) & & \\
\hline $069-$ & Chemsil 30 & $\underline{080}$ & Quicksolid & & \\
\hline $\begin{array}{l}070- \\
\text { Mixed }\end{array}$ & Chemsil 50 & & & & \\
\hline $\begin{array}{ll}\text { Nilxea } \\
101\end{array}$ & ste & & & & \\
\hline 102 & CARBN & & & & \\
\hline 103 & CHOXD & & & & \\
\hline 104 & CHRED & & & & \\
\hline 105 & CMBST & & & & \\
\hline 106 & DEACT & & & & \\
\hline 107 & MACRO & & & & \\
\hline 108 & STABL & & & & \\
\hline 109 & Other (Provide LDR & ed Tre & nt Technology Code & & \\
\hline 110 & Meets Concentration & LDR s & $\operatorname{ards}$ & & \\
\hline
\end{tabular}

REVISION: $\quad$ WP Revision number found in Section B.1 of the approved profile: profile revision must be a two-digit number.

REVISION DATE: WP Date found in Section B.1 of the approved profile: in the formal DDMMMYYYY (e.g., 01Jan1992).

NUCLIDE: $\quad$ Valid nuclide description. Attach additional sheet to report more nuclides than space allows. Dash (-) format is required for identifying radionuclides (e.g., $\mathrm{Cs}-137$ and $\mathrm{Pu}-239)$.

QUANTITY: $\quad$ The quantity of the nuclide present in the container in Becquerels. The sum of each nuclide reported must not exceed the total activity reported for the total package. Written in scientific notation X.XXXE \pm 00 .

EPA CODE: $\quad$ For mixed waste containers, enter the EPA Hazardous Waste Number associated with the package. Enter "STHW" if the container is mixed waste with a State hazardous waste number and not a federal EPA Hazardous Waste Number. 


\section{Appendix E}

\section{Radiological Waste Characterization and Reporting Requirements}


This page intentionally left blank. 


\section{Appendix E - Radiological Waste Characterization and Reporting Requirements}

\section{E.1 Radionuclide Reporting}

Reportable radionuclides shall be reported on the Waste Profile (WP) and Package Storage and Disposal Request (PSDR). ${ }^{6.1775}$ The WP is applied at a waste stream level. The PSDR is applied at a waste package level. Any radionuclides reported on the PSDR must also be identified on the WP. ${ }^{75}$ (See Appendix D for example of the PSDR.)

\section{A. Reportable Radionuclides}

Radionuclides known or reasonably expected to be present in a waste stream shall be reported as follows:"

1. The activity concentration of the radionuclides in the final waste form exceeds 1 percent of the Action Level (Table E-1). ${ }^{6.779}$ These radionuclides require rigorous waste characterization and shall be reported on the PSDR and the WP. 7.5

2. Radionuclides that are alpha-emitting and transuranic with a half-life greater than 20 years, that exceed $10 \mathrm{pCi} / \mathrm{g}$ shall be reported on the WP. ${ }^{7.5}$ The waste mass must be determined as described in Section E.4. ${ }^{7.5}$ Transuranic waste radionuclides with concentrations that exceed $1 \mathrm{nCi} / \mathrm{g}$ require rigorous waste characterization methods and shall be reported on the PSDR and the WP.

3. Activity concentrations in the final waste form that exceed 1 percent of the total activity concentration shall be reported on the PSDR and the WP. ${ }^{7.5}$ The total activity concentration shall include the activity of all radionuclides, except for those that are exempt from the reporting requirements as specified $^{6.77 .9}$ For these radionuclides and for those present at a level less than the detection limit of industry-accepted characterization methods, Process Knowledge (PK) should be sufficient for characterization. 
Table E-1: Radionuclide Action Levels for Waste Characterization and Reporting

\begin{tabular}{|c|c|c|c|}
\hline Nuclide & $\begin{array}{c}\text { Action Level } \\
\text { (Bq m-3) }\end{array}$ & Nuclide & $\begin{array}{c}\text { Action Level } \\
(\mathbf{B q} \mathrm{m}-3)\end{array}$ \\
\hline $\begin{array}{l}\text { Unlisted nuclide } \\
\text { with a } t_{1 / 2}<5 \mathrm{yr}\end{array}$ & No Limit & ${ }^{227} \mathrm{Ac}$ & $1.0 \times 10^{12}$ \\
\hline${ }^{3} \mathrm{H}$ & $5.6 \times 10^{15}$ & ${ }^{229} \mathrm{Th}$ & $4.1 \times 10^{9}$ \\
\hline${ }^{14} \mathrm{C}$ & $2.3 \times 10^{8}$ & ${ }^{230} \mathrm{Th}$ & $9.6 \times 10^{7}$ \\
\hline${ }^{36} \mathrm{Cl}$ & $1.1 \times 10^{10}$ & ${ }^{232} \mathrm{Th}$ & $8.1 \times 10^{8}$ \\
\hline${ }^{59} \mathrm{Ni}$ & $8.1 \times 10^{12}$ & ${ }^{231} \mathrm{~Pa}$ & $1.4 \times 10^{9}$ \\
\hline${ }^{63} \mathrm{Ni}$ (activated metal) & $2.5 \times 10^{14}$ & ${ }^{232} \mathrm{U}$ & $9.3 \times 10^{9}$ \\
\hline${ }^{63} \mathrm{Ni}$ & $2.5 \times 10^{13}$ & ${ }^{233} \mathrm{U}$ & $3.1 \times 10^{10}$ \\
\hline${ }^{60} \mathrm{Co}$ & No Limit & ${ }^{234} \mathrm{U}$ & $1.9 \times 10^{10}$ \\
\hline${ }^{90} \mathrm{Sr}$ & $1.5 \times 10^{12}$ & ${ }^{235} \mathrm{U}$ & $1.2 \times 10^{10}$ \\
\hline${ }^{93} \mathrm{Zr}$ & $1.4 \times 10^{13}$ & ${ }^{236} \mathrm{U}$ & $1.2 \times 10^{11}$ \\
\hline${ }^{99} \mathrm{Tc}$ & $1.1 \times 10^{11}$ & ${ }^{238} \mathrm{U}$ & $5.9 \times 10^{10}$ \\
\hline${ }^{107} \mathrm{Pd}$ & $1.3 \times 10^{14}$ & ${ }^{237} \mathrm{~Np}$ & $7.0 \times 10^{8}$ \\
\hline${ }^{126} \mathrm{Sn}$ & $5.9 \times 10^{8}$ & ${ }^{236} \mathrm{Pu}$ & $2.3 \times 10^{11}$ \\
\hline${ }^{129} \mathrm{I}$ & $2.9 \times 10^{9}$ & ${ }^{238} \mathrm{Pu}$ & $1.2 \times 10^{11}$ \\
\hline${ }^{133} \mathrm{Ba}$ & No Limit & ${ }^{239} \mathrm{Pu}$ & $2.3 \times 10^{10}$ \\
\hline${ }^{135} \mathrm{Cs}$ & $2.8 \times 10^{12}$ & ${ }^{240} \mathrm{Pu}$ & $2.3 \times 10^{10}$ \\
\hline${ }^{137} \mathrm{Cs}$ & $3.4 \times 10^{11}$ & ${ }^{241} \mathrm{Pu}$ & $5.2 \times 10^{11}$ \\
\hline${ }^{151} \mathrm{Sm}$ & $1.2 \times 10^{15}$ & ${ }^{242} \mathrm{Pu}$ & $2.4 \times 10^{10}$ \\
\hline${ }^{152} \mathrm{Eu}$ & $4.8 \times 10^{13}$ & ${ }^{241} \mathrm{Am}$ & $1.8 \times 10^{10}$ \\
\hline${ }^{154} \mathrm{Eu}$ & $1.2 \times 10^{16}$ & ${ }^{243} \mathrm{Am}$ & $7.0 \times 10^{9}$ \\
\hline${ }^{210} \mathrm{~Pb}$ & $1.3 \times 10^{13}$ & ${ }^{242} \mathrm{Cm}$ & $2.4 \times 10^{13}$ \\
\hline${ }^{207} \mathrm{Bi}$ & $1.1 \times 101^{1}$ & ${ }^{244} \mathrm{Cm}$ & $8.1 \times 10^{12}$ \\
\hline${ }^{226} \mathrm{Ra}$ & $3.6 \times 10^{7}$ & ${ }^{248} \mathrm{Cm}$ & $6.3 \times 10^{9}$ \\
\hline${ }^{228} \mathrm{Ra}$ & No Limit & & \\
\hline
\end{tabular}




\section{B. Exempt Radionuclides}

Radionuclides meeting any of the following criteria are exempt from the reporting requirements:

1. Any radionuclide, as listed in Table E-2, that will reach a state of transient or secular equilibrium with a parent radionuclide within the operational period of the disposal site.

2. Any radionuclide occurring at activity concentrations not exceeding background ranges for the region in which it was generated and material of interest.

\section{Table E-2: Exempt Radionuclides}

The progeny radionuclides listed are exempt from reporting requirements when a parent radionuclide is present.

\begin{tabular}{|l||}
\hline${ }^{90} \mathrm{Y},{ }^{93} \mathrm{Nb},{ }^{126 \mathrm{~m}} \mathrm{Sb},{ }^{126} \mathrm{Sb},{ }^{137 \mathrm{~m}} \mathrm{Ba}$ \\
${ }^{233} \mathrm{~Pa},{ }^{225} \mathrm{Ra},{ }^{225} \mathrm{Ac},{ }^{221} \mathrm{Fr},{ }^{217} \mathrm{At},{ }^{213} \mathrm{Bi},{ }^{213} \mathrm{Po},{ }^{209} \mathrm{Tl},{ }^{209} \mathrm{~Pb}$ \\
\hline${ }^{239} \mathrm{~Np},{ }^{231} \mathrm{Th},{ }^{227} \mathrm{Th},{ }^{223} \mathrm{Fr},{ }^{223} \mathrm{Ra},{ }^{219} \mathrm{Rn},{ }^{215} \mathrm{Po},{ }^{211} \mathrm{~Pb},{ }^{211} \mathrm{Bi},{ }^{211} \mathrm{Po},{ }^{207} \mathrm{Tl}$ \\
\hline${ }^{234} \mathrm{Th},{ }^{234 \mathrm{~m}} \mathrm{~Pa},{ }^{234} \mathrm{~Pa},{ }^{222} \mathrm{Rn},{ }^{218} \mathrm{Po},{ }^{214} \mathrm{~Pb},{ }^{214} \mathrm{Bi},{ }^{214} \mathrm{Po},{ }^{210} \mathrm{Bi},{ }^{210} \mathrm{Po}$ \\
\hline${ }^{240} \mathrm{U},{ }^{240 \mathrm{~m}} \mathrm{~Np},{ }^{240} \mathrm{~Np},{ }^{228} \mathrm{Ra},{ }^{228} \mathrm{Ac},{ }^{228} \mathrm{Th},{ }^{224} \mathrm{Ra},{ }^{220} \mathrm{Rn},{ }^{216} \mathrm{Po},{ }^{212} \mathrm{~Pb},{ }^{212} \mathrm{Bi},{ }^{212} \mathrm{Po},{ }^{208} \mathrm{Tl}$ \\
\hline
\end{tabular}

\section{E.2 Waste Profile Instructions}

The reported activity concentrations must be representative of the final waste form after treatment or stabilization. ${ }^{7.5}$ Zero will not be accepted as the lower limit value. The lower limit must be set as the expected lower limit concentration or as the lower limit of detection (LLD) of the characterization method. ${ }^{7.5}$ If the lower limit is set by the LLD, list the lower limit value in parenthesis. Waste packages exceeding the upper limit will not be accepted for disposal without prior approval of a revised waste profile. The waste concentration may be less than the lower limit without prior approval. 


\section{E.3 Radiological Characterization Methods}

Waste characterization methods are described below and are not intended to be allinclusive. These methods can be used individually or in combination. The NNSA/NSO will use a graded approach in its acceptance of waste characterization methods. Generators are encouraged to develop innovative waste characterization plans designed for the specific conditions at their facilities.

The acceptability of a generator's waste characterization plan will be based on a determination that the level of effort is appropriate, given the potential of the waste stream to exceed the waste concentration action levels (Table E-1) and the physical limitations of the waste stream. Physical limitations may include waste matrices that cannot be representatively sampled because of unreasonable radiation exposure. Generators are expected to identify, based on knowledge of their processes and facility, those radionuclides with a reasonable probability of exceeding 1 percent of the waste concentration action level. Waste streams or waste packages reasonably expected to exceed 1 percent of the waste concentration action levels (Table E-1) will require the greatest level of characterization and verification.

\section{A. Materials Controls and Accountability (MC\&A)}

MC\&A records are data developed from a mass balance of material entering and exiting a process. MC\&A data can be used to estimate the activity concentration of waste streams. This method is expected to be most useful for generators possessing limited numbers of nuclides, such as special nuclear materials, in known activity concentrations.

\section{B. Gross Radiation Measurements}

Scaling factors can be developed that relate gross radiation measurements to the activity concentration of a waste stream. Generators using gross radiation measurements shall ensure that measurements correlate with activity concentration on a consistent basis. ${ }^{7.8}$ Radionuclide distributions in the waste stream shall be initially determined and periodically verified through direct measurements or sampling and analysis. ${ }^{7.8}$ Generators shall document all methods used to develop scaling factors which relate gross radiation measurements to the activity concentration. ${ }^{7.8}$ When developing scaling factors, generators must consider the waste package and detector geometry, shielding and attenuation effects, self-absorption, and the energy spectra and decay schemes of radionuclides in the waste. 


\section{Direct Measurement of Specific Radionuclides}

Direct measurement of radionuclides may include nondestructive analysis of waste packages. In using this method, individual radionuclides are measured.

\section{Sampling and Analysis}

Radiological characterization using sampling and analysis, including swipes taken for characterization, shall be controlled.

\section{E. Process Knowledge}

Process knowledge will often be sufficient for characterization of radionuclides not having action levels or occurring at concentrations less than 1 percent of the action level. This method involves determining the radionuclide content of the waste through knowledge and control of the source of the waste.

\section{E.4 Determination of Waste Volume}

Waste activity concentration shall be determined based on the volume of the final waste form as offered for disposal. ${ }^{7.5}$ Measurement or analysis of samples may be performed prior to final processing if the measured activity concentration can be related to the final activity concentration. The volume of the waste can usually be taken as the internal volume of the container if the radionuclides are reasonably homogeneously distributed throughout the waste and the waste fills at least 90 percent of the waste container. When these conditions are not met, for example when the package contains significant void space or contains irregularly shaped equipment or components, the volume shall be taken as the volume occupied by the waste in the container. ${ }^{6.19}$ The activity concentration of transuranic radionuclides in units of $\mathrm{nCi} / \mathrm{g}$ shall be based on the mass of the contents of a single waste container, excluding the mass of the container and any shielding present.

\section{E.5 Examples of Waste Characterization Documentation}

A. Process knowledge documentation:

Historical analytical data, literature searches, living memory, historic records, MC\&A records, mass balance documentation, production specifications, certificates of traceability, plans and drawings, signed statements of living memory, system descriptions, work and operating procedures which generated waste, and Material Safety Data Sheets.

B. Evaluation of PK and historical data:

C. Independent review of program documents: (may be in the form of a sign-off page within the approved document). 
D. Reviewed and approved procedures: Direct measurement and/or survey processes, surface area estimations (when surface area of waste material is utilized in radiological characterization calculations), and ratio/scaling factor information (approach to ratio/scaling factor development, application of ratios/scaling factors, justification for use of ratios/scaling factors, supporting calculations, operating procedures for assay equipment).

E. Evaluated Data, Validated Data, Sampling and Analysis Plan, Scope of Work, and Laboratory Acquisition Document.

\section{E.6 Radiological Characterization Flow Diagram Overview}

Figure E-1, the radiological characterization flow diagram, illustrates the approach that should be used to obtain adequate radiological characterization. The approach allows for the utilization of generally accepted radiological characterization methodologies and documentation. Radiological characterization documentation requirements are outlined by markers (9) on the radiological characterization flow diagram. 


\section{Figure E-1: Radiological Characterization Flow Diagram}

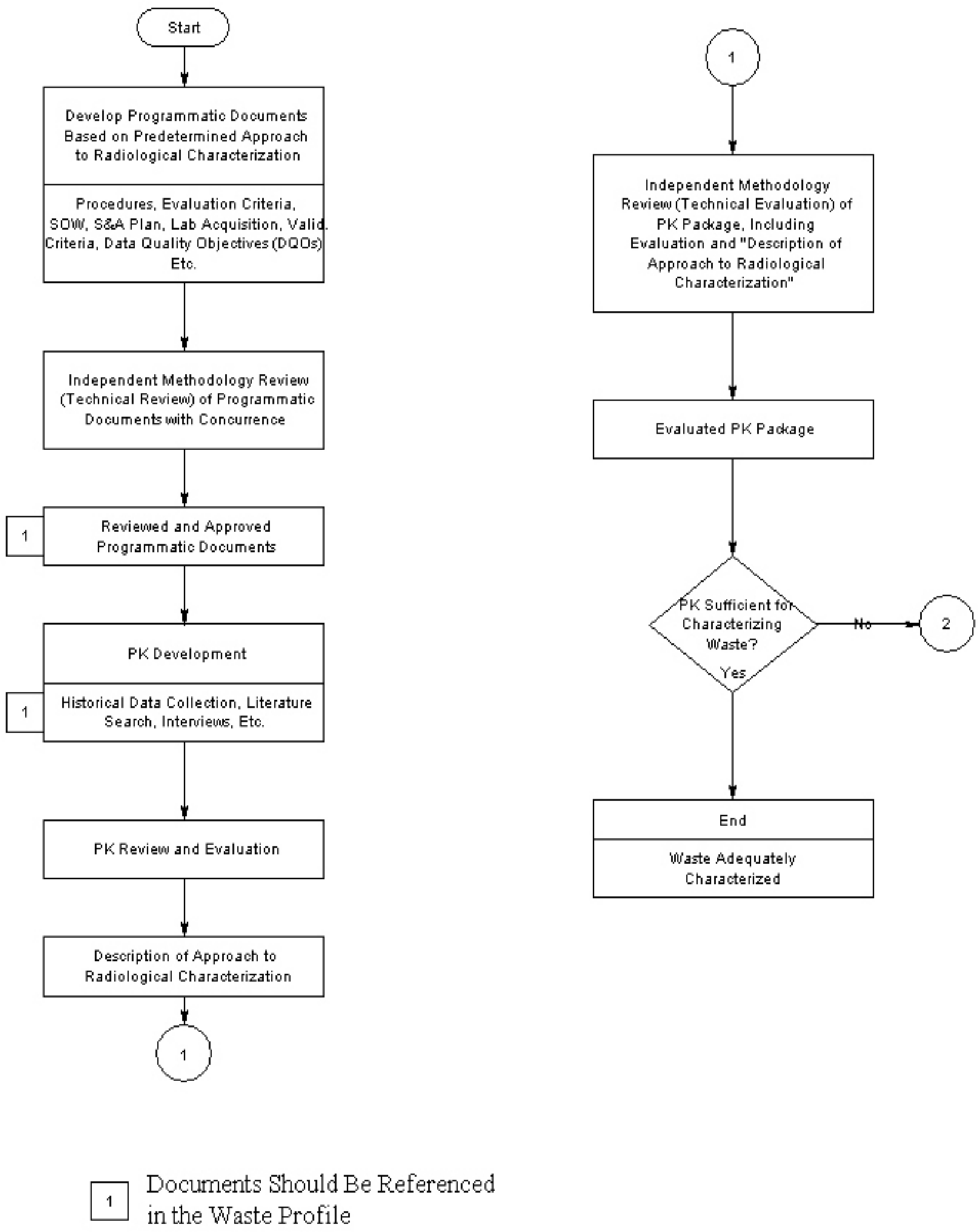


Figure E-1 (continued)
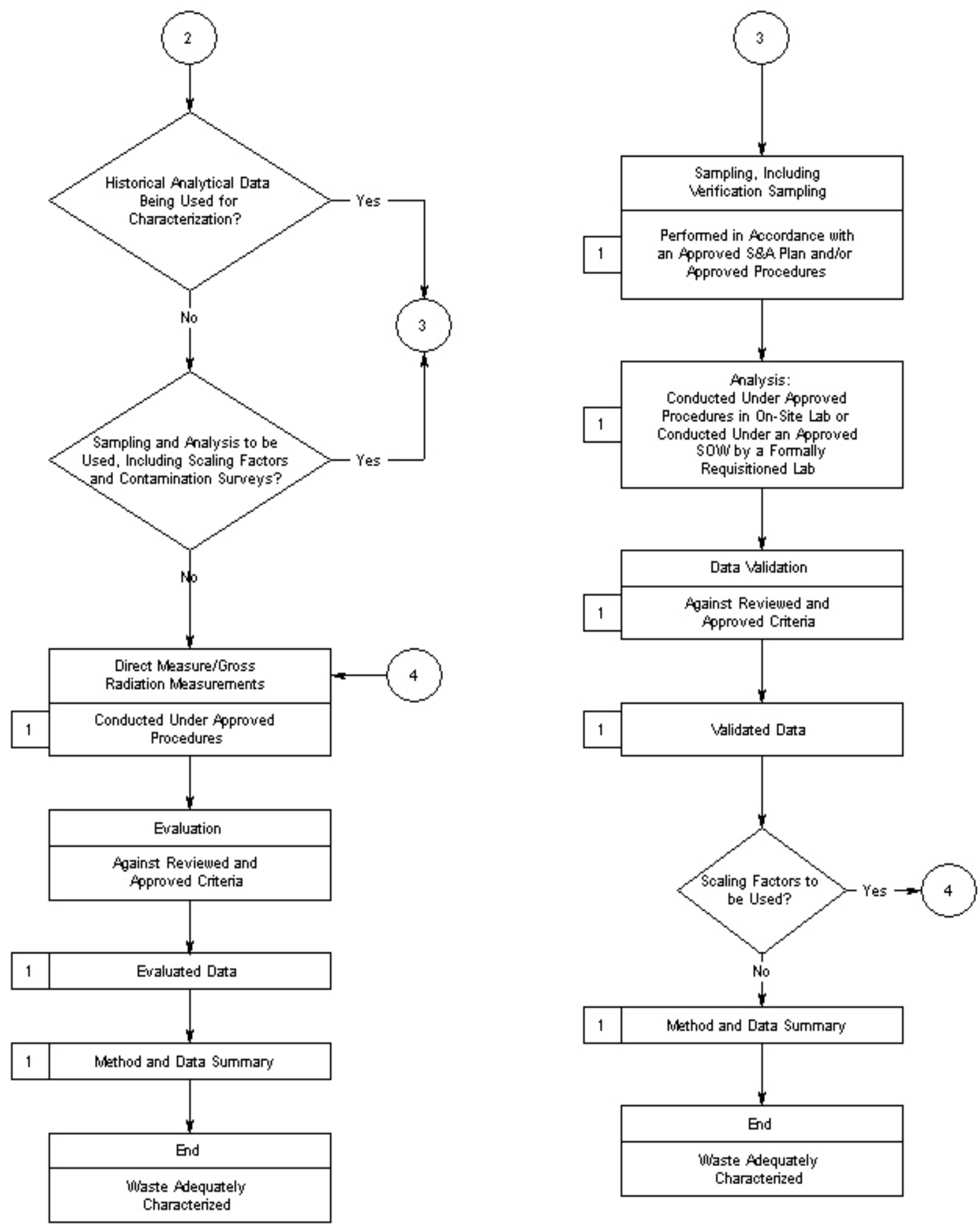

NOTE: Historical analytical data used for characterization should be verified through controlled analytical methods.

Documents Should Be Referenced in the Waste Profile 


\section{E.7 Fissile Material Limits}

The quantity of fissile material in a waste package acceptable for disposal shall be demonstrated to meet any of the following:

1. Does not exceed $15 \mathrm{~g}$ of ${ }^{2.35} \mathrm{U}$ Fissile Gram Equivalence (FGE) per package. ${ }^{4.10}$ FGE is determined by completing Table E.3.

2. Does not exceed 350 grams of ${ }^{235} U$ FGE per package nor does it exceed $2 \mathrm{~g}$ of ${ }^{235} \mathrm{U}$ FGE per kilogram of waste (mass of the package is not included in the mass of the waste) (graphite and beryllium must not exceed $1 \%$ by mass of the waste). Both limits must not be exceeded.'

3. Does not exceed the limits and the waste package meets the conditions as specified in Table E.4.

4. Does not exceed the limits and the waste package meets the conditions as specified in Tables E.5 and E.6. ${ }^{7.18}$

Note: Waste containing uranium with an enrichment less than 0.90 percent ${ }^{25} \mathrm{U}$ by weight and those nuclides listed in Table E.3 such that their FGE is 1 percent or less of the tabulated grams of ${ }^{235} \mathrm{U}$ does not provide a fissile material concern.

If the waste does not comply with any of above, then a waste specific nuclear criticality safety evaluation (NCSE) may be necessary for acceptance of the waste. Please contact the RWAP Task Manager for further information on the criteria for performing a NCSE.

If the waste stream contains enriched uranium $\left({ }^{235} \mathrm{U}\right.$ weight percent $\left.\geq 0.90\right),{ }^{233} \mathrm{U},{ }^{239} \mathrm{Pu},{ }^{241} \mathrm{Pu}$, ${ }^{2424 \mathrm{~m}} \mathrm{Am},{ }^{243} \mathrm{Cm},{ }^{245} \mathrm{Cm},{ }^{247} \mathrm{Cm},{ }^{249} \mathrm{Cf}$, or ${ }^{251} \mathrm{Cf}$, the ${ }^{235} \mathrm{U}$ FGE and ${ }^{235} \mathrm{U}$ effective enrichment is required to be reported with the profile by completing Table E. 3 for each enrichment range. The waste shall not exceed the total FGE as specified for the effective enrichment. 
Table E.3: Calculation of ${ }^{235} \mathrm{U}$ Fissile Gram Equivalence and

Effective ${ }^{23} \mathbf{U}$ Enrichment for LLW Packages

\begin{tabular}{|c|c|c|c|c|c|c|c|c|}
\hline $\begin{array}{c}\text { Nuclide } \\
\text { (A) }\end{array}$ & $\begin{array}{c}\text { High } \\
\text { Activity } \\
\text { Conc. } \\
\text { (Bq/m3) } \\
\text { (B) }\end{array}$ & $\begin{array}{c}\text { Volume } \\
\text { of } \\
\text { Package } \\
\text { (m3) } \\
\text { (C) }\end{array}$ & $\begin{array}{c}\text { Activity } \\
\text { (Bq) } \\
\text { (D) }\end{array}$ & $\begin{array}{c}\text { Specific } \\
\text { Activity } \\
(\mathbf{B q} / \mathbf{g}) \\
\text { (E) }\end{array}$ & $\begin{array}{c}\text { Mass of } \\
\text { Nuclide } \\
\text { (g) } \\
\text { (D/E=F) }\end{array}$ & $\begin{array}{c}{ }^{235} \mathbf{U} \\
\text { FGE } \\
\text { Factors } \\
\text { (G) }\end{array}$ & $\begin{array}{l}{ }^{235} \mathrm{U} \text { FGE } \\
\left(\mathrm{F}^{*} \mathrm{G}=\mathbf{H}\right)\end{array}$ & $\begin{array}{c}\text { If FGE is > } \\
1 \% \text { of }{ }^{235} \mathrm{U} \\
\text { Mass, then } \\
\text { include } \\
\text { (I) }\end{array}$ \\
\hline${ }^{233} \mathrm{U}$ & & & & $3.6 \mathrm{E}+08$ & & $1.4 \mathrm{E}+00$ & & \\
\hline${ }^{235} \mathrm{U}$ & & & & $8.1 \mathrm{E}+04$ & & $1.0 \mathrm{E}+00$ & & \\
\hline${ }^{239} \mathrm{Pu}$ & & & & $2.3 \mathrm{E}+09$ & & $1.6 \mathrm{E}+00$ & & \\
\hline${ }^{241} \mathrm{Pu}$ & & & & $3.8 \mathrm{E}+12$ & & $3.5 \mathrm{E}+00$ & & \\
\hline${ }^{242 \mathrm{~m}} \mathrm{Am}$ & & & & $3.6 \mathrm{E}+11$ & & $5.4 \mathrm{E}+01$ & & \\
\hline${ }^{243} \mathrm{Cm}$ & & & & $1.9 \mathrm{E}+12$ & & $7.8 \mathrm{E}+00$ & & \\
\hline${ }^{245} \mathrm{Cm}$ & & & & $6.4 \mathrm{E}+09$ & & $2.3 \mathrm{E}+01$ & & \\
\hline${ }^{247} \mathrm{Cm}$ & & & & $3.5 \mathrm{E}+06$ & & $7.8 \mathrm{E}-01$ & & \\
\hline${ }^{249} \mathrm{Cf}$ & & & & $1.5 \mathrm{E}+11$ & & $7.0 \mathrm{E}+01$ & & \\
\hline${ }^{251} \mathrm{Cf}$ & & & & $5.9 \mathrm{E}+10$ & & $1.4 \mathrm{E}+02$ & & \\
\hline \multicolumn{2}{|c|}{$\begin{array}{l}\text { Effective }{ }^{235} \mathrm{U}= \\
\text { Enrichment }\end{array}$} & & $\frac{\text { otal }^{235} \mathrm{U} \text { I }}{\text { Total }}$ & & & & \multirow[t]{2}{*}{$\begin{array}{l}\text { TOTAL } \\
{ }^{235} \text { U FGE }\end{array}$} & \\
\hline \multicolumn{7}{|c|}{ Effective $^{235}$ U Enrichment = } & & \\
\hline
\end{tabular}

Instructions for completing Table E.3 are as follows:

1. Multiply high activity range of the waste stream $\left(\mathrm{Bq} / \mathrm{m}^{3}\right)$ by volume of waste to determine the maximum activity that could be present in a waste package for the nuclides listed above, resulting in $\mathrm{Bq}$ (Column $\mathrm{D})$. For ${ }^{235} \mathrm{U}$, the activity is required to be included only if the ${ }^{235} \mathrm{U}$ enrichment is equal to or greater than 0.90 percent by weight of total $\mathrm{U}$.

2. Divide activity $(\mathrm{Bq})($ Column $\mathrm{D})$ by the specific activity of the nuclide $(\mathrm{Bq} / \mathrm{g})$ (Column E) to determine the mass of the nuclide (Column F).

3. Multiply the mass (g) (Column F) of each nuclide by the ${ }^{235} \mathrm{U}$ FGE factor (Column G) to determine FGE (Column H).

4. If the FGE value is greater than 1 percent of the ${ }^{235} \mathrm{U}$ mass, then include in Column I to determine the total ${ }^{235} \mathrm{U}$ FGE for a waste package.

5. Effective ${ }^{235} \mathrm{U}$ enrichment (weight \%) is calculated by dividing the total ${ }^{235} \mathrm{U}$ FGE by the total mass ( $\mathrm{g}$ ) of uranium and multiplying by 100 . 
Table E.4: $\quad$ Allowable Package Fissile Loadings for Various Package Steel Weights.

\begin{tabular}{|c|c|c|c|c|}
\hline \multirow{2}{*}{$\begin{array}{l}{ }^{235} \mathrm{U} \\
\text { Enrichment } \\
\text { Weight \% }\end{array}$} & \multicolumn{4}{|c|}{ Maximum Grams of ${ }^{235} \mathrm{U}$ per Package } \\
\hline & $\begin{array}{c}35 \text { Pounds } \\
\text { (16 kg) } \\
\text { Steel }\end{array}$ & $\begin{array}{c}50 \text { Pounds } \\
(23 \mathrm{~kg}) \\
\text { Steel }\end{array}$ & $\begin{array}{c}70 \text { Pounds } \\
(32 \mathrm{~kg}) \\
\text { Steel }\end{array}$ & $\begin{array}{c}105 \text { Pounds } \\
(48 \mathrm{~kg}) \\
\text { Steel }\end{array}$ \\
\hline $80-100$ & 54 & 66 & 82 & 103 \\
\hline $60-80$ & 55 & 67 & 83 & 105 \\
\hline $40-60$ & 56 & 68 & 85 & 107 \\
\hline $20-40$ & 60 & 73 & 90 & 110 \\
\hline $15-20$ & 65 & 78 & 95 & 120 \\
\hline $10-15$ & 70 & 83 & 100 & 130 \\
\hline $8-10$ & 75 & 90 & 110 & 140 \\
\hline $7-8$ & 80 & 97 & 120 & 150 \\
\hline $6-7$ & 85 & 104 & 130 & 160 \\
\hline $5-6$ & 90 & 109 & 135 & 170 \\
\hline $4.5-5$ & 100 & 121 & 150 & 190 \\
\hline $4-4.5$ & 105 & 129 & 160 & 200 \\
\hline $3.5-4.0$ & 110 & 136 & 170 & 210 \\
\hline $3.0-3.5$ & 120 & 146 & 180 & 230 \\
\hline $2.5-3.0$ & 140 & 170 & 210 & 270 \\
\hline $2.0-2.5$ & 170 & 209 & 260 & 330 \\
\hline $1.9-2.0$ & 220 & 271 & 340 & 440 \\
\hline $1.8-1.9$ & 240 & 296 & 370 & 480 \\
\hline $1.7-1.8$ & 260 & 324 & 410 & 530 \\
\hline $1.6-1.7$ & 290 & 363 & 460 & 590 \\
\hline $1.5-1.6$ & 330 & 411 & 520 & 670 \\
\hline $1.4-1.5$ & 380 & 479 & 610 & 790 \\
\hline $1.3-1.4$ & 460 & 580 & 740 & 960 \\
\hline $1.25-1.3$ & 580 & 739 & 950 & 1250 \\
\hline $1.20-1.25$ & 670 & 854 & 1100 & 1460 \\
\hline $1.15-1.20$ & 780 & 1003 & 1300 & 1700 \\
\hline $1.10-1.15$ & 950 & 1220 & 1580 & 2100 \\
\hline $1.07-1.10$ & 1150 & 1514 & 2000 & 2700 \\
\hline $1.04-1.07$ & 1400 & 1829 & 2400 & 3200 \\
\hline $1.02-1.04$ & 1700 & 2214 & 2900 & 4000 \\
\hline $1.00-1.02$ & 2000 & 2643 & 3500 & 4800 \\
\hline $0.99-1.00$ & 2350 & 3143 & 4200 & 5800 \\
\hline $0.98-0.99$ & 2600 & 3500 & 4700 & 6500 \\
\hline $0.97-0.98$ & 3000 & 4029 & 5400 & 7600 \\
\hline $0.96-0.97$ & 3400 & 4600 & 6200 & 8500 \\
\hline $0.95-0.96$ & 3800 & 5171 & 7000 & 10000 \\
\hline$<0.95$ & 4400 & 5943 & 8000 & unlimited \\
\hline
\end{tabular}


Instructions for using Table E.4 are as follows:

1. For LLW that has enrichment exactly at the boundary between two enrichment ranges, the larger fissile mass loading may be used.

2. Linear interpolations between steel weights are allowed. For steel weights in excess of $105 \mathrm{lb}(48 \mathrm{~kg})$, use the fissile mass for $105 \mathrm{lb}(48 \mathrm{~kg})$; do not extrapolate to a larger fissile mass.

3. Table E.4 is not acceptable for LLW containing more than 1 percent beryllium and carbon graphite by package weight.

4. For waste with nuclides found in Table E. 3 of the NTSWAC (other than ${ }^{235} \mathrm{U}$ ) such that their fissile gram equivalence (FGE) exceeds 1 percent of the grams of ${ }^{235} \mathrm{U}$ present in the waste, then these nuclides must be accounted for. To account for these nuclides, an effective enrichment must be calculated as: ${ }^{235} \mathrm{U}$ grams + FGE) divided by Total U and multiplied by 100 percent. The effective enrichment and the sum of the total ${ }^{235} \mathrm{U}$ FGE are determined by completing Table E.3, and they are used to verify compliance with Table E.4.

5. The total weight of steel in a package may include that of all inner drums such as 10-, 15-, and 30-gallon drums inside of a 55-gallon drum, and the outer drum.

6. Mixing drums in an overpack, such as commingling 15-, 30-, and 55-gallon drums in a 4 x 4 x 7 box, is acceptable as long as the individual drums comply with Table E.4 limits.

Low-level waste (LLW) packages meeting the restrictions as specified in Table E.5 and the fissile limits in Table E.6 satisfy the criticality safety criteria specified in Section 3.2.1.

\section{Table E.5: Criticality Safety Restrictions for the Use of the Fissile Limits in Table E.6.}

\begin{tabular}{|c|c|}
\hline Volume of overpack, if used & $>$ nominal 55 gallons (outermost container) \\
\hline Volume of waste container & $\begin{array}{l}55 \text { gallon drum (may contain inner drums } \\
\text { such as a } 10 \text {-gallon container inside a } 30 \text { - } \\
\text { gallon drum, both within the } 55 \text {-gallon } \\
\text { outer drum) }\end{array}$ \\
\hline $\begin{array}{l}\text { Space between 55-gallon drum (waste } \\
\text { container) and inner containers }\end{array}$ & $\begin{array}{l}\text { If filled, the material must be loose, } \\
\text { pourable material (e.g., vermiculite). }\end{array}$ \\
\hline Boron location & Boron must be inside 55-gallon drum. \\
\hline Boron physical properties (natural) & $\approx 20$ atom $\%{ }^{10} \mathrm{~B}, \approx 80$ atom $\%{ }^{11} \mathrm{~B}$ \\
\hline $\begin{array}{l}\text { Boron weight Note: For example, } 12.9 \mathrm{~kg} \\
\text { of } \mathrm{B}_{2} \mathrm{O}_{3} \text { is required to have } 4 \mathrm{~kg} \text { of boron }\end{array}$ & $\begin{array}{l}\geq \text { nominal } 9 \text { pounds }(4 \mathrm{~kg}) \\
\text { Note: the form is not controlled; e.g., } \\
\text { Boraxo, } \mathrm{B}_{4} \mathrm{C} \text {, and Borosilicate glass are all } \\
\text { acceptable, but it } \text { must be loose/pourable. }\end{array}$ \\
\hline Beryllium and graphite by package weight & $\leq 1 \%$ by weight \\
\hline $\begin{array}{l}\text { Maximum hydrogen content of waste as } \\
\text { packed and as received at the NTS }\end{array}$ & $\begin{array}{l}\text { Hydrogen to }{ }^{235} \mathrm{U} \text { atom ratio }(\mathrm{H} / \mathrm{X}) \text { must be } \\
\text { less than } 50 \text {. For example, this limit is } \\
\text { equivalent to a water-to- }{ }^{235} \mathrm{U} \text { mass ratio of } \\
2 \text {. All hydrogenous materials, such as } \\
\text { plastics and cellulose, may be assumed to } \\
\text { be water to determine an equivalent water } \\
\text { mass. That is, } 1 \mathrm{~g} \text { plastics }=1 \mathrm{~g} \text { water. }\end{array}$ \\
\hline Packaging (drum) material and mass & No restrictions. \\
\hline${ }^{235} \mathrm{U}$ limits per package & The values presented in Table E.6. \\
\hline
\end{tabular}


Table E.6: Maximum Grams of ${ }^{235} \mathrm{U}$ as a Function of Enrichment (controls as specified in Table E.5)

\begin{tabular}{|c|c|c|c|}
\hline $\begin{array}{l}{ }^{235} \mathbf{U} \\
\text { Enrichment } \\
(\text { Weight \%) }\end{array}$ & $\begin{array}{r}{ }^{235} \mathbf{U} \\
(\mathrm{g})\end{array}$ & $\begin{array}{l}\quad{ }^{235} \mathbf{U} \\
\text { Enrichment } \\
(\text { Weight \%) }\end{array}$ & $\begin{array}{r}{ }^{235} \mathbf{U} \\
(\mathrm{g})\end{array}$ \\
\hline 0.95 & 9000 & 2.50 & 1810 \\
\hline 0.96 & 8900 & 3.00 & 1650 \\
\hline 0.97 & 8800 & 3.50 & 1554 \\
\hline 0.98 & 8700 & 4.00 & 1485 \\
\hline 0.99 & 8357 & 4.50 & 1436 \\
\hline 1.00 & 7800 & 5.00 & 1400 \\
\hline 1.02 & 7195 & 6.00 & 1225 \\
\hline 1.04 & 6580 & 7.00 & 1179 \\
\hline 1.07 & 5860 & 8.00 & 1125 \\
\hline 1.10 & 5200 & 9.00 & 1072 \\
\hline 1.15 & 4400 & 10.00 & 1028 \\
\hline 1.20 & 3840 & 15.00 & 929 \\
\hline 1.25 & 3500 & 20.00 & 873 \\
\hline 1.30 & 3225 & 30.00 & 814 \\
\hline 1.40 & 2895 & 40.00 & 776 \\
\hline 1.50 & 2650 & 50.00 & 743 \\
\hline 1.60 & 2460 & 60.00 & 720 \\
\hline 1.70 & 2335 & 70.00 & 715 \\
\hline 1.80 & 2215 & 80.00 & 700 \\
\hline 1.90 & 2135 & 90.00 & 690 \\
\hline 2.00 & 2060 & 100.00 & 680 \\
\hline
\end{tabular}

Instructions for using Table E.6 are as follows:

1. For waste with nuclides found in Table E. 3 of the NTSWAC (other than ${ }^{235} \mathrm{U}$ ) such that their fissile gram equivalence (FGE) exceeds 1 percent of the grams of ${ }^{235} \mathrm{U}$ present in the waste, then these nuclides must be accounted for. To account for these nuclides, an effective enrichment must be calculated as: $\left({ }^{235} \mathrm{U}\right.$ grams + FGE) divided by Total U and multiplied by 100 percent. The total ${ }^{235} \mathrm{U}$ FGE and effective ${ }^{235} \mathrm{U}$ enrichment are determined by completing Table E.3 and they are used to verify compliance with Table E.6. 
This page intentionally left blank. 


\section{Appendix F}

\section{Requirements for Intermodal (Roll-Off Boxes) \\ LLW Disposal}


This page intentionally left blank. 


\section{Appendix F - Requirements for Intermodal (Roll-off boxes) LLW Disposal}

Intermodal (roll-off) containers used for the disposal of bulk LLW must meet the following criteria. This criteria is specific to intermodal roll-off containers that will be unloaded and returned to the generator site. This criteria is in addition to the all other NTSWAC requirements.

1) Prohibited Waste Types:
a. Classified material
b. Asbestiform LLW (regulated)
c. MLLW
d. LLHB waste
e. $\mathrm{PCB}$ waste
f. Laboratory trash
g. PPE or combustible materials
h. Fine particulates that could become airborne
i. Gas cylinders, fire extinguishers, aerosol cans (pressurized or not)
j. LLW Beryllium Waste (particulate)
k. Sealed sources

2) Acceptable Waste Types:
a. Soil and gravel
b. Concrete rubble
c. Scrap metal
d. Building rubble
e. Other materials may be acceptable (with prior approval on a case by case basis)

3) Dose rates and Radiological Concerns
a. Dose rates should be less than $5 \mathrm{mR} / \mathrm{hr}$ on contact of the loaded intermodal container.
b. Dose rates must be less than $5 \mathrm{mR} / \mathrm{hr} @ 30 \mathrm{~cm}$ from the waste.
c. Return survey requirements must be clearly communicated to NTS waste operations upon profile submission.

4) Radionuclide Activities
a. Activities must be less than 300 PE-g based on conversions in the NTSWAC.
b. Tritium levels must not exceed $1.00 \mathrm{E}+05 \mathrm{~Bq}$ per intermodal.
c. Thorium or other radon-emanating nuclides may not exceed $1.00 \mathrm{E}+07 \mathrm{~Bq}$ per intermodal total.

5) Size, Weight, and Loading
a. All pieces within container must be reduced to no larger than 3 feet in any dimension.
b. Soils need to be free of scrap metals, large rocks, or debris.
c. Maintain a clearance of at least 18 inches between the top of the waste and the bottom of the top header brace located near the door end of the container.
d. Waste must fit into the intermodal container without wedging into any area of the container.


e. The load must be prepared to prevent movement during transportation and allow the waste to exit under the header and through the rear door with sufficient clearance to prevent jamming.

f. Precautions must be taken during loading to ensure weight is not resting against the door.

6) Weights

a. Weight of intermodal may not exceed 35,000 lbs.

b. Weight must be evenly distributed. Liners - Waste must be placed in a liner within the roll-off container.

7) Liners - Waste must be placed in a liner within the roll-off container

a. Liners must be at least 18 mil for scrap metals and debris

b. Liners must be at least 12 mil for contaminated soils.

c. Liners must be secured around the waste package and cannot be attached to the inside of the intermodal container.

d. Sufficient absorbent material needs to be added to prevent any accumulation of free liquids inside the container, either from precipitation penetration or from condensation.

8) Marking and Labeling

a. All markings and labels not intended for NTS or DOT use must be obliterated.

b. All placards must be removable by the transporter.

9) Container Design

a. No top-hinged tailgate intermodals will be accepted for disposal.

b. There must be no need for NTS Operations to open the top lid of the container for any reason.

c. There must be attachments to secure the door in the open position during offloading.

d. Containers must be at least standard 6' $\times 8^{\prime}$ x 20' ft IP-1 intermodals with hard-lid covers.

10) Off-Loading

Any container that does not off-load successfully will be buried intact. 


\section{Appendix G}

\section{Mixed Waste Forms}


This page intentionally left blank. 


\section{Appendix G - Mixed Waste Forms}

\section{G.1 Pre-Treatment Notification Form for Mixed Waste}

A. Generator Information

1. Company name:

2. Facility address:

3. Generator facility:

4. Primary technical contact:

5. Waste certification official:

email:

Phone:

Fax:

email:

Phone:

Fax:

\section{B. General Waste Stream Information}

1. Waste stream name:

2. Waste stream identification number:

3. Waste generating process description:

4. Estimated volume after treatment:

a. Estimated disposal container counts, container size, and weights:

b. Estimated container dose rates at 30 centimeters $(\mathrm{mR} / \mathrm{hr} @ 30 \mathrm{~cm})$ :

5. Regulatory status. Check all boxes below that describe the regulatory status of the waste stream as generated:

$\square$ Federally regulated (RCRA) hazardous waste (40 CFR 261). List all EPA hazardous waste numbers and applicable regulatory subcategories

$\square$ State regulated hazardous waste codes:

6. Waste composition. Describe the gross composition/component of the waste stream and all hazardous constituents that contribute to any waste codes or LDR treatment standards.

\begin{tabular}{|c|c|c|}
\hline $\begin{array}{c}\text { CAS } \\
\text { Number }\end{array}$ & Chemical Constituent & Waste Component \\
\hline & & \\
\hline & & \\
\hline & & \\
\hline & & \\
\hline & & \\
\hline
\end{tabular}

7. Reportable radionuclides. List the radionuclides that could be reportable in the waste stream:

\begin{tabular}{|c|c|}
\hline Isotope & $\begin{array}{l}\text { Activity } \\
\left(\mathrm{Bq} / \mathrm{m}^{3}\right)\end{array}$ \\
\hline & \\
\hline & \\
\hline & \\
\hline
\end{tabular}

\section{Proposed Treatment Information}

1. Applicable LDR Treatment Standards:

2. Treatment standards:

Concentration Based

Technology Based 
3. Proposed Treatment Facility:

$\square$ On-site Generator procedures:

Commercial Facility name:

Address:

EPA Identification number:

Permit number:

4. DOECAP audit number and date completed of the treatment facility:

5. Treatment process(es) or technology(ies):

6. Proposed final waste form:
$\square$ Solidified/Stabilized
$\square$ Debris
Macroencapsulated
$\square$ Incinerator Ash
$\square$ Soil
$\square$ Other; describe:

7. $\square$ Waste will contain sorbent. What kind? Sorbents used must meet 40 CFR 264.314(e)(1) or (2).

8. Schedule for treatment:

9. Training or PPE necessary for visual inspection of treatment/waste:

Technical Contact Signature:

Date:

WCO Signature:

Date: 


\section{G.2 Mixed Waste Profile Annual Certification Example}

Waste Profile Number:

Waste Profile Revision No.:

Facility:
Expiration Date:

WCO:

The above Mixed Waste Profile (MWP) is about to expire. The NTSWAC requires generators to recertify MWPs on an annual basis. No waste may be shipped under this profile after the expiration date unless it has been recertified or a new waste profile has been submitted and approved.

Please indicate your preference by checking the appropriate box below. If the waste stream has not changed significantly and the waste profile is still accurate, recertify by checking the third box below, providing the additional information requested, signing the certification statement, and returning this form to NNSA/NSO WMD. Upon approval, a letter will be sent which authorizes continued shipment of the waste stream for up to an additional year.

Check the appropriate box:

This waste profile is no longer needed. Please cancel the waste profile.

There have been significant changes to this waste stream. I understand that this waste stream cannot be shipped to the NTS until a revised or new profile is approved. I will revise it or submit a new waste profile.

I want to recertify the waste profile. I have reviewed the revision no. and certify that it is current, complete, and accurate description of the waste stream and the methods employed to ensure that the waste meets the NTSWAC.

If you checked the third box above, answer the following questions to confirm that the waste stream has not changed significantly. Significant changes will require a revision to the waste profile.

\begin{tabular}{|c|c|c|c|}
\hline No & $\square$ & Yes & Has the waste generating process changed? \\
\hline No & $\square$ & Yes & $\begin{array}{l}\text { Have the methods used to perform radiological characterization } \\
\text { changed? }\end{array}$ \\
\hline No & & Yes & $\begin{array}{l}\text { Have the methods used to perform physical/chemical } \\
\text { characterization changed? }\end{array}$ \\
\hline No & L & Yes & Have any of the RCRA or state waste codes changed? \\
\hline No & L & Yes & Has the LDR status (e.g., subcategories, treatment, etc.) changed? \\
\hline No & $\square$ & Yes & $\begin{array}{l}\text { Have there been any other changes to the waste stream that could } \\
\text { affect management of the waste at NTS? }\end{array}$ \\
\hline No & $\square$ & Yes & $\begin{array}{l}\text { Do you have any new waste analysis data that confirms or improves } \\
\text { your waste characterization? }\end{array}$ \\
\hline
\end{tabular}

Provide the volume remaining in the waste stream:

If you checked any "Yes" boxes, please explain below and attach additional sheets as necessary.

Certification: I certify that, to the best of my knowledge, the information provided on this form and any attached documentation is accurate and complete.

WCO Signature:

Date:

Print Name: 
This page intentionally left blank. 
Appendix $\mathbf{H}$

Glossary 
This page intentionally left blank. 


\section{Appendix H - Glossary}

Certified Waste: Waste that has been confirmed to comply with disposal site Waste Acceptance Criteria (WAC) under an approved certification program.

Chelating Agents: Amine polycarboxylic acids (e.g., EDTA, DPTA), hydroxy-carboxylic acids, and polycarboxylic acids (e.g., citric acid, carbolic acid, and gluconic acid).

Chemical Screening: Process in which waste is examined for characteristics such as ignitability, corrosivity, and reactivity.

“Classified Waste”: A term of art, defined for the purposes of the NTSWAC, to mean: low-level radioactive material, including, but not limited to, nuclear weapons components and assemblies designated by the United States Government, pursuant to Executive Order, Statute, or Regulation, that require protection against information or material disclosure for reasons of national security. Such materials include radioactive waste to which access has been limited for national security reasons and cannot be declassified, and that must be managed in accordance with the applicable DOE Orders and DOD Directives.

Controlled Copy: An approved, uniquely numbered document regulated through controlled distribution.

Corrective Action: Measures taken to rectify conditions adverse to quality and, where necessary, to preclude repetition.

Disposal: The emplacement of Low-Level Waste (LLW) or Mixed Waste (MW) in a manner which is considered permanent in that routine recovery is not provided for.

Facility Evaluation: A documented review to evaluate a generator's program to be in compliance with the WAC. Facility evaluations are conducted by Radioactive Waste Acceptance Program (RWAP) personnel in the form of an audit, surveillance, program reviews, or a combination of these.

Free Liquid: Liquids which readily separate from the solid portion of the waste including liquid that has been released during handling, storage, or transportation.

Generator: An individual, facility, corporation, government agency, or other institution that offers waste material for certification, treatment, storage, or disposal.

Hazardous Waste Component: Waste identified or listed in Title 40 Code of Federal Regulations (CFR) 261, or that otherwise meets the Resource Conservation and Recovery Act (RCRA) definition of hazardous, or waste identified by applicable state-of-generation hazardous waste regulations.

Incompatible Waste: Waste type that might react adversely with its containment materials or commingled waste as defined in Title 40 CFR 260.10.

Inspection: A planned and documented activity, performed by authorized personnel, to verify that an item, service, or process conforms to specified criteria. 
Item: An all-inclusive term used in place of any of the following: assembly, component, equipment, material, part, structure, or system. The term "item" may also include technical data, documents, computer codes, or samples.

Land Disposal Restricted (LDR) Waste: Waste that is prohibited from land disposal in accordance with Title 40 CFR 268.

Low-Level Waste: Low-level radioactive waste is radioactive waste that is not high-level radioactive waste, spent nuclear fuel, transuranic waste, by product material (as defined in section 11e.(2) of the Atomic Energy Act of 1954, as amended), or naturally occurring radioactive material. Small quantities of 11e.(2) byproduct material and naturally occurring radioactive material may be managed as low-level waste provided they can be managed to meet the requirements for low-level waste disposal (DOE M 435.1-1, Section IV.B.(4)). Test specimens of fissionable material irradiated for research and development only, and not for the production of power or plutonium, may be classified as LLW, provided the concentration of TRU does not exceed $100 \mathrm{nCi} / \mathrm{g}$.

Mixed Waste: Waste containing both radioactive and hazardous components as defined by the Atomic Energy Act of 1954 (as amended) and the RCRA. MW must meet the LDRs as listed in Title 40 CFR 268.

Nonconformance: A deficiency in characteristic, documentation, or procedure that renders the quality of an item or activity unacceptable or indeterminate.

Package: The packaging, together with its contents; a container (usually a drum or box) of waste in final form for disposal, one or more of which may constitute a shipment.

Packaging: The assembly of components necessary to ensure compliance with U.S. Department of Transportation (DOT), U.S. Environmental Protection Agency (EPA), and NNSA/NSO requirements. It may consist of one or more receptacles, absorbent materials, radiation shielding, spacing structures, thermal insulation, and devices for cooling or absorbing mechanical shocks. The conveyance, tie-down system, and auxiliary equipment may sometimes be designated as part of the packaging.

Parcel: An individual component, item, or bag of waste, two or more of which may make up a package.

Pyrophoric Material: A material which, under normal conditions, is liable to cause fires through friction, retain heat from processing, or which can be ignited readily and, when ignited, burns so vigorously and persistently as to create serious transportation, handling, or disposal hazards.

Qualification: The characteristics or abilities gained through education, training, or experience, as measured against established requirements, such as standards or tests that qualify an individual to perform a required function.

Qualified: Having complied with the specific requirements or precedent conditions.

Quality Assurance: All those planned and systematic actions necessary to provide adequate confidence that a structure, system, or component will perform satisfactorily in service.

Radioactive Waste: Solid, liquid, or gaseous material that contains radioactive nuclides regulated under the Atomic Energy Act of 1954 (as amended). 
Radioactive Waste Management Site: Designated locations where radioactive waste handling, storage, or disposal operations are conducted. Real-Time Radiography: X-ray unit used to examine waste packages.

Removable Contamination: Removable radioactive material on the package surface or shipping vehicle.

Stabilization: A technique that limits the solubility and mobility of waste constituents by bonding or chemical reaction with the stabilizing material.

Sealed Sources: Sources where the radioactive material is contained in a sealed capsule, sealed between layers of non-radioactive material, or firmly fixed to a nonradioactive surface by electroplating or other means. The confining barrier prevents dispersion of the radioactive material under normal and most accidental conditions related to the use of the source.

Storage: For the purposes of the NTSWAC, storage refers to the long-term management of "classified waste."

Solidification: A technique that limits the solubility and mobility of waste constituents by immobilization through physical means.

Supplier: Any individual or organization who furnishes items or services in accordance with a procurement document. An all-inclusive term used in place of any of the following: vendor, seller, contractor, subcontractor, fabricator, consultant, and their subtier levels.

Tamper-Indicating Devices: Devices that may be used on containers and that, because of their uniqueness in design or structure, reveal violations of containment integrity.

Treatment: Any method, technique, or process designed to change the physical or chemical character of waste to render it less hazardous; safer to transport, store, or dispose; or reduced in volume. Five basic treatments are (a) volume reduction, (b) immobilization of radioactive/hazardous components, (c) change of composition, (d) removal of radioactive or hazardous components from the waste, and (e) solidification of liquids.

Uniform Hazardous Waste Manifest: The shipping document EPA Form 8700-22 originated and signed by the generator in accordance with the instructions included in the Appendix to Title 40 CFR 262.

Verification Sampling: A NNSA/NSO program that confirms the accuracy and precision of a generator's analytical data by obtaining split samples of the waste from the generator, and having them analyzed.

Waste Characterization: Determination of the physical, chemical, or radiological properties of waste.

Waste Stream: A waste or group of wastes from a process or a facility with similar physical, chemical, and radiological properties. 
This page intentionally left blank. 


\section{References}

\section{Title 10 - Energy}

$\begin{array}{ll}1.1 & \text { 10 CFR 61.56(a)(5) } \\ 1.2 & \text { 10 CFR 61.56(a)(8) } \\ 1.3 & \text { 10 CFR 850.32(b) } \\ 1.4 & \text { 10 CFR 850.38 } \\ 1.5 & \text { 10 CFR 835, Appendix D }\end{array}$

Title 29 - Labor

2.129 CFR $1910.178(0)(2)$

\section{Title 40 - Protection of Environment}

$\begin{array}{ll}3.1 & \text { 40 CFR 260.11(a) } \\ 3.2 & \text { 40 CFR 261 } \\ 3.3 & \text { 40 CFR 261.1(a) } \\ 3.4 & \text { 40 CFR 262.20(a) } \\ 3.5 & \text { 40 CFR 262.32(b) } \\ 3.6 & \text { 40 CFR 264.170 - .179 } \\ 3.7 & 40 \text { CFR 264.314(d) } \\ 3.8 & \text { 40 CFR 265.177 } \\ 3.9 & 40 \text { CFR 265.314 } \\ 3.10 & 40 \text { CFR 265.315 } \\ 3.11 & 40 \text { CFR 268 } \\ 3.12 & 40 \text { CFR 268.7 } \\ 3.13 & 40 \text { CFR 761.50(b)(7)(ii) } \\ 3.14 & 40 \text { CFR 761.60(b)(4) } \\ 3.15 & 40 \text { CFR 761.60(b)(6)(ii)(A) } \\ 3.16 & 40 \text { CFR 761.61(a)(5)(i)(B)(2)(ii) } \\ 3.17 & 40 \text { CFR 761.61(a)(5)(v)(A) } \\ 3.18 & 40 \text { CFR 761.62(b)(1)(i and ii) } \\ 3.19 & 40 \text { CFR 761.64(b)(2) } \\ 3.20 & 40 \text { CFR 761.79(g)(6) } \\ 3.21 & 40 \text { CFR 761.62(b)(4)(I) } \\ 3.22 & 40 \text { CFR 761.40 }\end{array}$


Title 49 - Transportation

$\begin{array}{ll}4.1 & \text { 49 CFR 172.200 - .205 } \\ 4.2 & \text { 49 CFR 172 Subparts D and E } \\ 4.3 & \text { 49 CFR 172.310 } \\ 4.4 & \text { 49 CFR } 173.410 \\ 4.5 & 49 \text { CFR } 173.24 \\ 4.6 & 49 \text { CFR } 173.423 \\ 4.7 & 49 \text { CFR } 173.427 \\ 4.8 & 49 \text { CFR } 173.427(a)(6)(i i) \\ 4.9 & 49 \text { CFR } 397.101 \\ 4.10 & 49 \text { CFR } 173.453\end{array}$

Nevada Administrative Code (NAC)

$\begin{array}{ll}5.1 & \text { NAC 444.971(1) } \\ 5.2 & \text { NAC 444.971(2) } \\ 5.3 & \text { NAC 444.8565(2)(b) } \\ 5.4 & \text { NAC 444.8632 }\end{array}$

\section{DOE Orders}

DOE Order 420.1, "Facility Safety"
$6.1 \quad 420.14 .3 .2$
$6.2 \quad 420.14 .3 .3$

DOE Order 474.1, “Control and Accountability of Nuclear Materials" DOE Manual M 474.1-1 “Control and Accountability of Nuclear Materials”

6.3 474.1-1 A II. 5(a)(2)

\section{DOE Order 435.1, "Radioactive Waste Management”} DOE Manual M 435.1-1 "Radioactive Waste Management"
$6.4 \quad 435.1-1$ Attachment 2, 49
$6.5 \quad 435.1-1$ III. A
$6.6 \quad 435.1-1$ IV. G(1)
6.7 435.1-1 IV. G(1)(a)
6.8 435.1-1 IV. G(1)(b)
6.9 435.1-1 IV. G(1)(c)
6.10 435.1-1 IV. G(1)(d)(1)
6.11 435.1-1 IV. G(1)(d)(2)
6.12 435.1-1 IV. G(1)(d)(3)
6.13 435.1-1 IV. G(1)(d)(4) 


$\begin{array}{ll}6.14 & 435.1-1 \mathrm{IV} . \mathrm{G}(1)(\mathrm{d})(5) \\ 6.15 & 435.1-1 \mathrm{IV} . \mathrm{G}(2) \\ 6.16 & 435.1-1 \mathrm{IV} . \mathrm{I} \\ 6.17 & 435.1-1 \mathrm{IV} . \mathrm{I}(1) \\ 6.18 & 435.1-1 \mathrm{IV} . \mathrm{I}(2) \\ 6.19 & 435.1-1 \mathrm{IV} . \mathrm{I}(2)(\mathrm{b} \\ 6.20 & 435.1-1 \mathrm{IV} . \mathrm{I}(2)(\mathrm{d}) \\ 6.21 & 435.1-1 \mathrm{IV} . \mathrm{J}(2) \\ 6.22 & 435.1-1 \mathrm{IV} . \mathrm{K} \\ 6.23 & 435.1-1 \mathrm{IV} . \mathrm{O}\end{array}$

\section{DOE Order 414.1, “Quality Assurance”}
6.24
$414.14(b)(2)(a)$

\section{Federal Manuals, Policy, and Organizations}

7.1 DOE Hoisting \& Rigging Manual, (DOE-STD-1090-2004)

7.2 State of Nevada Solid Waste Disposal Site Permit (SW1300001, current revision)

7.3 "Position Paper on the Proper Characterization and Disposal of Sealed Radioactive Sources." Revision 2, October 1997

7.4 Memo 9109-35 to Carol A. Shelton from Steve Okosisi, 11-21-1995, "Request for Evaluation of NVO-325 Criteria to Ensure Safe and Compliant Radioactive Waste Disposal Operations."

7.5 NNSA/NSO RWAP

7.6 NNSA/NSO Operations

7.7 "Test Methods for Evaluating Solid Waste, Physical/Chemical Methods," EPA Publication SW-846, Chapter 1, Section 1.0, 12/1996

7.8 Low-Level Waste Licensing Branch, Technical Position on Radioactive Waste Classification, May 1983, Revision 0, Section C.1.c

7.9 NNSA/NSO Performance Assessment

7.10 USEPA "Waste Analysis at Facilities that Generate, Treat, Store, and Dispose of Hazardous Wastes” PB94-463603, OSWER 9938.4-03, April 1994, Section 1.5.2

7.11 "Criticality Safety Plan for Low-Level Waste Disposal at the Nevada Test Site, Bechtel Nevada, L-E10.317.LAA, current version.

7.12 Title 42 USC, Chapter 23, Section 2021.c(b)(2)

7.13 "Position on the Use of Lead Shielding for the Disposal of Low Level Radioactive Waste at the Nevada Test Site," current version.

7.14 DOE/NV letter from Carl P. Gertz, 8/19/1998, "Contamination Release Limits for Radioactive Waste Transport Vehicles."

7.15 T. P. McLaughlin, "Nuclear Criticality Safety Review of Low-Level Waste Disposal at the Nevada Test Site Radioactive Waste Management Sites," CSR-A490.100, August 2002. 
7.16 Bechtel Jacobs Company, "Nuclear Criticality Safety for Emplacement of ORR Waste at the Nevada Test Site, NCSE-MS-NTS1492, Rev. 0, August 2001

7.17 S. G. Vessard and T. P. McLaughlin, "Nuclear Criticality Safety Evaluation of Low Level Waste Disposal at the Nevada Test Site Radioactive Waste Management Sites," CSE-A490.101, August, 2002.

7.18 S. G. Vessard and T. P. McLaughlin, "Nuclear Criticality Safety Evaluation of Low Level Waste Disposal at the Nevada Test Site Radioactive Waste Management Sites," CSE-A490.103, June, 2003

7.19 DOE Hoisting \& Rigging Manual, (DOE-STD-1090-2004) Chapter 14, Section 14.2.6.2

7.20 Memo A490-06-TC-0005 to James B. Zovi from Thomas Collens, May 23, 2006, "Isotopes with No Direct Plutonium Equivalent Conversion Factor in the Nevada Test Site Waste Acceptance Criteria."

\section{NTS Permits and Plans}

8.0 RWAP-P2, RWAP Waste Analysis Plan

8.0 RWAP Procedure, RWAP-03, Waste Generator Approval Process 